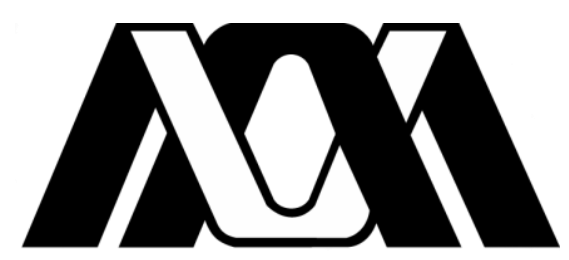

Casa abierta al tiempo

UNIVERSIDAD AUTÓNOMA METROPOLITANA

UNIDAD IZTAPALAPA

DIVISIÓN DE CIENCIAS SOCIALES Y HUMANIDADES

\title{
"La autofiguración del sujeto poético en la lírica de Francisco de Aldana"
}

\author{
Tesis \\ que presenta \\ Jessica Angélica Bátiz del Castillo Quintero \\ Matrícula 2183800902
}

Para obtener el grado de

Maestra en Humanidades (Filología medieval, áurea e hispanoamericana de los siglos XVI al XVIII)

Directora: Mtra. Alma Leticia Mejía González

Jurado: Dr. Marcelo Serafín González García

Dr. Josef Dann Cazés Gryj

Iztapalapa, Ciudad de México, marzo de 2021 


\section{Índice}

$\begin{array}{ll}\text { Introducción } & 3\end{array}$

Capítulo 1 Estado de la cuestión: la obra de Francisco de Aldana 6

$\begin{array}{ll}\text { 1.1 Francisco de Aldana en la crítica y en la literatura } & 8\end{array}$

Capítulo 2 El yo y su construcción en el texto poético 22

2.1 La autofiguración en el marco de las escrituras del yo 22

2.2 El sujeto enunciador lírico $\quad 32$

2.3 El desdoblamiento del sujeto en el espacio: los lugares de la voz $\quad 35$

Capítulo 3 La autofiguración del sujeto lírico desde el tema bélico 46

3.1 La guerra como fuente de honor 46

3.2 El desengaño de la guerra 53

3.3 El repudio de la actividad bélica $\quad 58$

3.4 La ironía del soldado $\quad 62$

3.5 La trascendencia del Imperio Español $\quad 65$

Capítulo 4 La autofiguración del sujeto lírico a partir de la crisis espiritual 72

4.1 La condición humana $\quad 72$

$\begin{array}{ll}\text { 4.2 El desengaño del mundo } & 83\end{array}$

4.3 La contemplación de Dios 99

$\begin{array}{ll}\text { Conclusión } & 106\end{array}$

$\begin{array}{ll}\text { Bibliografía } & 108\end{array}$ 


\section{Introducción}

Situada en una época de transición, la producción poética de Francisco de Aldana transcurre desde los temas amorosos y cortesanos hasta la reflexión por la existencia y el tiempo. Entre el amplio panorama que encontramos en su poesía, este trabajo se concentra en el estudio de la construcción del yo lírico desde la autofiguración. Para ello, la investigación se divide en tres instancias: un estado de la cuestión que delimita las vías del análisis, un capítulo teórico que discute la configuración de un sujeto lírico y se propone definir los rasgos del sujeto de la enunciación lírica para rastrear la configuración de un yo autofigural, y dos capítulos analíticos que se desarrollan en torno a dos ejes temáticos: respectivamente bélico y existencial, que muestran un recorrido y evolución del yo de la escritura, y racionalizan la crisis del mismo, cuya trayectoria vital evoluciona desde lo cortesano y lo bélico a una preocupación espiritual y existencial. El corpus comprende los sonetos V, XVIII, XLV, LV, LVI, LVII, LXI, LXII, LXIII, y los poemas XLVI (Carta al Señor Don Bernardino de Mendoza), LXV (Carta para Arias Montano), XLIII (Parto de la virgen), XXXI (Octavas sobre el bien de la vida retirada), XXXVIII (Pocos tercetos a un amigo), LIV (Diálogo entre cabeza y pie), LIX (Octavas al serenísimo señor don Juan de Austria) y LX (Octavas dirigidas al rey don Felipe, nuestro señor).

El corpus elegido permite apreciar diferentes matices en el proceso de autofiguración así como establecer algunas similitudes y diferencias entre cada filiación temática. La vida del poeta y soldado Francisco de Aldana, al ser tematizada en la lírica, juega un papel importante en su configuración. No obstante, es a partir de la noción de autofiguración que se puede comprender el desdoblamiento de la subjetividad en la textualidad. Central al análisis, es una forma de autorrepresentación que aparece en los escritos biográficos de un 
autor, complementando, afianzando o recomponiendo la imagen propia de dicho individuo. Por lo demás, esta noción se inserta dentro de los estudios de autoficción, que se define por el pacto de lectura en el que existen tres identidades que coinciden (el autor, el narrador y el personaje) aunque las modalidades narrativas y los paratextos sean ficcionales. Así el concepto podría entenderse como la figura que un escritor construye de sí mismo en tanto artista, lugar social desde el cual participa en el campo literario, en interacción necesaria con el contexto histórico específico. Por lo demás, posibilita la examinación de la figura del artista en los propios textos poéticos; es decir, la manera en que se suelen condensar imágenes que son proyecciones diseñadas en los textos y ofrecen un camino para comprender ciertas cuestiones: cómo configura un escritor su lugar en la literatura, a saber, su relación con sus contemporáneos, con la tradición literaria, con sus precursores y cómo se percibe a sí mismo, cómo percibe su lugar en la sociedad, con las instituciones políticas y culturales.

El término biografema, neologismo de Roland Barthes, abre la posibilidad de realizar la biografía del autor a través de sus propios textos ficcionales. Se define como una serie de destellos de sentido que conforman la historia del poeta. Esta noción se complementa con las reflexiones de Maurice Blanchot, quien escribe que "un texto, incluso cuando es fragmentario, tiene siempre un centro que lo atrae: centro que no está fijo, sino que se mueve por la presión del texto y por la circunstancias de su composición” (09).

Acercarse a la obra de este poeta implica ubicar su obra en el contexto de los debates literarios y los conflictos políticos de su época. La obra del capitán está enmarcada en el ambiente militar, que habría de influir de forma permanente en su obra, así como del influjo del mundo cultural de la corte de los Medici, de la tradición humanista y la educación renacentista, pero también por la relación espiritual con Arias Montano y quizá con Fray Luis 
de León, enmarcada dentro de la crisis política de España, la Contrarreforma y en definitiva, por el desencanto del mundo que suponen.

En general, aunque cada uno de estos aspectos ha sido estudiado abundantemente, ha ocurrido de forma aislada o supeditando el uno al otro. La propuesta de esta investigación es trascender los intentos críticos que se han limitado a asentar un vínculo entre su pensamiento y obra, casi siempre más en aspectos biográficos, para establecer una relación efectiva entre ambos en el ámbito estético y literario. Así, el objetivo del trabajo sería racionalizar la figura del yo de la escritura que adquiere una complejidad y evoluciona en el lenguaje lírico para presentar subjetividades que exceden a la figura del autor y de su crisis vital: un tejido literario que ilustra un periodo convulsionado de la historia estética, política y social de España. 


\section{Capítulo 1. Estado de la cuestión: la obra de Francisco de Aldana}

Este apartado ofrece un panorama de los estudios aldanescos y una breve delimitación de la historia textual de su obra. La principal fuente textual de la poesía de Aldana es la edición de su hermano Cosme de Aldana, aunque se han encontrado poesías sueltas manuscritas e impresas. La primera parte de la edición de Cosme se publicó en 1589 en Milán, la segunda en Madrid en 1591 y en 1593 también se publican en Madrid todos los poemas encontrados hasta entonces. Nos han llegado únicamente los testimonios que datan del seiscientos y algunas canciones sueltas que se encuentran en la Biblioteca Nacional de Madrid y que se han incorporado en reimpresiones. Todas estuvieron a cargo Cosme de Aldana, y no existieron más que promesas de ediciones posteriores. Desde que Quevedo proyectó una edición depurada de la poesía de Aldana, como señala J. M. Blecua en Historia de la Literatura Española (106), ha quedado pendiente una edición crítica y cuidada de la poesía del capitán.

En la "Introducción" a Poesías castellanas completas, José Lara Garrido cita las noticias de Cosme de Aldana sobre los textos perdidos de su hermano, principalmente en prosa. El esfuerzo de Cosme por describir estas obras es significativo para dar cuenta de la variedad y riqueza de la obra tanto desde el punto de vista formal como del temático, y abre los ejes para las aproximaciones críticas subsecuentes, tanto contemporáneas del autor (como Quevedo y Cervantes), como en el redescubrimiento del poeta en el siglo XIX.

Faltan de las obras del Capitán Francisco de Aldana, perdidas en la guerra, do siempre consigo las traía: una del Santísimo Sacramento, que era como de cincuenta pliegos y en prosa toda. Otra en que trataba de la verdad y de la Fe, casi de otros tantos y asimismo en prosa. Otra de amor, tratado platónicamente. Otra intitulada Ciprignia en diálogo, do fingía cierto retiramiento de caballeros en vida solitaria en la isla de Cipro, en prosa y vario verso. Infinitas otavas sobre el Génesis. Perfeciones de la Virgen Nuestra Señora. Las epístolas de Ovidio 
traducidas en verso suelto. Obras de amor y hermosura a lo sensual. Una obra de Angélica y Medoro de innumerables otavas. Muchos versos en tercetos a varios. Obra de Pattenio y Niso, la cual con otra obra pastoril ambas dos dignísimas y muy largas jura aquí su hermano por cuanto santísimamente puede jurar habérselas visto quemar, y desto ser casusa el precisar poco el cuanto hacía, no pareciéndole bien. Faltan infinitos sonetos, otavas, canciones y de todo género de verso, así a lo espiritual como a lo temporal, de varias materias. Muchas cartas muy doctas sobre varios sujetos, y otras ridículas y llenas de gracias, donaires, y buenos dichos. (109-110)

A partir del valioso trabajo de Carlos Ruiz Silva, Estudios sobre Francisco de Aldana, se puede comprender cómo circularon los manuscritos y trazar una descripción de la recepción contemporánea y póstuma del poeta. No sólo fue valorada su obra (Quevedo, Cervantes y Gil Polo lo mencionan como “divino”), sino su figura paradigmática de soldado y poeta, al servicio del imperio, pero afectado espiritualmente por su experiencia vital en la coyuntura histórica que vivió.

Asimismo, gracias a la tesis doctoral del profesor Elías L. Rivers, se tiene un trabajo inaugural sobre la vida y obra de Francisco de Aldana, muy importante para sistematizar el estudio de su producción literaria. Todos los documentos que sustentan esta tarea biográfica (casi definitiva a falta de nuevo material hasta descubrimientos de poesías sueltas muy recientes) se encuentran en el Archivo General de Simancas. Carlos Ruiz Silva reproduce los facsímiles de ciertas epístolas y documentos para seguir las líneas que marca el hispanista norteamericano, pues éstas son fundamentales para establecer cualquier tipo de ordenación de su obra, la filiación temática de sus poemas y conocer las condiciones materiales de producción de su poesía. Desde las noticias de Cosme, la clave interpretativa de la obra del capitán Aldana está enmarcada en el ambiente militar, que habría de influir de forma permanente en su obra, así como del influjo del mundo cultural de la corte de los Medici, de la tradición humanista y la educación renacentista, pero también por la relación espiritual con 
Arias Montano y quizá con Fray Luis de León, enmarcada dentro de la crisis política de España y la Contrarreforma.

Elías L. Rivers considera ciertos documentos que ayudan a enmarcar de primera fuente el mundo político de Aldana ${ }^{1}$. El conocimiento de éstos permitió relacionar las motivaciones de buena parte de su obra y la filiación de ciertas partes de su producción poética. De gran interés sería su epístola al Rey Felipe II, ya que contiene los hitos biográficos del poeta escritos por sí mismo. Por otro lado, el intercambio temprano con Cosme nos permite conocer cuánto añoraba su idílica vida florentina, el tiempo con sus amigos y el estudio del humanismo. Serían documentos sine qua non para identificar temática y estructuralmente esta primera parte de su poesía, ya amorosa, ya idealizada, perfectamente acorde con la sensibilidad del humanismo renacentista. La última parte de su obra, incluyendo la famosa epístola a Arias Montano, se sitúa en un momento completamente diferente, y nos anuncia formas y sensibilidades mucho más propias del manierismo.

\subsection{Francisco de Aldana en la crítica y la literatura}

El olvido del poeta en la modernidad no corresponde a la buena estima de sus contemporáneos. Gil Polo, Lope, Cervantes y Quevedo han dejado en sus obras el nombre

\footnotetext{
${ }^{1}$ Me refiero a los siguientes: Carta del Gobernador General de los Países Bajos, Luis Requesens, fechada en Bruselas el 21 de abril de 1579. Archivo General de Simancas. Estado, legajo 559, folio 33.

Carta escrita por Aldana a Felipe II el 15 de septiembre de 1577. Es una epístola autobiográfica. Archivo General de Simancas. Guerra Antigua, leg. 82, folio 156.

Carta del poeta a don Gabriel deZayas, secretario del Consejo de Estado en la que narra su encuentro con el Rey de Portugal Sebastián. Archivo General de Simancas. Estado, leg. 394, fol. 84.

Carta autógrafa del Rey don Sebastián a su tío Felipe II. Archivo General de Simancas. Estado, leg. 394, fol. 235.

Carta de Juan de Silva a Felipe II, fechada el 6 de agosto de 1577. Archivo General de Simancas, leg. 394, fols. 89-90.

Carta de Felipe II a Aldana vencida su resistencia ante las insistentes peticiones del rey de Portugal. Archivo General de Simancas, Estado, leg. 395, fol. 74.
} 
de Aldana, y el estudio de sus obras nos permite consolidar la imagen de un hombre, militar y poeta. La valoración de todos sus contemporáneos se construía no sólo sobre su quehacer literario, sino militar. Gil Polo, en el libro tercero de la Diana enamorada, cuando apenas tenía 27 años, se refiere a él de la siguiente manera: “este es Aldana, el único monarca, / que junto ordena versos y soldados" (vv. 337-338). Cervantes nombra en dos ocasiones a Aldana. La primera en el Libro VI de La Galatea, de 1585, en el que Caliope cita a un grupo de poetas admirados por Cervantes, junto con Boscán, Garcilaso, Castillejo y Torres Naharro:

[...] soy la que ayudó a texer al diuino Ariosto la variada y hermosa tela que compuso; la que en esta patria vuestra tuuo familiar amistad con el agudo Boscan y con el famoso Garcilaso, con el docto(r) y sabio Castillejo y el artificioso Torres Naharro, con cuyos ingenios, y con los frutos dellos, quedó vuestra patria enriquescida y yo satisfecha; yo soy la que moui la pluma del celebrado Aldana. (fol. 317r)

La segunda mención cervantina ocurre en el Viaje del Parnaso, en la "Adjunta al Parnaso": [...] todo buen poeta, aunque no haya compuesto poema heroico, ni sacado al teatro del mundo obras grandes, con cualesquiera, aunque sean pocas, pueda alcanzar renombre de divino, como le alcanzaron Garcilaso de la Vega, Francisco de Figueroa, el capitán Francisco de Aldana y Fernando de Herrera. (fol. 79r)

Francisco de Quevedo en Anacreón Castellano tuvo la intención de publicar sus obras en una edición crítica; Lope de Vega, en el Laurel de Apolo, escribe una silva en torno a la muerte de Aldana y el rey Sebastián (Ruiz 49).

Por otro lado, surgieron obras de teatro en las que se escenificaba la muerte de Aldana y del rey Sebastián, y se reproducían algunas de las epístolas entre el rey Felipe II y el capitánpoeta. Lope compuso la Tragedia del Rey don Sebastián y bautismo del príncipe de Marruecos (que se encuentra en Crónicas y Leyendas dramáticas de España, tomo XII). Posteriormente, Luis Vélez de Guevara escribe la Comedia famosa del Rey don Sebastián 
hacia 1607, conservada en la Biblioteca Nacional de España. En esta obra se escenifica la lectura de las cartas de Aldana a Felipe II y al Duque de Alba. Una tercera obra teatral es La gran Comedia del Rey don Sebastián de Francisco de Villegas. En el siglo XVII, el erudito Nicolás de Antonio incluye una noticia amplia de Aldana en Biblioteca Hispana Nova, en el tomo I, e incluye la relación de las obras perdidas a partir del testimonio de Cosme de Aldana (Ruiz 60-61).

Hasta el Romanticismo, Juan Nicolás Böhl de Faber incluyó cuatro sonetos (XIII, XVII, XXXVI y XXXVII), la "Epístola para Arias Montano” y las “Octavas al Rey don Felipe”, en Floresta de rimas antiguas castellanas de 1821 y Aldana llegó a manos de críticos germanos y anglosajones. Henry Longfellow tradujo el soneto XXXVI y XXXVII, y Firedrich Hoffmann al alemán los sonetos II, XIII, XVII y XXXVII (Ruiz 63).

De los críticos españoles del s. XIX, Adolfo de Castro no valora positivamente a Aldana en Poetas líricos de los siglos XVI y XVII (Ruiz 64). Por otro lado, la valoración de Menéndez y Pelayo evoluciona en tres momentos: en 1877 propone al poeta como un hombre de altos pensamientos pero versificador escabroso (Horacio en España 78); en 1881 valora muy positivamente la "Epístola para Arias Montano":

Recuerdo, a propósito de esta distinción, unos tercetos, tan ricos de estilo como profundos en la idea, de un olvidado poeta del siglo XVI, a quien no con entera injusticia llamaron sus contemporáneos el Divino; porque si es cierto que suele versificar dura y escabrosamente, también lo es que piensa tan alto como pocos. Hablo del capitán Francisco de Aldana, natural de Tortosa, muerto heroicamente en la jornada de África con el rey D. Sebastián. No os pesará oír lo que pensaba de la inmersión del alma en Dios, y veréis cuán graciosas y adecuadas comparaciones se le ocurren para vestir de forma poética el intangible pensamiento. (Estudios y discursos de crítica histórica y literaria, tomo II 91) 
Por último, en 1884 en Historia de las ideas estéticas en España, propone a Aldana como platónico, místico y como un gran poeta olvidado por la historia literaria (Tomo II 5153).

Comenzando en el siglo XX, el poeta Dámaso Alonso apenas mencionó a Francisco de Aldana en sus Estudios y ensayos, así como Rafael Lapesa, quien lo cita únicamente en Poetas del siglo XVI. J. M. Blecua incluye tres de sus sonetos en Floresta de lírica española. José María de Cossío editó la "Epístola para Arias Montano" en la revista Cruz y Raya, y cuatro muestras de la obra bajo el epígrafe "Imperio y milicia”. Luis Rosales y Luis Vivanco, así como Ricardo de Arco y Garay, defendieron su vida militar en Poesía heroica del Imperio y en La idea de Imperio en la política y la literatura española, respectivamente. Ambas publicaciones corresponden a la posguerra civil española y para Ruiz Silva, su objetivo es "tender un puente de continuidad ideológica entre el s. XVI y los primeros años del franquismo" (Ruiz 74).

En seguida se tendría que mencionar el trabajo de los hispanistas no españoles que han contribuido a la edición y los estudios sobre Aldana. En los años treinta del pasado siglo surgen los trabajos de J. P. W. Crawford, Elías L. Rivers, Karl Vossler, Otis R. Green y Alfredo Lefebvre. Como se ha enfatizado, el estudio paradigmático es el de Rivers, pero en conjunto, todos estos estudios han sido la más importante contribución para el conocimiento del poeta antes de Lara Garrido, y los estudios se publican en revistas como Hispanic Review. J. P. Crawford publicó un estudio biográfico en 1939 titulado "Francisco de Aldana: A Neglected Poet of the Golden Age in Spain”. Karl Vossler se ocupa de Aldana en dos libros: Poesie der Einsamkeit in Spanien, traducido al castellano con los títulos La soledad en la poesía española y Poesía de la soledad en España. En este estudio medita sobre la soledad en la literatura española desde la lírica medieval. 
Antonio Rodríguez-Moñino es el primer hispanista español que intenta estudiar la obra de Aldana en su integridad. Publica en 1946 el Epistolario poético completo, por el Consejo Superior de Investigaciones Científicas en Madrid, documento que constituye el primer estudio biográfico y crítico en español. Entre algunas consideraciones críticas del estudio preliminar se encuentra lo siguiente:

Lo fundamental de Aldana no es la vida exterior, sino la íntima. Leyendo su obra poética, henchida de sutilezas y distingos, de amplias reflexiones, de laberintos teológicos, de panoramas interiores llenos de detalle y color, se adquiere el convencimiento pleno de que el escritor es ante todo un hombre de contemplación y de emoción filosófico-religiosa. (67)

Es interesante que este estudio se contrapone a todas las lecturas que han buscado establecer únicamente la vida exterior y militar del poeta con su producción artística. No obstante, en los poemas de corte "heroico" (como las “Octavas dirigidas al rey don Felipe"), se vuelve a caer en la afirmación de un militarismo imperialista del poeta, como los críticos españoles anteriores. Pedro de Lorenzo sigue la línea de Rodríguez-Moñino y publica dos artículos de divulgación: "La razón del Capitán Aldana” y “Geografía imperial de Francisco de Aldana".

Hasta 1948, el poeta Luis Cernuda publica “Tres poetas metafísicos” (en Bulletin of Spanish Studies y posteriormente recogido en el libro de 1971, Poesía y literatura, de Seix Barral). Cernuda rescata el espíritu místico y resalta la lucha entre la realidad desgarradora y el deseo amoroso y contemplativo, que es la contradicción angular desde los estudios de Rivers.

En 1953, el Consejo Superior de Investigaciones Científicas, a través del Instituto Miguel de Cervantes, publica por primera vez desde el siglo XVI, la edición de las obras 
completas de Aldana; no obstante, reproduce la de Cosme, con todos sus errores, y carece de una edición crítica.

Hasta 1957, Elías Rivers proporciona la mejor edición en una antología de la poesía de Francisco de Aldana, publicada por la colección Clásicos castellanos, en Madrid. Asimismo, en 1952 publica un artículo sobre un poema que había sido atribuido a Fray Luis: “A New Manuscript of a Poem hitherto attributed to Fray Luis de León” y en 1953 un artículo biográfico "New Biographical Data on Francisco de Aldana".

Antonio Gallego Morell estudia la fábula mitológica de Aldana en El mito de Faetón en la Literatura Española, de 1961. Es importante desde el punto de vista que pone en relación a Aldana con otros poetas y dramaturgos y lo inserta en la tradición de la literatura española del Siglo de Oro. Otro crítico que ha estudiado este poema mitológico es José María de Cossío en su libro Fábulas mitológicas en España publicado por Espasa-Calpe. También presta atención a otros poemas de carácter mitológico (como las Fábulas de Venus y Marte, Hércules y Onfala, y Europa y Júpiter).

Terminando la segunda década del siglo XXI quedan lejos los primero intentos de hacer justicia a la obra poética de Francisco de Aldana, que había sido olvidada por la crítica hasta finales del siglo XIX y principios del siglo XX. Fue Marcelino Menéndez y Pelayo quien lo incluyó en el canon de la poesía española y más tarde, en 1948, el poeta sevillano Luis Cernuda. Quizá el trabajo ya lejano del hispanista Elías L. Rivers, Francisco de Aldana, el divino capitán, publicado en 1956 en la Revista de Estudios Extremeños, sea la obra crítica fundamental que presenta a un Aldana no sólo como poeta sino como hombre de su tiempo.

Por otro lado, habría que partir de los trabajos de Antonio Rodríguez Moñino, comentarista y bibliófilo, y considerado el primer aldanista. De la misma manera habría que situar el estudio del chileno Alfredo Lefebvre, mucho más específico, pues se centra 
únicamente en la "Carta para Arias Montano". No obstante, los trabajos de Rivers constituyen los mayores aportes para documentar su vida y obra. En 1957, este hispanista norteamericano dispuso la primera edición crítica de poesías de los años 1589, 1591, 1593 y 1595 en las ediciones a cargo del hermano del poeta Cosme. Gracias a Rivers, Francisco de Aldana comenzó a ser accesible para el acercamiento crítico y para restituir su importancia en la poesía del Siglo de Oro.

Joseph Fucilla, hispanista norteamericano, escribe sobre Francisco y Cosme de Aldana en su libro Estudios sobre el petrarquismo en España. Otis H. Green, otro hispanista norteamericano, revisa el estudio de Rivers, El divino capitán, en: “On Francisco de Aldana”. Observations on Dr. Rivers Study of El divino capitán, publicado en la revista Hispanic Review. En suma, la crítica de Green demanda más atención a los elementos propiamente literarios de la obra. Después del trabajo de Rivers, es fundamental considerar el estudio del chileno Alfredo Lefebvre, La poesía del capitán Aldana (1537-1578). Este libro no está disponible y merecería una reedición.

Otis H. Green publicó el artículo “A wedding ‘Introito’ by Francisco de Aldana”, en Hispanic Review, sobre el poema que aparece como "Algunas otavas a lo pastoral del mismo capitán Aldana hechas recitar en unos desposorios de un hermano suyo, de cuyo principio y fin faltan muchísimas". Dedica a Aldana espacio en su obra España y la tradición occidental, dividida en capítulos temáticos. En el capítulo “Amor cortesano y visión platónica” comenta el platonismo de la "Epístola a Galanio”, y de los sonetos “¿Cuál es la causa, mi Damón...?” y “Al cielo". En el capítulo "Fortuna y Hado", incorpora quejas contra el Hado de la "Epístola para Arias Montano”. De mucho interés, y siguiendo líneas anteriormente expuestas, Green expone la expansión geográfica española y su reflejo en literatura. En 1977, Carlos Ruiz Silva 
publicó un artículo sobre el cuarto centenario de la muerte del poeta, antes de sacar a la luz los Estudios sobre Francisco de Aldana.

Entre las primeras grandes aportaciones de Rivers y de Lefebvre, y las ediciones críticas de José Lara Garrido (1984-1985) destacan los trabajos de Green (1958, 1963), Juan Ferraté (1957), Carlos Ruiz Silva (1981), Cuevas (1982), Salstad (1982) y Prieto (1984). De cualquier manera, las aportaciones de José Lara Garrido han sido las más influyentes y de las cuales todo trabajo filológico del poeta debe partir. Se debe destacar el trabajo monográfico de Carlos Ruiz Silva, cuyos Estudios sobre Francisco de Aldana, incluyen un capítulo sobre "Aldana en la crítica y en la literatura" para un repaso de todos los apuntes críticos sobre el poeta desde el siglo XIX hasta 1981. No obstante, omite estudios de Clocchiatti (1963), Alcalá (1973), Bergamín (1973), López Anglada (1979), Salsatad (1979) o Hernando Cuadrado (1981).

Poesías castellanas completas, edición a cargo de José Lara Garrido, aparece como el trabajo más completo de edición crítica. A partir de dicho trabajo, José Lara Garrido propuso la primera edición definitiva de todos estos textos poéticos. Este trabajo publicado por Cátedra, junto con el estudio crítico del hispanista, han sido la más alta contribución a los estudios de Aldana después de Rivers. Propone una nueva ordenación, da cuenta de todos los testimonios en los que se basa su edición y dispone del aparato crítico más exhaustivo. Además, explicita todos los cambios morfológicos, pero respeta aquellos de valor histórico; la ortografía y la puntuación están modernizadas, así como la grafía $(\mathrm{x}=\mathrm{j} ; \mathrm{u}=\mathrm{v} ; \mathrm{ç}=\mathrm{c}, \mathrm{z} \ldots)$. En definitiva, es el trabajo recensior que más justicia le ha hecho no sólo a las poesías del capitán Aldana, sino a la labor editora del hermano Cosme.

El estudio que introduce y declara las intenciones del profesor traza un análisis de la figura del poeta en detrimento de las imágenes arquetípicas y románticas de la vida y obra de 
Aldana. Éste nos advierte contra las imágenes reduccionistas del poeta, a veces originadas en las noticias de su hermano Cosme. Incluso se pronuncia en contra de la visión de Luis Cernuda, quien afirmaba que el poeta trazó y aceptó su propio aniquilamiento en su trayectoria poética. Este enfoque reducía la comprensión de toda la producción poética de Aldana, pues toda lectura conducía únicamente a la valoración de la obra cismática: la “Epístola a Arias Montano”. De tal manera, el resto de la poesía aldanesca constituiría erróneamente un boceto para la epístola, que incorpora todos los rasgos estilísticos e ideológicos de su producción poética, no necesariamente en orden cronológico. Otra imagen reduccionista que nos presenta Lara Garrido es la de Aldana como un emblema que conjuga armas y letras. La crítica que deriva de ésta conduce erróneamente a descifrar su producción poética a partir de los datos de su biografía, que devienen particularmente de la experiencia militar. La crítica anterior había arrojado resultados a partir de una supuesta isocronía, imposible de determinar, entre vida y génesis literaria. Por ello, para Lara Garrido era urgente abandonar el biografismo hipotético que había guiado la organización y valoración crítica de la producción poética. Por el contrario, propone que la única imagen que debe estudiarse es aquella que atañe al “divino” (adjetivo que ya había sido usado por Quevedo y Cervantes entre los contemporáneos del poeta), a partir de la cual se debe buscar el logos que subyace a la expresión poética. Partiendo de que la poesía no supone un mundo mimético, esta clave es la que el crítico propone para emprender la intelección y exégesis de la poesía aldanesca. (Lara Garrido 20). Los apartados de este estudio introductorio: "La escritura integradora: bilingüismo e imitación compuesta"; "Del código petrarquista a la 'humanitas' sensual”; "En la nostalgia del paraíso: variaciones entre la amistad y la acción”; "Las bases metafóricas del misticismo afectivista” exploran la última imagen del “divino” desde el análisis filológico y hermenéutico, marcando las pautas para las investigaciones posteriores. 
Más allá de la aportación crítica de esta edición, es indudable que mejora la puntuación respecto a la edición de Rivers y de Moragón, además de que coteja las variantes de las composiciones con más de un testimonio. Por lo demás, esta edición aporta indudablemente una ordenación que obedece a un orden cronológico aproximado que es consecuente con los datos biográficos, y va más allá de la filiación genérica que resultaría difícil en nuestro poeta. Si bien la edición de Rivers agrupaba las composiciones según su género estrófico, la presentación de Lara Garrido permite observar el proceso evolutivo y la variedad de la creación poética anotada, que facilita leer ciertas composiciones a la luz de Ficino, Leon Hebreo, Varchi, o como reelaborador de las formas renacentistas provenientes de Virgilio, Horacio, Ovidio, Sannazaro, etc.

Los trabajos posteriores a Lara Garrido que se dedicaron a abordar la obra de Aldana son de diversas índoles. Tiene un estudio clave sobre la cuestión editorial y textual, un análisis filológico sobre las “Octavas a Felipe II” de 1988, y también una relectura de la “Carta para Arias Montano" de 1999. En segundo término de importancia, estarían las investigaciones de Dolores González Martínez sobre el estudio de la imagen poética, que iniciaron como artículos $(1988,1989$ y 1991) y posteriormente en una tesis doctoral que está publicada en un libro: La poesía de Francisco de Aldana (1537-1578), Introducción al estudio de la imagen (1995). Eugenia Fosalba, en 1992, estudia las fuentes de los sonetos amatorios en los tratados y en la poesía contemporánea del poeta. Alfredo Mateos Paramio (1993) se ocupa temáticamente de la poesía joven, y busca la fuerza, inocencia y sensualidad del amor humano. Asimismo, Cristina Barbolani (1996) trabaja las octavas que tienen versos españoles y toscanos.

En 1988, el hispanista David Gareth Walters atiende a los dos sonetos religiosos que ya había traducido Henry W. Longfellow, catedrático de Harvard. En 1994, Rosa Navarro 
publica una edición de las poesías de Aldana en Clásicos Universales de Planeta, que es mucho más de carácter de divulgación. El estudio introductorio ofrece un panorama especialmente interesante sobre las epístolas y sus diversificaciones respecto del canon, y está publicado como artículo por la Universidad de Barcelona. A pesar de ser un género bien definido en la literatura española, la autora propone las particularidades de las epístolas aldanescas como la variedad de asuntos y la diferencia de estilo entre las mismas, desde la carta familiar a la carta horaciana en la epístola a Arias Montano. En 1997 María José Martínez López descubre la primera redacción de las “Octavas a Felipe II” que viene acompañada de una dedicatoria al mismo rey. Esto abre una brecha para los estudios textuales y biográficos, además de que se sitúan las octavas en su complejo contexto circunstancial y político.

Giuseppe Mazzocchi (2001) se dedica a lo burlesco en la "Canción a Cristo crucificado". Este estudio se publica en el libro Tiempo de burlas. En torno a la literatura burlesca del siglo de oro. De especial interés es este artículo pues aísla una muestra de la producción poética para integrarla en un campo de problemas literarios más amplio; por otro lado, se le había prestado muy poca atención a las canciones del poeta. A partir de esta última propuesta podría estudiarse con más profundidad el carácter metapoético con el que se resuelve, pues hace una referencia consistente al fracaso del poeta para entregar su canción, con quejas y dolores que inciden en el sujeto que enuncia.

Aproximaciones más recientes son de hispanistas norteamericanos como Dian Fox (2005), Russel P. Sebold (2006), y Susan Byrne que examina la influencia del Corpus hermeticum en Francisco de Aldana, fray Luis de León y San Juan de la Cruz. Además se encuentra la tesis doctoral de Paul Joseph Lennon de la Universidad de Cambridge Beyond Neoplatonism: Love in the Poetry of Francisco de Aldana. 
En 2005, Paolo Pintacuda publica un artículo en el que estudia dos ejemplares desconocidos de las ediciones de Aldana al cuidado de Cosme, que permiten argumentar los lugares de impresión y corregir incluso la opinión de Rivers y Lara Garrido. Valentina Rojas Loa Salazar, de la Universidad Nacional Autónoma de México, estudia las reminiscencias petrarquistas en los versos del poeta. En 2007, Luis Gómez Canseco se dedica a estudiar la contemplación de Aldana junto a Arias Montano. En 2008, Dolores González nuevamente contribuye a estudiar los rasgos estéticos de la epístola a Arias Montano. Ignacio García Aguilar analiza la dispositio editorial de las ediciones de las obras de Aldana para contrarrestar lo que la crítica había observado como manipulaciones editoriales de Cosme. José M. Suárez Diez estudia los sonetos de madurez del poeta poniendo de manifiesto la crisis del petrarquismo y estableciendo conexiones entre el desengaño espiritual de Aldana y la decadencia del Renacimiento.

En 2010, Miguel Ángel de Bunes Ibarra y Abraham Madroñal, a raíz del hallazgo de una carta jocosa, publican una aportación importante al ser la única prosa literaria conservada del autor. Cerrón Puga (2011) examina la huella de Lucrecio en dos sonetos de Aldana. Otros trabajos contemporáneos que se dedican a la figura del poeta son Celso Luján García (2010), Ginés Torres Salinas (2013), Óscar Javier González-Molina (2013), Jimena Gamba Corradine (2015), Mar Martínez Góngora (2015), Paul Joseph Lennon (2015), o Adalid Nievas Rojas (2016).

Del 2013 existe una tesis doctoral de Ginés Torres Salinas: La luz en la poesía española del siglo XVI (Garcilaso, fray Luis, Aldana y Herrera), de la Universidad de Granada. Del 2012, una tesis de licenciatura de Valentina Rojas Loa Salazar: Presencia y análisis de los elementos filosóficos renacentistas en la poesía de Francisco de Aldana, de 
la Universidad Nacional Autónoma de México, dedicada al neoplatonismo y al humanismo principalmente, aunque incluye un capítulo sobre el hermetismo.

Quedan muchas sendas de estudio de la vida y obra de Francisco de Aldana. Cada vez más, su poesía suscita mayor atención filológica e historiográfica, ya sea por su trayectoria vital o por su singularidad poética. Gracias a estos estudios, para finales del siglo XX y principios del XXI ya se podía percibir una imagen renovada del poeta y soldado, una imagen compleja y con muchas aristas. Por un lado se le hacía conocedor de la tradición petrarquista y subversor de ella; por otro lado la sensualidad de sus textos de juventud se asociaba a su formación italiana, al neoplatonismo de Benedetto Varchi, y se ponía de manifiesto su filiación con los modelos de Ariosto y Ovidio. Además, se señalaba su vida militar: soldado, lugarteniente de su padre, capitán en Flandes, sargento junto a Juan de Austria y finalmente junto al rey don Sebastián. Esta parte de su vida ya se relaciona con su vena poética y la dimensión heroica y patriótica (e identitaria) de sus versos. Su religiosidad y ascetismo permea otra parte de su producción poética con rasgos de espiritualidad neoplatónica y cristiana, del misticismo flamenco, así como la moralidad horaciana de la escuela salamantina, congregada en torno a fray Luis de León y Benito Arias Montano. La famosa epístola quizá fue la obra mejor juzgada a finales del pasado siglo como una obra maestra de la lírica del primer Siglo de Oro.

Su producción heteróclita hace difícil encontrar un eje de estudio para su poética como una totalidad. En un mismo corpus coexiste el erotismo, la mitología, guerra, humor, retiro, intelectualidad, contemplación y metafísica, sumada al dominio retórico, cuyo estudio ha dado innumerables resultados: hay efectividad en las anáforas, enumeraciones, antítesis, hipérbaton y encabalgamiento. No sólo desde el punto de vista del contenido, sino desde su singularidad lingüística puede ubicarse a Aldana a caballo entre el Renacimiento y el 
Barroco, y en definitiva, coexisten valoraciones de su obra históricas, estéticas e ideológicas de diversa índole. 


\section{Capítulo 2. El yo y su construcción en el texto poético}

\subsection{La autofiguración en el marco de las escrituras del yo}

Esta investigación se inserta dentro de los estudios de autofiguración y de escrituras del $y o^{2}$ que se han desarrollado considerablemente en los últimos años. Su objetivo, sin embargo, es más amplio y abarca cuestiones relacionadas con los límites y posibilidades que el lenguaje supone para la representación artística, en este caso literaria, y sobre todo para la creación de una figura de autor y de los múltiples gestos del autor que encontramos en el corpus de un poeta cuya escritura es coyuntura de una vida política y militar que termina en una profunda crisis espiritual. De manera más precisa, este trabajo analiza la paradoja de un sujeto lírico que se construye de manera dinámica, y que, sin embargo, subraya constantemente su autoría/autoridad mediante el uso de referencias "autobiográficas" y reflexiones sobre su propia práctica y sobre los límites de su enunciación. El término autofiguración es operativo para analizar la toma de consciencia de sujeto en un contexto de crisis.

La figura de autor presente en las configuraciones líricas debe leerse desde el cruce de dos modalidades principales, que se vinculan con los conceptos de narración y trama estudiados por Paul Ricoeur, particularmente sobre el entramado de rasgos biográficos ficticios (los biografemas) ${ }^{3}$ que no se refieren a un "ser" coherente y acabado de la

\footnotetext{
${ }^{2}$ A partir de ahora empleo las cursivas para identificar la noción de sujeto que rastreo en el análisis.

${ }^{3}$ En el espacio que abre esta experiencia de escritura en la que se afirma paradójica y simultáneamente por un lado, la imposibilidad de decir yo cuando este pronombre ya no remite sino a una ausencia o un exceso, una confusión o un efecto de lenguaje, y, por el otro, el deseo de inscribir en la palabra la singularidad de quien se arriesga en el intento de decirse, surge quizás una nueva necesidad: encontrar un tercer término, una nueva escritura que no afirme ni anule a quien la traza. Escribir, como si lo dicho fuera pronunciado por un personaje de novela, o novelar, fantasear un imaginario que figure no las consistencias, sino las insistencias de un deseo, un gusto, una inflexión singular. Trazar, así, no una biografía sino un conjunto de biografemas múltiples donde
} 
autobiografía "tradicional” pero tampoco a una diseminación total y desarticulada de la figura del autor.

Dicho entramado que configura a este sujeto se basa en el análisis de todos aquellos rasgos que, aun con contradicciones, permiten identificar la conformación de un sujeto (o sujetos) lírico(s). Tras retomar esta discusión teórica, la investigación profundizará sobre algunas particularidades de la poesía lírica; a saber, de un lenguaje como pura potencia para significar y mediar de manera inmediata (es decir, sin la mediación de un narrador) la figura de un sujeto, que es un exceso del relato, en términos de Agamben. Desde este límite precisamente puede ser pensado y representado.

Con respecto al corpus vale destacar la pertenencia del autor a un sistema literario específico, el de la literatura española del primer Siglo de Oro, y a un contexto político que abarca varias décadas. Las particularidades del contexto histórico no se estudiarán más que en la medida en que los poemas así lo requieran y el contexto resulte pertinente. No obstante, es necesario saber que se trata de un periodo bastante convulsionado en la historia peninsular y de gran inestabilidad, pero cuya crisis terminaría resultando muy productiva para las artes y sobre todo para la poesía. Por esta misma razón el análisis del corpus no sigue un parámetro cronológico exacto sino una filiación temática que muestra la compleja figuración del sujeto en diferentes momentos.

Este capítulo debe leerse como discusión teórica por un lado, que plantea el concepto de autofiguración y que discute el tema de la figura del autor en un marco estético-filosófico más amplio en lo que se refiere al problema de la representación/presentación en el lenguaje

lo que se figure sea no lo vivido, sino la vida en lo que ésta tiene de más vital: el cuerpo y el corpus. Gestar una escritura en donde cuerpo y lenguaje se confundan; donde lo que se inscriba y exponga sea la fascinación y la aventura de un sujeto punzado y pulverizado en el 'no-saber' propio del goce (Maccioni 04). 
y en la imagen y del sí-mismo como otro; segundo, como un hilo conductor teórico para los casos de la lírica seleccionada.

Podemos partir de la definición de Georges Gusdorf ${ }^{4}$ para quien:

The author of an autobiography gives himself the job of narrating his own history; what he sets out to do is to reassemble the scattered elements of his individual life and to regroup them in a comprehensive sketch. (35)

Es decir, una definición que implica que el relato es retrospectivo y está articulado desde una persona que reagrupa los elementos "fragmentarios" de su vida individual en una estructura coherente: a saber, en un marco espacio-temporal definido. Sin embargo, los estudios posteriores incluyendo los avances del estructuralismo y postestructuralismo han trabajado sobre los intersticios de esta primera definición. Los textos ficticios pueden incorporar a un yo narrador que puede presentarse como escritor o escritora, o bien, puede haber un narrador mediático que focaliza a un personaje cuya subjetividad se pacta con los rasgos extratextuales de la figura del autor.

Definir el género autobiográfico es problemático. Se debe esbozar una definición que evalúe la incidencia de un sujeto ${ }^{5}$ como efecto de la escritura. Y es esto mismo lo que abre la interrogante sobre el estatuto mismo de dicha escritura para transformar lo "vital" de un escritor en un conjunto archivado de escritura que se significan asincrónicamente ${ }^{6}$.

En definitiva, el problema de esta investigación no es definir los límites de un género autobiográfico, sino cuestionar desde la hibridez y el intersticio que abre el acto lingüístico a la consolidación de un sujeto, y desde estos interrogantes abordar el fenómeno de la

\footnotetext{
${ }^{4}$ Este texto de 1956, "Conditions and Limits of Autobiography", se encuentra en la recopilación que hace el profesor James Olney (1980) en Autobiography: Essays Theoretical and Critical.

${ }^{5}$ En inglés el self y himself.

${ }^{6} \mathrm{Al}$ respecto, la tarea mal valorada de Cosme de Aldana, recuerda la necesidad de recuperar y dar sentido a la producción poética de su hermano.
} 
autofiguración y su relación con la imagen y con la lírica. Ya no sólo implica toda una temporalidad que se intenta plasmar en un género autobiográfico sino la constitución de la identidad de un sujeto que alcanza la imagen final del yo. Más allá de que el creador/ autor escriba de manera autobiográfica o simplemente escriba, hay una lucha o tensión para configurar al sujeto que "enuncia como otro" dentro del acto de escritura. Es una sombra del otro que se desdobla del autor, pero que a su vez le es propia. Para empezar un análisis que dé cuenta de las posibilidades de comprensión que circundan la idea o la posibilidad de una figura de autor en un proceso de autofiguración, suponiendo que es posible, hay que tomar un punto de partida que se distinga de las figuras autorales que produce una autobiografía tradicional.

La autobiografía es siempre relato, y por tanto, re-presentación: volver a contar la vida. Es un relato que nos contamos a nosotros mismos como sujetos. En términos formalistas sería una fábula de la propia vida en la que lo que importa no es tanto el contenido del relato sino las estrategias ficcionales de "autorrepresentación", y por tanto, no la veracidad de lo relatado sino su construcción discursiva. Por ello la autoficción implica asumir la vida como fábula ${ }^{7}$.

Si estas ideas constituyen un punto de partida es porque retoman un tema muy pertinente para la definición de un relato autobiográfico: la relación identidad-relato. Como bien lo explica Eakin:

the selves we have been may seem to us as discrete and separate as the other persons with whom we live our relational lives. This experiential truth points to the fact that our sense of continuous identity is a fiction, the primary fiction of all self-narration. [...] Most autobiographers, however, proclaim the continuous identity of selves early and late, and they do so through the use of the first person, autobiography's most distinctive -if problematic-

\footnotetext{
${ }^{7}$ Luz Aurora Pimentel, en El relato en perspectiva define ampliamente el concepto de relato y fábula (10-12).
} 
generic marker: the "I" speaking in the present -the utterer-is somehow continuous with the "I" acting in the past-the subject of the utterance. This simultaneous double reference of firstperson autobiographical discourse to the present and the past masks the disruptions of identity produced by passing time and memory's limitations. (93)

Ninguna aproximación a lo autobiográfico parece poder eludir el estatuto narrativo. Ahora bien, como la cita de Eakin destaca, en muchas de las autobiografías se presupone la posibilidad (narrativa) de una continuidad relacional entre el sujeto que enuncia (en presente) y el sujeto del enunciado (que sería el protagonista de ciertos hechos ocurridos en el pasado). Esto supone transformar y acomodar el relato para dar una visión "coherente” del yo, la cual subsume las discontinuidades propias la vida de un sujeto. No sólo en la escritura sino en la vida misma hay un vínculo indisoluble entre la narración y la identidad, hasta el punto de poder afirmar que ésta surge desde el relato. De tal manera, el relato es un modo fenomenológico de la experiencia, que se constituye en y desde el lenguaje.

Hasta aquí se ha esbozado la autobiografía y los problemas que la relación relatoidentidad suscitan en dicho discurso. Ahora bien, se debe plantear una caracterización de la autofiguración como una modalidad distinta a la autobiografía pero vinculada con ella. Tomando como punto de partida la definición de Gasparini, la autoficción es uno de los tipos de discurso que conforman lo que llama autonarración:

texte autobiographique et littéraire présentant de nombreux, traits d'oralité, d'innovation formelle, de complexité narrative, de fragmentation, d'altérité, de disparate et d'autocommentaire qui tendent à problématiser le rapport entre l'écriture et l'expérience. (311)

Por lo tanto, la autoficción problematiza toda coherencia que se pretenda totalizante puesto que juega con la innovación formal, la alteridad, los contrastes y diversos niveles metanarrativos. Además, esta modalidad discursiva se identifica con terminología derivada 
de las tipologías narratológicas (como el archigénero de Genette). Esto implica entender que en la autoficción, las incoherencias y la imposibilidad de un relato unificado son el punto principal para reconstruir la identidad del sujeto que nos interesa. El acto autobiográfico consiste en "ausentar al sujeto de la escena de la escritura ocupada totalitariamente por el yo condensado del autor-narrador-personaje" (Rosa 50). El acto autoficcional consistiría no en hacer explícito lo reprimido o subsumido del yo condensado sino en discutir dicha condensación como incapaz de dar cuenta del sujeto enunciador y sobre todo del sujeto textual que es más que nada un sujeto sistematizado y totalizado.

Analizar la autofiguración en un texto lírico supondría no negar la posibilidad de esbozar una identidad del autor o del yo lírico, sino entender la tensión entre la coherencia de ese sujeto y su disolución. Es decir, la representación lingüística de ese sujeto está siempre en crisis pues opera desde la ficción. La autoficción supone que el sujeto narrado (ser del lenguaje) sea un sujeto ficcional en tanto acontece lingüísticamente, y no se puede presuponer una adecuación entre el autor, el narrador y el personaje, entre el sujeto del enunciado y el sujeto de la enunciación, entre un sujeto supuestamente pleno y el sujeto dividido, disperso, diseminado, de la escritura. El problema reside más bien en encontrar los lugares en los que se constituye dicho sujeto. No obstante, no es el lugar del sujeto sino un lugar de sujeto, es decir, un lugar de posibilidad para que diferentes voces irrumpan en ese lugar. Cuando se habla de la "autofiguración del sujeto lírico" en esta tesis, no se pretende una identificación simple y unilateral de la identidad o un esencialismo reduccionista. Desde este punto de vista, el contrapunto entre encontrar un lugar de sujeto y encontrar el lugar del sujeto equivale a la diferencia entre postular un sujeto y un lugar de enunciación flexibles y en continuo devenir, frente a un lugar enunciativo y un sujeto fijos constituidos de antemano. Estamos frente a la diferencia tan central a cierto postestructuralismo, entre un sujeto que se disemina 
(y por ende, su identidad) constantemente en la escritura y que sólo puede apropiarse de cierto lugar enunciativo temporariamente, y un sujeto cuyo lugar y cuya identidad se suponen de antemano y sólo deben ser descubiertas en el texto, distinción que aparecía en la autobiografía pero a favor de una narración cuya construcción, tanto de la identidad como del relato, resultaran más o menos coherentes.

En algunos casos de autofiguración, especialmente en aquellos en los que ésta se repite constantemente hasta convertirse en un eje central del proyecto de escritura como en el caso de Aldana, la separación entre un lugar de sujeto y el lugar del sujeto no se trata de una identidad fija de éste dentro de los textos, que reflejaría necesariamente la identidad del escritor de carne y hueso. En este sentido, si la autofiguración puede entenderse como uno de los procesos más explícitos en su afán diseminador de la identidad del sujeto de la escritura en relación con la identidad del escritor real, no deja de ser un proceso en el que ciertos rasgos del sujeto se repiten constantemente. Por ello, resulta necesario comprender la importancia de la tensión entre la posibilidad de encontrarse con un lugar de sujeto en poemas diferentes y el lugar del sujeto entendido ya no necesariamente como un sujeto "esencial" previo a la escritura sino como un lugar enunciativo compartido por varios textos en diversas circunstancias. Los biografemas, a la par que potenciarían la diseminación del sujeto, también implicarían la presencia de ciertas características, las cuales, al repetirse, conformarían una identidad, incompleta, pero identidad con la cual los sujetos líricos de diversos poemas deberán lidiar para autofigurarse.

La noción de autor es acaso uno de los conceptos más estudiados y cuestionados en la teoría literaria y quizá constituye un eje impulsor de este análisis y de muchos de los estudios que giran en torno a Aldana, como se introdujo en el capítulo anterior. No se pretende trazar una genealogía completa de este concepto, pero es necesario mencionar 
algunos intentos teóricos que han ayudado a repensar esta figura compleja y cambiante y que se encuentra a medio camino entre el escritor real, de carne y hueso, y las voces internas del texto. Robin explica que:

Ante todo, la autoficción es ficción, ser del lenguaje, lo que hace que el sujeto narrado sea un sujeto ficticio en tanto que narrado [...] Ficción, pues no existe nunca adecuación entre el autor, el narrador y el personaje, entre el sujeto del enunciado y el sujeto de la enunciación, entre un sujeto supuestamente pleno y el sujeto dividido, disperso, diseminado, de la escritura. El problema reside más bien en encontrarse un lugar de sujeto que el lugar del sujeto, en constituirse en la escritura un 'efecto-sujeto'. (44)

Ahora bien, se debe cuestionar qué ocurre en aquellos discursos que no poseen narradores justamente porque no implican una narración, un relato (al menos a priori); a saber, el caso de la poesía lírica que supone una temporalidad y una relación con el otro que puede leerse de diversos modos. En los poemas que se analizarán en esta investigación pareciera como si el yo, a la par que buscara desligarse de toda "coherencia biográfica", buscara afianzar una imagen de autor a partir de los biografemas, del retrato de sí mismo, de algunos de los biografemas proyectados en el otro y, mediante la fragmentación y la disolución de la identidad en otros sujetos enunciadores y en destinatarios de la enunciación. Esto es significativo puesto que lo que está en juego en la autofiguración que acontece en nuestro poeta oscila entre la postulación de un yo lírico que parece querer desligarse de una única identidad, pero, al mismo tiempo, un reiterado uso de elementos autobiográficos (desde la aparición del nombre propio del poeta o de algún amigo o familiar hasta la reflexión sobre el sujeto lírico en tanto que poeta que enuncia y escribe el poema en cuestión) que impiden y matizan dicha disolución y que, por el contrario, vuelven a poner en un primer plano al yo lírico y su experiencia vital. 
Para Roland Barthes, en su conocido texto La muerte del autor, la presencia de un autor impide la multiplicidad de niveles de significación. En el caso de Foucault, el interés no radica en afirmar que el autor ha muerto sino en preguntarse qué implica el nombre de un autor y, sobre todo, cómo funciona en relación a un discurso. Para el filósofo francés “discourse that possesses an author's name is not to be immediately consumed and forgotten [...] its status and its manner of reception are regulated by the culture in which it circulates" (235) y es por eso que la función del autor es inicialmente descrita como aquella que caracteriza la existencia y circulación de un cierto discurso dentro de una sociedad. No obstante, la dimensión ficcional de la función autor no es abiertamente discutida por Foucault, y es ésta desde donde surgen las autofiguraciones del sujeto lírico.

Foucault menciona que la crítica literaria moderna ha usado la noción de autor para neutralizar todas las diferencias entre diversos trabajos escritos por la misma persona, pero también para explicar las similitudes; en otras palabras, la "función autor" es usada como un principio de unidad, como una garantía de la misma. Sin embargo, Foucault sostiene que esta manera de concebir al autor no repara demasiado en los elementos dentro del texto y que también lidian con el problema de la autoría y la figuración del autor. Estos elementos son los pronombres personales, los adverbios de tiempo y lugar, y la conjugación verbal, es decir, lo que en pragmática se conoce como deícticos, y que no permiten una fácil identificación del autor de carne y hueso con la voz que enuncia en el texto. Para Foucault la "función autor" no se puede buscar en relación al escritor real ni en relación al narrador ficcional. La “función autor” surge precisamente en la escisión de ambos (239).

Cuando se habla de autofiguración se trata de ver cómo los biografemas se insertan en y afectan el retrato que el sujeto de la enunciación realiza de los demás y de sí mismo a partir de la ocupación de ciertos lugares. Por su parte, Agamben, en "The Author as Gesture”, 
repara, aunque desde otra perspectiva en que: "the author is not dead but to position oneself as an author means occupying the place of a 'dead man.' An author-subject does exist, and yet he is attested to only through the traces of his absence" (64-65). Esta dinámica presenciaausencia resulta útil puesto que lo que Agamben concluye es que el gesto del autor: "guarantees the life only through the irreducible presence of an inexpressive outer edge. Like the mime in his silence and the Harlequin with the lazzo, the author tirelessly returns to enclose himself again within the opening he has created" $(70)^{8}$. Y esta presencia de un límite exterior nunca expresable del todo se vincula con el problema de la subjetividad, problema no menor para el análisis puesto que a la par de la figura de autor, del sujeto lírico como autor de aquello escrito, encontramos el de la configuración de su subjetividad en tanto sujeto que se autorretrata en otros objetos, en otros sujetos o hasta en el propio lenguaje y que retrata a dichos objetos o sujetos aun a riesgo de desaparecer como yo. Escribe Agamben al final de su ensayo:

And just as the author must remain unexpressed in the work while still attesting, in precisely this way, to his own irreducible presence, so must subjectivity show itself and increase its resistance at the point where its apparatuses capture it and put it into play. A subjectivity is produced where the living being, encountering language and putting itself into play in language without reserve, exhibits in a gesture the impossibility of its being reduced to this gesture. (72)

Estos puntos constituyen dos ejes centrales para pensar la figura de autor y los procesos de autofiguración. Por un lado, desde el gesto del autor de presentarse como aquello que da unidad al texto y le otorga su sentido en tanto obra. Por otro, desde el autor como gesto en la escritura que permite la aparición de una subjetividad; es decir, que el gesto del autor es

\footnotetext{
${ }^{8}$ A partir de la mención de la figura del Arlequín de la commedia dell'arte italiana y de su lazzo, lazzo que interrumpe el argumento de la commedia pero que regresa a retomar el hilo del argumento.
} 
ajeno al texto (en el sentido que es exterior y la subjetividad construida dentro del texto excede a la figura del autor), pero que dota de coherencia y unidad.

\subsection{El sujeto enunciador lírico}

El sujeto enunciador lírico es la fuente de emisión del discurso lírico. Parte de la definición y caracterización de lo lírico parte de la especificidad de su modalidad de enunciación: un yo que expresa sus sentimientos. Diana Espinoza abunda en los múltiples acercamientos que la teoría y la crítica literaria han tenido con el género lírico, específicamente aquellos centrados en el sustrato lingüístico del poema o en los recursos retóricos, a partir de lo cual propone un acercamiento que gire en torno al complejo proceso de enunciación lírica (66). Este interés necesariamente retoma la influencia de la pragmática, cuyo alcance metodológico permite poner en el centro de la discusión no al enunciado sino a los sujetos de la emisión. Ahora bien, el enunciado lírico se convierte en un tipo particular de emisión que involucra un emisor y un destinatario.

Para esta investigación, una vez abstraído el concepto de autofiguración y de lugar de sujeto, es de una gran pertinencia la problemática del sujeto enunciador lírico. Espinoza apunta los rasgos genéricos del texto lírico:

La lírica es un género tradicionalmente caracterizado o definido con base en una concepción enunciativa y expresiva. La poesía lírica [...] es el género en el que el yo (muchas veces identificado con el propio autor o poeta) expresa sus sentimientos. (67)

Más aún, la definición abarca una cuestión formal (tal es el empleo del verso), temática y modal, a saber la expresión de sentimientos, y finalmente una cuestión de índole pragmática como es suscitar sentimientos en el receptor. 
Aunque el tema del yo como tema lírico ha sido herencia del movimiento romántico, resulta muy operativo comprender el estatuto elocutivo de dicho pronombre. En la teoría general del lenguaje, el yo es un pronombre que designa a la voz que emite un discurso; a saber, lo que denominamos sujeto enunciador. En la teoría de la enunciación, el sujeto hablante es considerado "una instancia subyacente a todo enunciado, que trasciende la voluntad y la intención de un individuo particular, para transformarse en una figura constituida, moldeada por su propio enunciado existente sólo en el interior de los textos” (Filinich 39).

Desde la perspectiva semiótica designa al sujeto de la enunciación implícito en cualquier enunciado producido, fuera de la experiencia singular de un sujeto empírico. Desde el enfoque pragmático, el yo es una posición, un indicador de la fuente de enunciación. En la literatura y en la lírica éste se despersonaliza en la tercera persona para aproximarse y participar del mundo, que anteriormente se ha identificado como lugar potencialmente ocupado por el sujeto. Otro rasgo que identifica al sujeto enunciador y lo actualiza en tiempo y espacio son los deícticos “aquí” y “ahora”, entre otros. Estas partículas organizan el tránsito del sujeto (en un tiempo) por el espacio de su predicación, y se coloca con anterioridad, simultaneidad o posterioridad respecto a la misma. Una vez determinada la posición del sujeto en el tiempo, la espacialidad solicita la instauración de un punto de vista. Filinch, asimismo retomado por Espinoza señala que:

Toda referencia al espacio implica la instauración de un punto de vista [...] que remite a una posición determinada del sujeto, pero implica también la participación del objeto. La percepción o punto de vista "deictiza un espacio (concreto o abstracto, exterior o interior). Estos espacios, esta dialéctica entre exterior e interior, suele adquirir una dimensión tan importante que por su efecto transforman los estados perceptivos y anímicos del sujeto emisor del discurso. (70-71) 
Un hecho incuestionable es que un poema no es un acto de habla ni un enunciado común puesto por escrito. Espinoza atiende a la especificidad de la literatura en la pragmática, y específicamente del poema lírico dentro de un esquema comunicativo. En tanto que los enunciados literarios no pueden ser analizados y verificados en un marco referencial, y en tanto el sujeto emisor y receptor pertenecen a condiciones contextuales que pueden ser distintas en menor o mayor medida (pues pueden no coincidir en época, por ejemplo), el enunciado se encuentra necesariamente fuera del espacio y el tiempo, y sólo existe en el espacio virtual de la enunciación. Cuando alguien habla en el poema ya no puede ser el poeta, sino una compleja identidad, "ya que la construcción de un sujeto enunciador o la búsqueda de su anulación en diversas máscaras nos hablan, más bien, de una construcción del poeta” (Espinoza 72). De tal manera, lo que interesa es este constructo que se conforma dentro del discurso y que se identifica con "sujeto poético", "voz lírica", o "yo lírico". Comprender el poema en tanto enunciado textual implica, en última instancia, rastrear todas aquellas deictizaciones que dispongan la situación de un hablante potencial que vehicule la dimensión sintáctica y semántica.

Yvancos observa que:

El texto lírico no construye siempre lo que de antemano precisamos saber para situar quién habla, cuándo habla, desde dónde habla y, en el otro lado del canal, quien escucha, cuándo y dónde escucha. Esa creación de espacios de indeterminación enunciativa es un rasgo estructurador y dominante y contribuye a crear un contexto enunciativo que requiere un actitud especial de recepción. (55)

Por tanto, cada poema forma una circunstancia particular de enunciación que está singularizada y actualizada en la reconfiguración de la lectura. El sujeto lírico nunca es el 
mismo, sino que se disemina muchas veces, se contradice, permea los espacios de su predicación, se diluye o se expande.

En la poética de Aldana, el yo dentro del poema se configura en diferentes subjetividades que se pueden agrupar, de manera operativa, en los lugares que deviene dicha voz y el sujeto se convierte en un "efecto" de sí mismo. La complejidad radica en que rastrear dicha subjetivación está condicionada por un haz de cuestiones extratextuales y architextuales. Para los efectos de esta tesis se distinguirán los lugares en los que emerge el sujeto, es decir, partiendo de una perspectiva modal-temática, para profundizar en los aspectos formales y retóricos de cada manifestación particular. El axioma quizá más importante del que se parte, y que depende de las condiciones epistemológicas de nuestra época contemporánea, es que ese yo lírico no es un ente simple, cerrado y concluido, sino que la subjetividad se plantea como un proceso, un irse construyendo a partir del contacto con el mundo. En definitiva, la subjetividad es un devenir, y no debemos comprenderlo como una anulación o disolución, sino como una transformación a partir de una radical alteridad.

\subsection{EI desdoblamiento del sujeto en el espacio: los lugares de la voz}

Tras la discusión teórica que posibilita fincar un análisis sobre el lugar de sujeto y la autofiguración en el texto lírico, surge el problema metodológico para identificar este lugar y la subjetividad que se significa en él. El acto enunciativo supone a un sujeto y su representación se sostiene en la escritura: es, por tanto un constructo que se diferencia del sujeto empírico. El proceso de ficcionalización del yo, es decir, deslindado del sujeto autor, tiene un punto de llegada: una subjetividad arraigada en una ideología y una cultura. Por tanto la voz enunciadora opera en una autoconstrucción hasta alcanzar una representación verbal 
de lo "real"; a saber, la reproducción de la realidad como mecanismo de una cultura y unas pautas discursivas. En este trabajo se observará desde los ejes temáticos bélico y existencial.

En relación a la problemática expuesta, cabe considerar de manera más general la literatura en relación al espacio. Ésta es, por principio, un no-lugar de la existencia, es un espacio que se habita por los sujetos de la lecto-escritura. Por su indeterminación espacial, se convierte en el lugar de la re-presentación y re-creación de todos los lugares posibles. La poesía subsume todos los lugares, es el espacio que habitamos y que nos habita en el acto descodificador de la lectura. Un sujeto siempre habita los confines de un espacio, de manera que se percibe a sí mismo como un ser supeditado a coordenadas espacio-temporales. Ya $\mathrm{Kant}^{9}$ había concebido la espacialidad como un a priori de la sensibilidad, pues esta categoría determina la percepción sensible humana y estructura la forma de conocer del sujeto. El tratamiento del espacio en los textos literarios en la actualidad trasciende la premisa de que es instrumental y únicamente el soporte para la acción. Tampoco es una entidad inmóvil y estática, ni se opone a la movilidad y dinámica del tiempo. Es un espacio verbal mediante el cual surgen las imágenes. Éstas, a su vez, se construyen a través de procedimientos estilísticos y recursos retóricos. Muchos de los poemas líricos no presentan una narración propiamente y se acercan más a algunas conceptualizaciones de la imagen. ${ }^{10}$

La poesía es una forma de aprehender el mundo, de percibirlo y conocerlo, y sobre todo, de recrearlo y dotarlo de sentido. La poesía, así como todo el fenómeno literario, requiere de esta condición cognoscitiva que se materializa de diversas maneras: desde la materialidad de la escritura (pues el uso de ciertas formas métricas conlleva una forma de

\footnotetext{
${ }^{9}$ En Crítica de la facultad de juzgar.

${ }^{10}$ Un detenido análisis de la construcción de estas imágenes en la lírica de Aldana se puede encontrar en la tesis doctoral de Dolores González Martínez: La poesía de Francisco de Aldana (1537-1578).
} 
distribución espacial), los soportes de transmisión, etc., así como la función estructural de los espacios diegéticos y espacios líricos, y finalmente las formas de tematizar el espacio y resignificarlo para trascender su función referencial.

A saber, todas las localizaciones, geográficas y topográficas, los afueras y los adentros materiales o simbólicos, son categorías que sitúan al sujeto poético. Pueden ser el laberinto, la prisión, la isla, el camino, el viaje, el encierro, el campo, la ciudad, etc. y se constituyen en elementos significativos no sólo para la estructura textual, sino como campos ideológicos que permiten una lectura para descodificar su sentido estético, histórico y político. Asimismo, los objetos no sólo implican formas geométricas del mundo exterior, sino que son aprehendidos por su relación subjetiva, es decir, en la medida que implican al sujeto poético. Por otro lado, es indispensable considerar que el hombre es un ser espacial y por lo tanto, fundador de lugares y perspectivas, de manera que "el espacio se configura como lugar significado y ese proceso de significación le brinda una proyección simbólica" (Aínsa 22). Es por esto que el espacio trasciende la precisión geométrica y las dimensiones o coordenadas perceptibles por los sentidos.

Fernando Aínsa, teorizador de los estudios geopoéticos explora los aspectos teóricos que son esenciales para el estudio del espacio en la literatura, partiendo de que los conceptos relacionados al espacio son incoactivos a la condición humana. Sugiere que las representaciones simbólicas que la geometría suscita para describir el espacio a través de una multiplicidad de lenguajes, órdenes y formas, pueden incluir la representación literaria. Nuestras categorías de espacio físico no sintetizan la relación entre naturaleza y cultura, y aún no existe en la cultura occidental una categoría que resuma la relación del sujeto con los fenómenos físicos. No obstante, esta relación es determinante para la creación artística, pues el mundo exterior se reproduce en la imaginación mítica o simbólica del hombre. 
Desde la Física de Aristóteles:

Las partes y especies diferentes de los lugares son el arriba y el abajo, la derecha y la izquierda, el delante y el detrás, términos elaborados a partir de un observador que está de pie, un hombre cuyo punto de vista crea horizontes y perspectivas. (67)

El lugar significa emplazamiento, el locus donde se ha colocado una cosa. Es un adverbio locativo donde indica el lugar desde el cual el mundo se pone en perspectiva y se despliega el campo de la mirada. Allí se colocan marcas en el espacio y en el "aquí momentáneo" del emplazamiento se va construyendo un habitar hecho de apropiaciones, límites y fronteras, lo que es el campo de la propia existencia.

Ahora bien, para el hombre renacentista el espacio había sido una experiencia modelada por la cultura, en la medida en que el espacio euclidiano (cuya geometría tridimensional relacionamos con la geometría clásica) se relativizó a través de símbolos que relacionaban los componentes de la naturaleza y la cultura, el individuo y la sociedad. A saber, la espacialidad en la literatura de la tradición occidental había seguido los modelos de Homero, Virgilo y Ovidio en la presentación de la naturaleza a través de fórmulas retóricas. Este modelo greco-latino primero se extiende a la épica de Edad Media. Posteriormente, se estandariza el espacio en tópicos como el locus amoenus o el beatus ille. Durante el Renacimiento, el tratamiento de lo espacial se apoya en dos aspectos de origen clásico: la valoración bucólica de la Arcadia ideal y la vuelta a la naturaleza; y el menosprecio de la Corte y la alabanza de la aldea. Por ello, los ambientes bucólicos son recurrentes en la literatura de la época, especialmente en la novela pastoril y en la poesía (Capel 117).

Más aún, la literatura ha reelaborado la representación del espacio, al que corresponden percepciones sensoriales diversas, entre la civilización y la barbarie, entre lo sagrado y lo profano, entre el campo y la ciudad, entre el caos y el orden, entre lo político y 
lo natural. Estas antinomias prolongan la dialéctica entre lo finito/infinito, próximo/lejano, alto/bajo, vertical/horizontal, abierto/cerrado, pequeño/grande, continuo/discontinuo, que se expresan estéticamente en la literatura.

También es necesario considerar que la relación entre la existencia humana y el mundo no sólo son de interés filosófico, como las reflexiones de la fenomenología, sino poética, pues la experiencia literaria está vinculada a la experiencia del espacio. Al vincular la noción de experiencia con la del espacio, éste se carga de un significado subjetivo; es decir, la espacialidad externa tiene una espacialidad vivida interiormente, en la subjetividad. Ese es el espacio kantiano, en el que se relativiza el espacio geométrico a priori del sujeto. También lo explica Gaston Bachelard en La poética del espacio al referirse al espacio captado por la imaginación, que ya no tiene categorías absolutas, sino que "es vivido [...] no en su positividad, sino con todas las parcialidades de la imaginación” (17). El espacio que es “espacio vivido" concentra "ser", pues se experimenta desde la subjetividad. Esto implica que la imagen del espacio representado artísticamente se "satura" a través de mecanismos que transforman la percepción exterior en percepción interior, y se convierte en un espacio de la vivencia, de lo sensible, y que permea de significado toda la experiencia del sujeto. Es un espacio en el que el hombre se reconoce y se arraiga, y dota de sentido a toda su experiencia. Por ello, la experiencia del sujeto poético está arraigada y codificada en la representación intencional de un espacio.

La expresión del espacio exterior en la poesía, o más bien, los límites de la experiencia del sujeto poético, se ensanchan y se van indiferenciando del mundo circundante. La espacialidad de la vida humana reivindica un "lugar de encuentro social" propio, donde el hombre "afincado en ese territorio podrá resistir mejor los ataques del mundo, hacerse su vida" (Bollnow 113). De ahí se comprende cómo el lugar es un elemento fundamental de 
toda identidad. Siempre hay un espacio que se proyecta hacia el interior o hacia el exterior, como Bachelard expone: el recinto cerrado de la casa o el abierto de la plaza pública, un espacio de lo íntimo y lo familiar, o un espacio exterior de hostilidad y combate; finalmente un espacio de llegada y de seguridad, o un espacio dinámico del viaje o del camino (33-38). Y es en el lenguaje literario donde términos como camino, escenario, distancia, horizonte, lugar, universo y paisaje se convierten en las figuras privilegiadas para vivir el espacio. La comunicación recíproca entre el exterior y el interior y viceversa, propicia puntos de situación, de unión y separación, de aislamiento y sociabilidad, de atracción y repulsión de los que la creación artística y literaria es puente, pero también lugar de encuentro y síntesis. El umbral, gracias al cual se comunican, participa de la ambigüedad del cruce, es un punto de articulación que no termina de abrirse ni de cerrarse. Estos puntos umbrales mantienen una apertura del sujeto poético y su función es de transición entre lo interior y exterior.

Ahora bien, es la intencionalidad del sujeto la que define toda proyección del espacio y en definitiva, detrás de cualquier abstracción y de cualquier alusión a la espacialidad, se esconde una realidad simbólica. Desde los comienzos de la civilización los seres humanos han conceptualizado el espacio para ordenar y delimitar el espacio propio; para simbolizar todo lo que es conocido y limitar lo que es desconocido y misterioso. La imaginación espacial del hombre también erige una frontera entre lo uno y lo ajeno, y es por ello que toda civilización parte de tomar posesión del espacio circundante. Definitivamente en toda cultura ha existido un enfrentamiento entre lo extraño e irracional de la naturaleza frente al orden civilizatorio y político.

En ese enfrentamiento se empieza por establecer una perspectiva. Una planta, un árbol, la montaña que se recorta en el horizonte, la casa o la choza en la que se vive, se ordenan en un diorama que va integrando el entorno como vivencia y donde se establece una geometría que no determina solamente la configuración de espacios y de formas en una dimensión 
matemática, sino que además le da un sentido, transformando el mundo en universo simbólico. (Aínsa 28)

De manera que todos los objetos que nos rodean han sido objetos de recreación en el orden de la imaginación para reflejar nuestros estados de ánimo. En este caso, el poeta se apropia estéticamente de su alrededor para organizar la realidad en función de una particular perspectiva que busca proyectar una visión sensible e inteligible.

Aínsa elabora sobre el concepto de topofilia, un estado que todo paisaje puede llegar a suscitar. Así, entendemos por topofilia: “el modo como los seres humanos reaccionan a su entorno, la forma en que lo perciben y el valor que le otorgan, donde se funden los conceptos de 《sentimiento》 y de 《lugar»»" (29). Asimismo la palabra es un neologismo útil en la medida en que puede definirse con amplitud para incluir los vínculos afectivos del ser humano con el entorno, lazos que difieren en intensidad, sutileza y modo de expresión (29). Este concepto se conecta con la experiencia individual como una "visión del mundo" o cosmovisión, no sólo personal sino social, ya que está estructurado como sistema simbólico de una cultura y de una visión estética compartida. La poesía es un registro de la subjetividad de un poeta y de su época, y en definitiva de la particular manera en la que el hombre se relaciona con la vida y con el mundo. La obra de Francisco de Aldana, resultado de una trayectoria vital que lo llevó de Italia a Flandes, de la corte al campo de batalla y de ahí a un beatus ille a la orilla del mar, se nos presenta como texto vivo, construido y habitado.

El mundo que media entre el sujeto y la realidad externa se concreta en la intensidad de los espacios. En ese habitar un espacio, en la construcción progresiva del campo de la existencia se aborda el problema de fijar direcciones y sentidos. Construir y habitar concretan el lugar, el topos; al describirlo lo trasciende en logos. Esta dimensión lingüística se traduce en la apertura conceptual a metáforas espaciales. La experiencia del sujeto en el espacio se 
confunde con su representación concreta en expresiones que incluso trascienden el ámbito de la literatura, como "descenso a los infiernos", "estar en las alturas", "clase alta", "salarios bajos" (Aínsa 30).

Iuri Lotman afirma que tras la representación de las cosas y objetos en cuyo ambiente actúan los personajes del texto surge un sistema de relaciones espaciales, la estructura del topos. Además de ser un principio de organización y de distribución de los personajes, esta estructura se presenta en calidad de lenguaje para la expresión de otras relaciones, no espaciales, del texto (283). Para Lotman, la expresión de esas otras relaciones surge cuando el espacio se convierte en modelo de la estructura del espacio del universo. En este nivel de construcción de modelos supratextuales puramente ideológicos, el lenguaje del espacio se revela como uno de los medios fundamentales de construcción, expresión e interpretación de la realidad, ya que refiere a modelos culturales de contenido no espacial. Los modelos históricos y lingüísticos del espacio se convierten en la base organizadora para la construcción de una "imagen del mundo", un modelo ideológico global propio de un tipo de cultura.

En todo caso, el espacio siempre se identifica con y se clasifica en relaciones de poder que se ejercen sobre cierta configuración. El territorio se mide, divide y delimita para controlarlo, a partir de nociones como horizonte, limite, frontera, confín y el espacio vital se abre a nuevas relaciones de dominio, de trasgresión y a formas de diferenciación espacial que pueden ser tanto naturales y espontáneas como artificiales o de dominación.

Zonas fronterizas, recintos sagrados, territorios míticos, fronteras políticas, «fronteras vivas》, «procesos expansivos》, reductos inaccesibles o prohibidos, tierra prometida, practicas fundacionales territoriales, surgen de este proceso de división y fragmentación del espacio y de la idea, tan difícilmente de erradicar del espíritu humano, de «la necesidad de la existencia de limites $\gg$. En este contexto, cobran importancia las funciones de la 
orientación, esos referentes de profunda significación simbólica como son los puntos cardinales - Norte, Sur, Este y Oeste- y los de la situación axial de todo objeto en el espacio: la cruz marcando direcciones que todo observador puede desplegar a partir de su punto de vista y de su localización personal en el espacio. (Aínsa 30)

Este punto de vista tiene que ver con la noción de horizonte, que vehicula la relación entre objeto y sujeto, interior y exterior. El horizonte no es una categoría positiva que pueda ser identificada en un mapa, sino que precisamente se configura a partir de un sujeto y no tiene realidad objetiva. Éste acompaña toda percepción y mezcla el adentro con el afuera mediante el encuentro de una mirada con el mundo exterior. Por un lado, para la fenomenología, el espacio comprende ese intercambio interno y externo, y el horizonte organiza el campo de la percepción; para la experiencia poética, este horizonte resulta inasible con mayor frecuencia, pues el sujeto poético se configura desde este horizonte cambiante y multiforme. De cualquier manera configura y orienta la experiencia poética al dividir el mundo entre cielo y tierra, arriba y abajo, cercano y lejano. Estas direcciones no sólo le otorgan sentido al espacio sino a la existencia misma, y tienen un valor simbólico, por lo que hay que observar de qué manera el poeta vincula esta dimensión al porvenir de su proyecto.

El esfuerzo actual por relativizar y hacer cambiante el espacio de la física, ha existido, por el contrario, desde siempre en la creación literaria. La emergencia del espacio subjetivo se produce espontánea e inevitablemente en un texto poético. Esta invención es una construcción estilística hecha de reiteraciones, alusiones, paralelismos y contrastes que fundan el "lugar", donde los sujetos de la creación verbal no sólo están, sino donde son. El estar determina el ser, y ese espacio es en esencia un conjunto de relaciones entre el individuo, el acontecimiento y el medio. Esta triada se traduce en una semiosis, que 
condiciona el significado de un poema o un conjunto de los mismos. En la poesía se pueden vivir los espaciamientos horizontales, o los vertiginosos espaciamientos verticales; se puede vivir el espacio político, el espacio del refugio, y en definitiva, la yuxtaposición espaciotemporal y la superposición de espacios, de manera que:

Todo espacio que se crea en el espacio del texto instaura una gravitación, precipita y cristaliza sentimientos, comportamientos, gestos y presencias que le otorgan su propia densidad en lo que es la continuidad exterior del espacio mental. (Aínsa 33)

Gracias a autores como Gaston Bachelard en su Poética del espacio, se puede comprender que la dimensión ontológica del espacio integra la dimensión topológica como parte de una comunicación y tránsito natural del exterior al interior y viceversa. Este autor define la noción de topoanálisis definida como: “el estudio psicológico y sistemático de los parajes de nuestra vida íntima" (27). El objetivo del topoanálisis es el estudio del "espacio feliz" o “espacio de la ensoñación” que se correspondería con la imagen de la "casa onírica”. Establece una dialéctica entre el adentro, espacios femeninos de bienestar, albergue y protección del ánima; y el afuera, espacios de hostilidad y exterioridad del ánimus. Todo espacio realmente habitado lleva como esencia la noción de casa (Bachelard 35). La "casa onírica" constituiría el espacio primario en el que el hombre desarrolla el concepto de habitar, no sólo en los espacios materiales, sino también en los espacios que la imaginación crea gracias a las imágenes. La casa se concibe como el espacio poético captado por la imaginación: es vivido, no en su positividad, sino con todas las parcialidades de la imaginación (Bachelard 28). Por lo demás caracteriza distintos tipos de casas: por un lado, la casa de la infancia que habita en la memoria y se corresponde a los recuerdos del pasado y por otro, la casa soñada que se aloja en la imaginación y atañe al futuro, al lugar que se sueña con habitar. Entonces, habitar un espacio implica que el sujeto lo revista de 
significantes para hacerlo reconocible y familiar y así, poder vivirlo subjetivamente. De esta manera y a partir de la confluencia de distintas disciplinas como la retórica, el psicoanálisis y la fenomenología, Bachelard enlaza percepción, imaginación y memoria, para analizar cómo los espacios se instauran a partir de la posición del sujeto respecto al lugar.

Estos modos de organizar el mundo según circunstancias "creativas" que son dinámicas, pero en todo caso subjetivas e interiorizadas, se traducen también en el espacio poético resultado de una tensión, de una escisión y de una disconformidad con lo real. Los impulsos de cambio y de creación de "otra realidad" se traducen en sueños, utopías generadoras de espacios alternativos o de evasión al desencanto, que generan un conjunto de lugares posibles que entrelazan lo mítico, lo natural y lo político. Es este, quizá, el proceso que va del topos al mythos y al logos.

El análisis de los espacios en los que se desdobla el yo lírico son más que un lugar o un entorno: son aspectos que codifican los valores culturales y simbólicos, y permiten que se desarrollen las imágenes líricas. Por otro lado hay un continuo interés del poeta por animar lo inanimado, proyectando al sujeto en el espacio exterior de las cosas. En este modo de proyectar el mundo se puede descubrir que todo gira alrededor del yo y su diseminación en el espacio poético. Ahora bien, también sería fundamental analizar la geometría, que está relacionada con el espacio, pues siempre hay un centro desde el que se enuncian realidades terrenales o metafísicas, o desde el que se personifica la naturaleza en relación al sujeto. 


\section{Capítulo 3. La autofiguración del sujeto lírico desde el tema bélico}

\subsection{La guerra como fuente de honor}

En este eje temático la autofiguración ocurre desde el ámbito individual y social del hombre. Es importante destacar la sociedad en el sentido de conjunto organizado de personas que están presididas por instituciones y las imágenes bélicas que se desprenden de la autofiguración del yo no sólo pertenecen a su ámbito vital sino al cultural y literario, como la literatura espiritual del momento.

Los "Pocos tercetos a un amigo", el poema XXXVIII"11 de la edición de Lara Garrido corresponde a una apología de lo militar, que permea también varios de los sonetos. Rodríguez Moñino propone este texto como una sátira que contrapone la vida cortesana y la vida de un militar (20). Asimismo, Elías Rivers escribe que estos tercetos ponen en evidencia la mentira y la vanidad de la corte en Bruselas (Francisco de Aldana. El divino capitán, 5859). La vida de soldado y su desarrollo humanístico en Flandes son elementos que pudieran estar presentes en los tercetos, pues el poeta construye un discurso para representar a un sujeto que es tanto poeta como soldado.

Estos tercetos se construyen a partir de la dicotomía espacial corte-campo de batalla. Mientras el cortesano lleva una vida regalada, el soldado milita contra el enemigo, pero desde la tradición religiosa castellana, pues el sujeto justifica la necesidad de luchar por las causas de la corona española. Por lo pronto, basta comprender que la partida de Aldana desde Italia a Flandes permite, respectivamente, contrapuntear dos representaciones del sujeto lírico: una vida guerrera más noble que la vida cortesana. El segundo contrapunto será aquel del

\footnotetext{
${ }^{11}$ Lara Garrido lo fecha en julio de 1568 (289). Todos los poemas citados son de esta edición.
} 
transcurso por el espacio encarnizado de la guerra frente al espacio contemplativo, cuyas aristas se construyen a partir de los conocimientos de la vida contemplativa y se verá en los posteriores apartados.

Los 'Pocos tercetos escritos a un amigo' responden al 'humanismo de las armas' que todavía se aprecia en Don Quijote y a la figura del poeta soldado que ejemplifica Garcilaso como ideal de cortesanía renacentista. Pero poco a poco, en diversos textos, Aldana irá condenando la guerra y sus horrores, ya que la acción militar deja su lugar a la actitud contemplativa y a la voluntad de retiro del mundo que se observa en la magnífica 'Carta para Arias Montano'. (García, "Oficio militar..." 599).

Los tercetos encadenados, desde el punto de vista formal, colocan al yo, mediante el deíctico "allá”, en la corte, en contraposición con un yo de la guerra. Esta estructura, además, se aúna a los verbos de movimiento que imponen un dinamismo a las imágenes poéticas. Por ejemplo:

Mientras, cual nuevo sol por la mañana, todo compuesto, andáis ventaneando en haca, sin parar, lucia y galana,

yo voy sobre un jinete acá saltando el andén, el barranco, el foso, el lodo al cercano enemigo amenazando. (vv. 25-30)

Desde el punto de vista del enunciador del discurso hay una plena conciencia de la representación de los espacios bélicos y de su carácter poético. De tal suerte, ya se observa un discurso ideológico e imperialista que va a adquirir cabal sentido en los poemas dirigidos a don Juan de Austria y a Felipe II como los son el LIX y el LX. La contraparte de este discurso está, por ejemplo, en el poema XLV, "Otro aquí no se ve que, frente a frente”, que se analizará en el siguiente apartado, en el que se despliega la composición irónica sobre el 
digno y noble estado de la guerra. En los tercetos, el yo lírico se presenta como severo y seco, y se corresponde a un sujeto que respeta su esencia guerrera, a diferencia del sujeto en las octavas "Sobre el bien de la vida retirada" (poema XXXI). El yo de los tercetos se expresa aliviado y satisfecho de haberse deslindado de la corrupción de la corte al partir a la guerra.

Es evidente un entusiasmo por la vida de soldado, pero es mucho más complejo desde el punto de vista del yo lírico. No sólo es una satisfacción moral o deseo de gloria a manera de un hidalgo que busca la gloria de la corona o de la iglesia. Aunque estén presentes una variedad de elementos que contraponen la vida soldadesca a la vida cortesana, la segunda en detrimento de la primera, el poema construye un discurso que exalta a la guerra, pero no de manera irónica como en poemas posteriores. Estructuralmente, a partir de las antítesis de los tercetos, el sujeto se sitúa dentro de la vida de campaña, para aborrecer la vida ociosa de la corte. Así pues, ejercer las armas resulta honorífico para el hombre. En estos tercetos no existe la liberación del mundo todavía, sino un estado en el que apenas se supera la frivolidad y los placeres mundanos que dejan en el cortesano "manchada el alma más que piel de armiño" (v. 15). De manera análoga, se hace referencia al "honroso sudor" del soldado que enuncia: "yo de honroso sudor cubro mi cara / y de sangre enemiga el brazo tiño / cuando con más furor muerte dispara" (vv. 10-13). El yo poético aún no está desengañado de la guerra, pero sí de la corte, por lo que aún discurre en el mundo caótico y destructor de los horrores de la batalla.

Los tercetos en contrapunto corte-campo de batalla nos conducen a aceptar la superioridad moral del soldado. Rivers plantea una diferencia entre la identidad del poeta florentino frente a la identidad del soldado español que participa de la idea imperial. No se puede reducir a un choque entre "renacimiento italiano" y "contrarreformismo español", sino se debe ver como una lógica poética que responde al humanismo y exalta la política imperial. 
Posteriormente se verá una lógica poética de una religiosidad contrarreformista, desde la cual, en cambio, se condenan las armas.

Carlos Ruiz Silva retoma a Rivers cuando se refiere a un sujeto que participa de la idea de Imperio y por tanto, tiene una actitud inicial bélica (72). En otro nivel está un sujeto que parte la de la cultura italiana clasicista hacia una cultura contrarreformista. No se trata de observar las coyunturas de su vida sino de la compleja construcción del discurso poético en términos ideológicos e históricos, ahora en la Carta para Arias Montano frente a lo carnal y violento:

Oficio militar profeso y hago, baja condenación de mi ventura que al alma dos infiernos da por pago.

Los huesos y la sangre que natura me dio para vivir, no poca parte dellos y della he dado a la locura,

mientras el pecho al desenvuelto Marte

tan libre di que sin mi daño puede, hablando la verdad, ser muda el arte.

Y el rico galardón que se concede A mi (llámola así) ciega porfía Es que por ciego y porfiado quede. (vv. 13-24)

Esta guerra no sólo atenta contra la materialidad corporal, sino contra la inercia del alma del sujeto para regresar a Dios. El espacio de la guerra, entonces, rompe con el equilibrio y la continuidad de las criaturas que emanan del espacio de Dios. La actividad bélica es, por tanto, una desviación del equilibrio en la Tierra. El espacio que se proyecta en estos tercetos conduce necesariamente al yo poético a la soledad y al desvalimiento. 
El oficio militar en los "Pocos tercetos escritos a un amigo", si bien se reproduce como algo más digno que el espacio de la corte, se convierte en un estado que aleja del camino al sujeto. En los tercetos se percibe el orgullo de quien sirve a Marte (en el estado bélico), y que legitima el paso del yo por ese espacio. Un sujeto poético que habla primero desde el "poeta soldado imperial" se disuelve en un sujeto neoplatónico cristiano que condena los excesos de la guerra en la vida temporal.

Antes de proseguir en el análisis de los tercetos conviene atender la importancia de su estructura epistolar. Rosa Navarro Durán descarta que tengan esta marca genérica, pues ni siquiera tienen el apóstrofe inicial (211). Además las partículas deícticas "allá” y "acá” buscan configurar una unidad entre las imágenes que se desarrollan en el poema. Son referencias al mundo real, a los estrépitos bélicos. Esto supone un desplazamiento de las representaciones metafísicas: más que el neoplatonismo y el pensamiento filosófico queda patente un realismo y sensualismo, un tránsito por la vida cortesana que en la instancia de la escritura es desplazado y opone su situación a la del destinatario ficcional. La soledad a la que se enfrenta ahora el yo es consecuencia del abandono de la tierra toscana.

Un aspecto fundamental de los "Pocos tercetos..." es la contraposición de dos instancias públicas: el espacio de la guerra y de la corte, a partir de una ideología. Al respecto Miguel Ángel García expone lo siguiente:

El funcionamiento del Estado absolutista provoca la aparición de dos "aparatos", la burocracia y el ejército, en los que se materializa la nueva ideología burguesa. En concreto el ejército en sentido moderno [...] supone en el nivel ideológico la materialización de la temática de "lo nacional" y del heroísmo militar o la práctica de la epopeya [...]. Por lo que se refiere a la burocracia, permite la consolidación de una nueva figura social, el "escritor", que en el feudalismo no existe propiamente y que, como el soldado, trata de mostrar el mérito exigido para el paso al lugar público [...] tanto la burocracia como el ejército suponen, pues, la materialización más estricta de la esfera de lo público. (606) 
Los tercetos muestran, por tanto, la figura dicotómica de un soldado y caballero, pero en tanto alma privilegiada que inscribe sus hazañas en el espacio público abierto. Más aún, la dialéctica de espacio privado y público se abre por la ideología en el surgimiento de esta nueva clase. Es una progresión que ya se observa en Herrera, y que va de las armas a las letras y del amor a la guerra; es decir, van del espacio privado al espacio público. El tema de lo nacional y lo militar se desarrolla en el espacio de lo público, en detrimento de lo privado del amor, pero para regresar a lo privado de la contemplación y la búsqueda de trascender no en el cuerpo del "otro", sino en el espacio esférico del que emana la sustancia de la naturaleza y que da forma y sustancia al sujeto lírico.

Por otro lado, regresando al espacio bélico, es fundamental considerar que es una apertura a la movilidad y al desplazamiento del sujeto. Lara Garrido considera que "la experiencia quedó reflejada [en los tercetos], donde el yo del guerrero se contempla saltando con su caballo el andén, el barranco, el foso, el lodo y reconociendo el sitio y la trinchera sin temor a la muerte tan cercana" (298). Ese espacio se vuelve sustancia de las imágenes poéticas y desencadena todo el universo de reflexiones en torno a este oficio que se sustentarán en toda la trayectoria poética.

Mientras estáis allá con tierno celo, de oro, de seda y púrpura cubriendo el de vuestra alma vil terrestre velo,

sayo de hierro acá yo estoy vistiendo, cota de acero, arnés, yelmo luciente, que un claro espejo al sol voy pareciendo.

Mientras andáis allá lascivamente, con flores de azahar, con agua clara, los pulsos refrescando, ojos y frente, 
yo de honroso sudor cubro mi cara, y de sangre enemiga el brazo tiño cuando con más furor muerte dispara.

Mientas que a cada cual, con su desiño, urdiendo andáis allá mil trampantojos, mancha el alma más que el piel de armiño,

yo voy acá y allá, puestos los ojos

en muerte dar al que tener se gloria del ibero valor ricos despojos. (vv. 1-18)

Primeramente hay una oposición entre el "allá" frente al "aquí" desde donde habla el yo de la enunciación. Además, "el vil terrestre velo" es lo que recubre al cuerpo y lo escinde del alma. Pero ese velo, de oro, de púrpura y de seda, o ese sayo de hierro son lo mismo. Más adelante la caracterización que el sujeto hace de sí mismo y su resplandor: "sayo de hierro acá yo estoy vistiendo, / cota de acero, arnés, yelmo luciente, / que un claro espejo al sol voy pareciendo", se contrapone a la hermosura externa de los hombres cortesanos. Es un sujeto que ha cambiado por la guerra, que se desdobla del amor en la armas. Hay aún más una distancia entre lo divino y lo sensual y aparente. Como se mencionó, es mediante la fórmula de espacialidad acá y allá que se organiza estructuralmente este poema y que jerarquiza moralmente el tránsito del sujeto enunciador por el espacio del amor cortés, estado inferior y mundano, al espacio honroso y viril de la batalla, y posteriormente en la poética de Aldana, conduce al sujeto hacia el amor divino que trasciende en $\operatorname{Dios}^{12}$. Aquí se regresa nuevamente

\footnotetext{
${ }^{12}$ Esta instancia se desarrollará en el último capítulo.
} 
a la concepción del alma como partícipe del espacio divino y hay un distanciamiento del amor humano.

La contraposición espacial de la corte y el campo de batalla se desdobla en la contraposición moral de la frivolidad de la corte y el sacrificio corporal. Por lo demás, la temática pública de la guerra se sacraliza, pues la defensa de lo nacional coincide con la defensa del catolicismo. Lo que interesa es que la arquitectura del texto surge a partir de esta dialéctica de los espacios privados y públicos, y el sujeto poético se articula en estos tercetos desde el espacio de lo público (contraponiendo guerra y corte) en detrimento del espacio íntimo del amor.

Lara Garrido recuerda que la crítica ha considerado los "Pocos tercetos..." como un poema fundamental para comprender la evolución poética de la obra de Aldana, especialmente la transición de Florencia a Flandes, pues los textos poéticos de esta época de la vida de Aldana advierten un cambio de tema y enfoque en los poemas que va del interés por el asunto amoroso y mitológico a la exaltación del mérito individual del sujeto que combate (289). La actitud del yo lírico dista mucho de la expresada en los sonetos, pues ahora subyace una experiencia real del combate, a través de descripciones plásticas esta actividad. Posteriormente se observará cómo, desde la vivencia del yo lírico que se desengaña, se pretende repudiar la guerra como actividad que aleja al sujeto del bien.

\subsection{El desengaño de la guerra}

El yo lírico se autofigura de una manera muy particular en los poemas cuyo tema es la guerra. Se ha visto en los poemas de temática amorosa cómo en el primer desplazamiento del espacio de la corte hacia el espacio de la guerra, el yo ya se presenta en crisis ante el devenir de la vida mundana; no obstante, el sentimiento de desengaño asalta ya de manera 
insoslayable a este sujeto, específicamente en la actividad bélica. El poema XLV, "Otro aquí no se ve...", es un soneto que se desarrolla únicamente en el espacio bélico.

Otro aquí no se ve que, frente a frente, animoso escuadrón moverse guerra, sangriento humor teñir la verde tierra, y tras honroso fin correr la gente.

Este es el dulce son que acá se siente: «España, Santiago, cierra, cierra!» Y por suave olor, que el aire atierra, humo de azufre dar con llama ardiente.

El gusto envuelto va tras corrompida agua y el tacto sólo apalpa y halla duro trofeo de acero ensangrentado,

hueso en astilla, en él carne molida, despedazado arnés, rasgada malla. ¡Oh, sólo de hombres digno y noble estado!

El primer cuarteto es una descripción sensorial de la guerra. La descripción del escuadrón que se mueve a la guerra en el segundo verso, y el honroso fin tras el cual corre la gente del cuarto verso parecen exaltar la actividad bélica, mientras que el tercer verso “sangriento humor teñir la verde tierra" introduce una ironía respecto a los demás versos. El espacio de la verde tierra, espacio propiamente de la naturaleza, alejado del espacio urbano, se tiñe de la sangre de los hombres. En el segundo cuarteto se introduce un son que evoca el espacio geográfico de España y de Santiago que posteriormente se describe a partir de los sentidos del sujeto enunciador: "el suave olor que el aire aterra" y el humo de azufre. En ningún momento el yo transita por ese espacio, pero describe objetivamente los espacios 
sensoriales y los objetos que remiten a los cuerpos descarnados que atraviesan los espacios bélicos. En el primer terceto se nos describe una corrompida agua, mientras que el tacto palpa el trofeo del acero ensangrentado. El último terceto continúa con la invocación de partes del cuerpo en una completa desmembración, como el hueso en astilla, la carne molida detrás del despedazado arnés, de la rasgada malla, y termina con un irónico verso yámbico. Todo el soneto pinta una serie de horrores que son atravesados por el sujeto lírico a través de los cinco sentidos que van registrando en una gradación descendente (vista, oído, olfato, gusto y tacto), para terminar diciéndonos que es esa crueldad terrenal la que el mundo glorifica.

Lara Garrido explica las diversas interpretaciones críticas que giran alrededor de este poema (344-345). A. Rodríguez Moñino, por ejemplo, interpreta que para el poeta "no hay vida más digna (aparte de la religiosa) que la de su profesión” (19-20). Para L. Felipe Vivanco: "Después de describirnos la guerra en todos sus horrores correspondientes a los cinco sentidos corporales [...] y cuando esperábamos su más rotunda reprobación humana, hace su elogio en un solo verso final, verdaderamente sobrio y sorprendente". Para Vossler, al contrario, se vislumbra una actitud humorística y sarcástica. Para Rivers es el soneto es una paradoja pues “en la guerra, la vida es más vida y la muerte más muerte; es a la vez vil y gloriosa. Dicho de otro modo, este soneto no es una afirmación ni una negación” (159160).

De cualquier manera, el sujeto se autofigura en términos de mostrarse en movimiento durante la batalla. En la medida en que el yo presenta la acción bélica, la revela en todo su horror y captura el movimiento y la plasticidad de una batalla. De tal manera, sí puede considerarse irónica la figuración del yo respecto a esta crudeza pues las sensaciones con las que este sujeto discurre en el espacio de la guerra se traducen en un desengaño.

Asimismo, para Rivers, el poema expresa: 
una angustia espiritual provocada por la contemplación de los horrores de la guerra [...] su poderoso efecto físicoespiritual se consigue por medio de una composición de lugar, o sea un 'traer de los sentidos' [...] Así, uno por uno se aplican los cinco sentidos a la escena sobre la que se medita (ver, oír, oler, gustar y tocar, siguiendo el orden descendente que se establece desde los postulados de Platón y Aristóteles), de manera que el soneto va en un sentido descendente hasta llegar a los ínfimos horrores del tacto. (603-604)

El sujeto que en este caso se autofigura como un soldado, se ve en ese "animoso escuadrón”, escucha el "dulce son” de la batalla, huele el "suave olor" del "humo de azufre”, debe beber de "corrompida agua" y, por último, experimenta con el tacto los elementos más horribles de la situación: el "acero ensangrentado", el "hueso en astilla", la "carne molida". Para Montaner, son imágenes que provienen de la épica y que tienen cargas positivas. Se presentan héroes cabalgando por el campo de batalla lleno de cadáveres, escena de una gran fuerza dramática, de manera que la imagen se constituye en un motivo épico. No obstante, en Aldana la imagen al presentarse desde la posición del sujeto lírico, se convierte en una ironía y la escena tiene un carácter negativo por la falta de correspondencia entre el ideal guerrero y el horror real en el presente de la enunciación (Montaner cit. en Sánchez 23).

La percepción sensorial que se enuncia mediante esta progresión es la vivencia del sujeto respecto a la batalla, de manera que se da cuenta de la actitud del yo lírico. Si bien se encuentran valoraciones positivas, el hecho de enunciar la vivencia sensorial de este poetasoldado que aparece como voz y exceso en el lenguaje, conlleva una valoración irónica de la instancia de la batalla, como los son el "dulce son" referido al grito de guerra o "suave olor" al "humo de azufre".

Más aún, no puede haber valoraciones positivas al terminar el segundo cuarteto con la "llama ardiente", que es una imagen negativa. La descripción de las sensaciones de la batalla se hace más descarnada conforme se desciende por los diferentes sentidos; así, cada 
vez más, aunque ya desde el principio, la ironía se apoya sobre todo en el contraste entre la pretendida alabanza de la vida militar y una descripción muy plástica que resalta los aspectos más horribles de la vida militar: la batalla, la sangre, las profundas heridas y la muerte. Lo que impulsa a la figura del soldado a combatir en el escenario dispuesto por la imagen de la sangre empapando la tierra "sangriento humor teñir la verde tierra" es el "honroso fin". Para Rivers, incluso, representa el choque entre la vida y la muerte (603).

El último terceto nos presenta los horrores que experimenta el tacto, por lo que se logra una imagen plástica que impacta no sólo al sujeto enunciador, sino al destinatario de la lírica. Es una cruda y material descripción: huesos astillados, carne molida y armaduras despedazadas en un espacio lleno de sangre. Por lo tanto el verso final "Oh, sólo de hombres digno y noble estado" termina siendo una lamentación tras esa ironía en que se condena no sólo la batalla sino el hecho de enaltecer la vida soldadesca, cuya dignidad y nobleza son insostenibles en la batalla real.

Es sumamente importante para el proceso de autofiguración el movimiento en este soneto porque desde el primer cuarteto se construye la imagen de un ejército que se mueve hacia la batalla en un estado animoso. De manera simultánea la sangre tiñe la tierra. Asimismo se enfatiza con el verbo correr del cuarto verso ese movimiento hacia el "honroso fin"; no obstante, las dimensiones temporales del soneto se despliegan tras el recorrido sensorial, que en última instancia y lo que más interesa en este análisis, es que dispone las impresiones subjetivas de un sujeto herido. Lara Garrido anota que el recorrido de los sentidos es precisamente lo que dota al poema de dimensiones temporales (85).

El lector al que se le presenta esta imagen dinámica atiende al frenesí de la batalla. Por lo demás, el movimiento con el que se despliegan los textos poéticos del corpus es un aspecto fundamental para caracterizar la vida como una transición en la que discurre ese 
sujeto que acumula sus experiencias vitales y traza el camino que se pretende racionalizar en esta investigación

El rechazo de la acción bélica motiva una determinada interpretación por parte de algunos críticos, que consideran (apoyándose muchas veces en datos biográficos) que Aldana refleja aquí su desagrado creciente por las armas, hasta el punto de afirmar, como Ruiz Silva, que, "condenado a una vida militar que en el fondo le repugnaba, el poeta se sirve de una sangrienta ironía entre la postura oficial, es decir, la nobleza de la milicia, y la realidad que tantas veces sintió en su propio cuerpo y en su propio espíritu” (121).

En contrapunto, Rivers considera que

[...] aunque Aldana estuviera personalmente desengañado con la mundanalidad de sus propias ambiciones soldadescas, seguía propugnando, bien que con cierto pesimismo, el cumplimiento vigoroso del destino imperial de la España militante como única defensora de la Fe. (547)

Por último, la subjetivación de la experiencia bélica supone que el yo lírico ha dejado de creer en ese ideal de adquirir la honra que es en realidad una práctica violenta; es decir, el yo hace posible el cuestionamiento de dichos valores de dignidad y nobleza que se diluyen ante una realidad vital de sufrimiento y muerte, que se funda precisamente en la figuración del sujeto poético dentro de las imágenes poéticas.

\subsection{El repudio de la actividad bélica}

Ya se ha comentado sobre la importancia de los "Pocos tercetos..." como un poema fundamental para comprender la evolución poética de la obra de Aldana, y su paso entre Florencia y Flandes. Rivers considera ciertos datos autobiográficos para afirmar que en Flandes nace el ideal guerrero que le pertenecía a la familia de Aldana, aunado al contacto 
con el Duque de Alba y a las campañas españolas contra los infieles (505). Hay que advertir la crisis con la llegada a Flandes que transforma la visión del poeta. En la "Respuesta a Cosme de Aldana, su hermano, desde Flandes" (XXXV):

Y bien me acuerdo yo que allá en el monte

y allá en el valle, a la ribera de Arno

( $;$ ay monte, ay valle, ay Arno, ay mi ribera, cómo vivo yo aquí lloroso y triste!)

[...]

En fin, en fin, la tenebrosa noche

salió de aquel dorado y claro día,

y como allá dejé la mejor parte

de mí, de amor, de tiempo y de fortuna,

allá quedó también, con bienes tantos,

la musa. ¡Oh, musa mía!, pues calla, queda.

(vv- 81-96)

La soledad del yo se advierte en el contraste entre la luz de Florencia y Bruselas, aunado al al desplazamiento de un mundo joven a un mundo real y bélico. A saber, los biografemas de la juventud que auxilian la edición y disposición temática de toda la obra conocida del poeta, se caracterizan por una vida cortesana y relajada, que contrasta fuertemente con la acción bélica.

Sánchez Mairal señala que:

Además de la nostalgia de la vida florentina, hemos advertido ya el cambio del horacianismo que repudiaba con horror la guerra de su juventud, como decía Rivers ${ }^{13}$, a la exaltación guerrera, que desembocará, como también hemos visto, en otra forma de rechazo, planteada desde un nuevo punto de vista. (29)

\footnotetext{
${ }^{13}$ Para Elías Rivers varias de estas muestras poéticas pertenecen al horacianismo, pues muchas de las epístolas poéticas de Aldana se basan en la actitud de intimidad y amistad sincera (616).
} 
Este rechazo se evidencia en el poema XXXI "Sobre el bien de la vida retirada"

No de Marte feroz, bravo, impaciente, veré la confusión, la muerte y pena, ni veré que mi espada se ensangriente de propia sangre o de la sangre ajena, ni en medio del verano más ardiente, cuando Aquilón su helado soplo enfrena, sin aliento, sin vida y sin sentido, verme he de sangre y de sudor teñido. (vv. 249-256)

En estos versos existe un repudio por parte del yo lírico que asume la enunciación detrás del verbo "veré". El sujeto verá su espada ensangrentada así como la confusión, la muerte y la pena, y finalmente el enunciador asume la condición del soldado: "verme he de sangre y de sudor teñido”. El contrapunto se expresa desde la caracterización de los sujetos que transitan por el espacio: "un Marte en armas y en la corte un Febo" (v. 275).

El sujeto lírico no se autofigura como en el soneto XLV, en el que rechaza a la guerra tras su experiencia, articulada desde lo sensorial, sino de una vivencia mucho más intelectual y una plena conciencia literaria del quien enuncia. Sanchez Mairal enumera los motivos virgilianos y bíblicos como lo son: "1) la contraposición de los estados de codicia (vv. 1200); 2) negativa a ser perturbado en el futuro por los peligros de la mundanidad (vv. 201296); 3) alabanza del pastor como modelo de vida retirada (vv.297)” (16).

Carlos Ruiz Silva también resalta coincidencias con Fray Luis de León, con el que muy probablemente intercambió versos a través de su común amigo Arias Montano (62). La autofiguración es aquí muy diferente al soneto XLV, pues su actitud hacia la guerra

\footnotetext{
${ }^{14}$ Lara Garrido la sitúa en el periodo florentino (es decir, en la juventud de Aldana) a partir de un poema de Cosme (236).
} 
rechaza más bien una participación en ella, en lugar de transitar sensorialmente por los espacios de la misma. Aunque asume la enunciación, se ha dicho que el verbo está en conjugado en futuro, y la alusión a la guerra se convierte en un concepto mucho más general y abstracto. También las imágenes que se proyectan más bien son de corte épico y como tal no ocurre un desengaño del sujeto que enuncia sino un rechazo de lo que implica la actividad bélica, y que tiene que ver con una filiación ideológica. Por tanto no se pretende una oposición entre dos espacios como se ha visto en los anteriores apartados, sino un rechazo ideológico a lo que implica la vida mundana, el ansia de gloria, lo material, el deseo carnal y que está comprendido por la guerra. Por ejemplo: "Viva el tirano allá, si nombrar vida / se puede un duro y tímido recelo” (vv. 65-66); "Cuelga del mal tejido y débil hilo / que extiende en larga tela la esperanza, / tú, cortesano..." (vv. 97-99); “Breve y triste placer, largo tormento, / [...] / tienes, amante, allá por fundamento" (vv. 129-133); etc.

Asimismo, las siguientes dos octavas muestran el rechazo al avaro y adulador, que tipifican aquello de lo que el sujeto poético quiere distanciarse:

De ilícita ganancia el arca llena nunca veré, ni que en mi daño cese, ni aquel mentir jurando, sin más pena, como si en el mentir la verdad fuese. ¿Cuál alma endurecida o más ajena de verdad o bondad hay que no diese, a trueque del profano y del perjuro, su bien o mal a estado más seguro?

No sentiré del patrimonio incierto la cierta perdición horrible y fiera, no al sol, al agua, al aire descubierto iré rogando a quien mandar debiera; aquel vivo morir tan claro y cierto 
y el adular con voz tan lisonjera, aquel buscar favor, medio y testigo, mis pleitos entregando a mi enemigo. (vv. 233-248)

\subsection{La ironía del soldado}

La actitud de rechazo a la guerra y a la vida mundana desde el punto de vista intelectual ocurre de manera diversa en la obra de Aldana, y corresponde a un proceso específico en el que el sujeto poético construye une perspectiva que puede interpretarse a la luz de ciertos biografemas. Por tanto, los "Pocos tercetos..." anteriormente mencionados, al estar escritos en Flandes, ya suponen una actitud y un juicio volitivo distinto del sujeto enunciante. Como se ha comentado igualmente, es la razón por la que constituyen un punto de inflexión en el carácter de su producción poética. Si bien en estos tercetos se rechaza la vida mundana y específicamente la vida cortesana, se exalta el estado noble de las armas. En un segundo momento, como en el poema XLV, se presenta el desencanto del ideal bélico a través de una experiencia empírica del yo lírico.

Esta experiencia no tiene que ver con el autor ni con ningún asentamiento extraliterario, sino con la vivencia que se produce desde la figura que se ha construido por medio del yo. Esa vivencia que se articula en el poema LIV, y que la crítica también ha interpretado a la luz de la derrota del ejército español en Alkmaar y en la que Aldana fue herido, sólo interesa en la medida en que el sujeto enuncia desde una experiencia destructora que tiene como consecuencia el desengaño de ese primer yo que se ha desdoblado y acumulado experiencia y conocimiento.

En este poema la guerra no se muestra como un estado ideal, a la luz del conocimiento, de la tradición literaria o histórica, ni como una vivencia del horror desde el 
mundo sensorial. Se presenta como una experiencia destructora desde un sujeto que muestra la conexión entre su pie herido y la cabeza.

Este poema corresponde a un diálogo o debate que pude relacionarse con esta tradición medieval (Lara 385). No únicamente tiene un tono jocoso, sino que todo el tiempo el sujeto se reconecta con la experiencia de horror y el sufrimiento desde su propio cuerpo, a semejanza del poema XLV, aunque en éste ocurría de manera más impersonal.

Hay una conexión entre el pie herido y la cabeza, mediante la cual se comprende la naturaleza de la guerra. El pie asume la queja a manera de sinécdoque y describe con una imagen plástica el dolor físico. Vossler (182) y Rivers (634) coinciden en el carácter dialógico del poema y la originalidad de los personajes que dialoga. Miguel Ángel García (545) considera que se ve el conceptismo ingenioso y humorístico. Lo paradójico de este poema es la construcción de la herida y el reflejo del sufrimiento a partir de un carácter jocoso e irónico como considera Ruiz Silva (207). Lo que interesa de la discusión entre el pie herido y la cabeza sobre quién es el culpable, es el desdoblamiento del sujeto poético en una forma discursiva dialógica.

PIE Pues, si manda la cabeza, sin que el pie diga de no, por sólo que obedeció, cuando ella cae o tropieza dicen que el pie tropezó, $[\ldots]$

Pues, ¡cómo! ¿El dolor es mío, y tú, cabeza, te quejas?

Pocas vi, cabezas, no ser ansí, que, por mostrar que lo son, do tienen menos razón 
más muestran hacer de sí. (vv. 71-90)

No es únicamente un debate, sino que en todo momento se retorna a la vivencia del sujeto y la manera en que pasa por la razón, y la razón no del sujeto poético sino de todos aquellos que ordenan en la guerra:

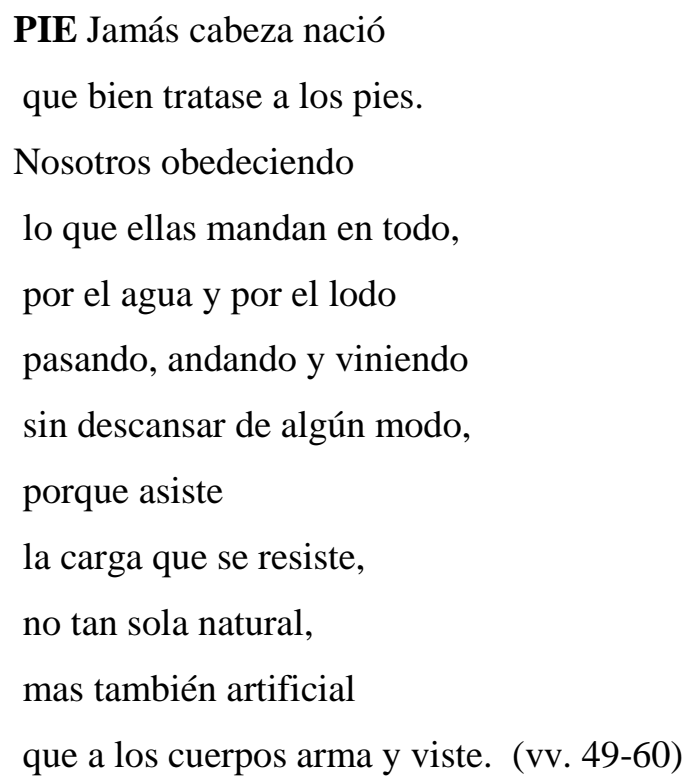

La experiencia militar del soldado se ve representada por la del pie, y el movimiento por el que transcurre éste, "por el agua y por el lodo / pasando, andando y viniendo", se relaciona con la vivencia de un yo en movimiento en los "Pocos tercetos" o en el soneto XLV. Este discurrir del sujeto se analizará en el último capítulo, en el que el movimiento es el eje central de la autofiguración. En esta instancia, el transcurso de la guerra y los espacios por el que el yo lírico se mueve fatigoso, se conectan con la experiencia y el absurdo de la actividad bélica por la destrucción corporal que supone.

\section{CABEZA ¡Malcrïado!}

¿Desa manera has hablado?

PIE ¡Por Dios, que es gentil crïar haber sin huesos de estar tras haberlos bien crïado! (vv. 81-90) 
La queja enfatiza los horrores físicos que experimenta el sujeto, desde el sufrimiento fisiológico a causa de la experiencia militar. A diferencia del soneto XLV que también resulta irónico, en este poema no hay un desengaño respecto a un ideal, sino una crítica desde la vulnerabilidad del sujeto que se sirve de estrategia del diálogo para contrapuntear al soldado que obedece frente al poder que lo dirige. Lo que en definitiva pasa en este poema es que el sujeto lírico se autofigura como un soldado concreto, y que poco a poco, a partir del ejercicio de las armas, se perfila para entrar en una crisis vital, que desemboca en la actitud espiritual para enfrentar la vida terrenal, que se verá en el siguiente capítulo.

\subsection{La trascendencia del Imperio Español}

Algunas de las implicaciones del análisis conducen irremediablemente a una interpretación ideológica; a saber, la tensión entre un ideal guerrero históricamente determinado, una cultura florentina frente a una realidad convulsa del imperio español, bastión de la contrarreforma, y específicamente como una realidad empírica que atraviesa al sujeto de la enunciación. Esto último es la condición de posibilidad de un yo que se desdobla en tiempo y espacio y traza, desde el enfrentamiento con la realidad, su devenir. El rechazo de la guerra, por tanto, no se trabaja desde una abstracción lírica, sino por un yo que asume la palabra desde el cuerpo.

Dos composiciones que exaltan la idea imperial y el destino de España son las "Octavas al serenísimo señor don Juan de Austria" (LIX) y las" Octavas dirigidas al rey don Felipe, nuestro señor" (LX). En las octavas dirigidas a Felipe II la crítica ha visto una actitud contradictoria del sujeto textual: cómo es que éste, que perfilaba la crisis de la corte a la guerra y a la vida contemplativa, se desvía para ofrecer un rostro tan diferente (Ruiz 
187). Si bien se ha concluido un carácter contradictorio e incluso una tendencia más oficial de esta poesía después de que la crítica ha afiliado ciertos biografemas con la vida política de Aldana, habría que recordar que armas y letras son ámbitos complementarios. A diferencia de Ruiz Silva, Rivers dice que "aunque Aldana estuviera personalmente desengañado de su propia experiencia guerrera, seguía propugnando, bien que con cierto pesimismo, el cumplimiento vigoroso del destino imperial de la España militante como única defensora de la Fe" (547). Por ello, este sujeto puede repudiar la guerra desde su experiencia vital, pero racionalizar la necesidad de la misma para los fines imperiales, independientemente del sujeto.

Carlos Ruiz Silva advierte, respecto a estos poemas, que la única intención del poeta es "trazar [...] la serie de peligros político-militares que acechan a España en esos años". Retoma que Luis Rosales y Luis Vivanco en Poesía heroica del Imperio y Ricardo del Arco y Garay en La idea de Imperio en la política y en la literatura española defienden la idea de que Aldana es mejor capitán que poeta, y que en sus octavas únicamente traza un programa imperial político (ambas publicaciones, de la posguerra civil española buscan un puente de continuidad ideológica entre el s. XVI y los primeros años del franquismo) (67).

No obstante, hay lecturas que recientemente han intentado revalorar las "Octavas a Felipe II" y restituir su valor poético. "Visión, alegoría y discurso en las Octavas a Felipe II de Francisco de Aldana" y "Las Octavas a Felipe II de Francisco de Aldana: de la construcción retórica al discurso poético como mitologema”, ambos de José Lara Garrido, y La poesía de Francisco de Aldana (1537-1578) de Dolores González Martínez, son estudios que trabajan sobre la forma y función de las Octavas desde diferentes perspectivas.

Este largo poema y texto político, escrito hacia 1577, se compone de 110 octavas que contienen 880 versos. Comienza con una visión alegórica: dos mujeres se acercan, una vieja 
que viste de militar, y otra joven que viste de blanco. Ambas llegan hasta el rey Felipe. La primera se arrodilla, mientras que la segunda permanece parada y simboliza la iglesia. A lo largo del poema se personifica la guerra y se manifiesta a conciencia que africanos, asiáticos, ingleses y flamencos, herejes e infieles, ven crecer su poderío mientras que España decae.

En las “Octavas a Felipe II”, Aldana traza la volición de un utópico proyecto político y religioso, mediante el cual el espacio español se regeneraría, unificaría y alcanzaría su dominio universal; a saber, España como bastión del catolicismo que debe expandirse territorialmente. Por ello, en tanto estas octavas son un acertado discurso retórico, podemos considerar los variados momentos en que el enunciador lírico alude a la recepción y mueve al receptor a una identificación emotiva, aunque se intercalen momentos que sostienen una estrategia imperial.

Se puede observar que el exordium no se encuentra al inicio del discurso, sino que se integra en la quinta estrofa, una vez que ya se han presentado las dos alegóricas mujeres que funcionarán como parte de la querella.

Rey soberano - la mujer armada

Dice, son de pecho alto y robusto-

A quien se debe sujeción amada

Del cita helado al etíope adusto,

En quien estriba Europa bautizada

Como en su defensor, cristiano Augusto,

Pido atención, tan dulce como larga,

A mi razón, tan corta cuan amarga. (vv. 33-40)

Esta disposición es fundamental porque cumple con el objetivo de construir al receptor dentro de la querella: son los mismos personajes alegóricos quienes apelan a este Rey ficticio. Además, son estos personajes en los que se codifica el espacio simbólico. Las 
octavas, pues, se organizan articulando discurso y texto lírico y hay una manipulación narrativa del yo, que se sitúa fuera de la escena, en función de la efectividad: la construcción de la persona que funciona como receptor del discurso visionario del sujeto poético y que coincide con el destinatario histórico del poema (el Rey Felipe II).

Aquí dio fin la vieja a su querella

Y puesta en pie, serena y reverente,

Se despidió, tomando a la doncella

Del brazo, con humilde y baja frente;

Ella también, cual matutina estrella,

Su rostro vuelto al rey, claro y ardiente,

Hablóle con los ojos de manera

Que al más helado risco enterneciera. (vv. 873-880)

Primeramente, la estructura retórica del poema obedece a un discurso deliberativo. Desde el título se perfila que el receptor va a ser un árbitro que puede tomar una decisión política, mientras que el objeto discursivo versa sobre lo que puede o no suceder. Por lo demás se subraya la autoridad militar del sujeto enunciador, así como la autoridad del receptor. Este discurso se desdobla en una querella, de forma dramática como en el poema LIV, entre dos figuras alegóricas que están teniendo una comunicación que aún no llega a materializarse, ya que es una visión del sujeto poético.

La adecuación de este discurso se posibilita mediante el predominio de formas verbales de visualidad que construyen las imágenes. La evidencia del sujeto de la enunciación que establece la proximidad de la visión hace corresponder la certeza del discurso pronunciado por la figura alegórica de la persona ficticia. En las octavas, la única alternancia de tiempos verbales del presente de la visión y el pasado del final ("aquí dio fin”) sirve como marco para la autonomía de esta voz y de su experiencia respecto al poema. Dentro del mismo 
discurso se codifica un emisor y un receptor que pretenden coincidir con el emisor y receptor históricos, pero son construcciones ficcionales.

Lo visual apela al interlocutor para que contemple, y ahí se sustenta la implícita participación de ambos. La figura alegórica enuncia en formas que combinan los tiempos verbales: "que no merezco / ver" (vv. 114-115), "que ver se me figura” (v. 261), "que yo veo” (v. 285), “siempre vi” (v. 445), “con atento / ojo la contemplé” (vv. 471-472). La visión se construye en relación al espacio real, porque es éste en el que se debe incidir (y el interlocutor real se debe conducir al movere). El espacio de la guerra, simbolizado en la figura, apela a al rey para presentar la situación de desamparo, y se hace presente a la mirada. Es una petición hacia el rey y hacia la iglesia. Por lo tanto, el sujeto lírico se sitúa sí dentro del poema, pero recurre a estrategias retóricas para no implicarse en el discurso.

Si bien es mediante la estructura de una visión que se organiza el poema, las imágenes corresponden a la semejanza de espacios, cuerpos y naturalezas. Sus figuras responden a la tipología de "dos mujeres de forma, hábito y ser bien diferentes": la vieja y la doncella. En primera instancia son un contraste entre juventud y vejez, que dramatizado por la anciana y la doncella alcanza un grado semántico que se extiende al espacio histórico. La mujer que se presenta en primer lugar:

Viste de militar, lucido arreo, con airoso ademán, grave y valiente, cierra el puño un asta, do parece que el hierro más que estrella resplandece. (vv. 5-8)

Por lo demás, como discurso político tiene el objetivo de recomendar una acción que ha de influir sobre el curso de los acontecimientos históricos y debe ejercerse la persuasión sobre quien va a ejecutar la acción del establecimiento de la universalidad cristiana con la 
hegemonía de España. Para el cumplimento de esta acción es necesario que el discurso obligue a quien ha de llevarla a cabo: "tan aceto lugar contigo cobre / que lo que digo yo tu valor obre" (vv. 35-36); o bien, "Sólo que metas pido (y esto basta) / en obra, ¡oh rey!, en obra lo que vales" (vv. 800-801), y en los versos:

Y no pienses, ¡oh rey!, que es éste sueño

$\mathrm{O}$ fantástica imagen aparente;

Es conceto común que el más pequeño

Y el más granado pecho dice y siente,

Y puédese inferir ser Dios el dueño

De voz que corre así públicamente,

Pues de necesidad, quien bien lo mide,

Causa común común efeto pide. (vv. 121-128)

Al interior de la argumentación se escenifica la reacción del destinatario:

Rey, las nevadas sierras no parieron

Tu cuerpo en la infantil nueva terneza

$[\ldots]$

Los escabrosos riscos no crecieron

En tu pecho real con su dureza,

Para que no te mueva esta llorosa,

Que en tu presencia está, de Cristo esposa. (705-712)

En las octavas coexiste la fabulación poética y ficcional, ajena a la propuesta político militar; no obstante al organizar esta discursividad mítica y codificar al receptor / enunciador dentro del discurso, lo mueve a tomar una decisión política en el curso del espacio histórico que se escenifica alegóricamente.

En el poema, el yo de la enunciación articula a manera de imágenes y símbolos, más que de conceptos, la figura del rey. Este rey debe incidir en el mundo histórico, en el que se 
pugna entre el Bien y el Mal, y llevar a término la "monarquía universal", que es una metáfora que asigna el alcance geográfico del imperio al término del universo. 


\section{Capítulo 4. La autofiguración del sujeto lírico a partir de la crisis}

\section{espiritual}

\subsection{La condición humana}

La obra de Aldana se construye en torno a ámbitos ideológicos acordes con la corriente humanística y filosófica de su tiempo; a saber, la principal preocupación gira en torno al hombre y a su destino, que muchas veces se desprende como una fuerza desconocida y negativa. Dolores González Martínez refiere que "La poesía de Aldana, en general, es fruto del deseo de resolver su problemática vital valiéndose de la palabra poética, y de ahí que ésta gira en torno a la reflexión sobre Dios y el hombre, sin olvidar, no obstante, el aspecto afectivo y sensitivo en este último" (La poesía de Francisco de Aldana, 27). Las imágenes que se generan en torno a la autofiguración del yo en este eje temático expresan cuestiones relacionadas con la conducta humana, la actividad intelectual y la vida social, como la confrontación clásica entre el hombre sabio, y aquel poseído por innumerables vicios como la codicia, la envidia, la soberbia, la vanagloria, la lujuria. Este comportamiento está íntimamente relacionado con la vida pública, en su manifestación cortesana y política.

Los sonetos LV, LVI, LVII y LXI son los poemas que más claramente representan a un yo poético ya desengañado del mundo. En este apartado se analizarán desde el punto en que permiten una reflexión por la condición humana a partir de la experiencia vital del yo lírico. En todos ellos encontramos a un sujeto abatido de su propia existencia. Una condición fundamental para la autofiguración de este yo desde su reflexión por la condición humana es que el sujeto que enuncia se coloca en una perspectiva de madurez respecto al resto de su vida. Siempre hay una mirada hacia el pasado, caracterizada por el movimiento constante, la 
agitación, el caos y la transitoriedad. La actitud de este yo hacia la experiencia vital tiene siempre un dejo de nostalgia ya que sabe de la fugacidad del mundo: nada es permanente y todo conduce al estado de la muerte.

La primera consecuencia es que el mundo material resulta contingente y vanidoso, así como el cuerpo. El alma, por tanto, permanece en un cuerpo material que le impide alcanzar un estado verdadero y definitivo de Dios, como en el pensamiento platónico. El yo se presenta ante su existencia como una serie de elementos dicotómicos que siempre se encuentran en movimiento: vida-muerte, movimiento-quietud, dolor terrestre-felicidad celestial, etc.

El soneto LV ha sido considerado uno de los poemas más pesimistas de la obra de Aldana. Precisamente el yo se coloca en un momento de angustia y desesperación sin precedente, ante una realidad que le es incluso imposible de expresar.

Mil veces callo que romper deseo

el cielo a gritos, y otras tantas tiento

dar a mi lengua voz y movimiento, que en silencio mortal yacer la veo.

Anda, cual velocísimo correo, por dentro al alma el suelto pensamiento, con alto y de dolor lloroso acento, casi en sombra de muerte un nuevo Orfeo.

No halla la memoria o la esperanza rastro de imagen dulce y deleitable con que la voluntad viva segura.

Cuanto en mí hallo es maldición que alcanza, muerte que tarda, llanto inconsolable, desdén del cielo, error de la ventura. 
El yo lírico sufre una desolación tan intensa que, por mucho que lo intente, le resulta imposible expresarla. Este silencio externo se contrapone a su profunda agitación interna, plasmada a través de la imagen del pensamiento moviéndose por el alma. En Francisco de Aldana, el Divino Capitán, Rivers expone que "el poeta expresa lo frustrado que se siente al no poder manifestar su desesperanza; y esta impotencia, a su vez, le hace más desesperado" (604). Es, pues un yo que se debate en una contradicción angustiosa e insalvable, agravada por la incapacidad de expresar tanto dolor. Ya aquí apreciamos la sensación de movimiento constante que domina todo el soneto, en este caso, referido a la agitación interior: la angustia y la frustración se presentan como proceso repetido una y otra vez a través de la hipérbole "mil veces" y luego "otras tantas", que proporcionan gran intensidad expresiva. Este movimiento continuo es también el de la búsqueda frustrante de algún tipo de felicidad o consuelo en el mundo, que se irá perfilando en los versos siguientes. En el segundo cuarteto, el "suelto pensamiento" se compara con un "velocísimo correo", a su vez comparado con Orfeo en "sombra de muerte", de manera que se plantea la indagación interior como un descenso ad inferos. Esta idea, junto con la del silencio del primer cuarteto confluyen para Lara Garrido, “en la imagen de Orfeo como símil del 'interior hombre’ [...] donde proyectar la situación próxima a la que se llama en la Santa Escritura 'sombra de muerte'” (389). Esta sombra es una metáfora de todas las dificultades que angustian al ser humano.

El pensamiento se describe mediante el símil "velocísimo correo", que se aúna al movimiento y expresa la agitación interior del sujeto; este proceso es, en definitiva, doloroso ya que no tiene consuelo ni mediante la expresión por la palabra, ni la reflexión interior. De tal manera, el primer terceto anuncia una completa desolación ya que en el mundo no hay "rastro de imagen dulce y deleitable" para el alma del yo. En este soneto, la autofiguración de este sujeto se produce con conciencia de su existencia temporal, de manera que la 
proyección hacia el pasado penetra en la memoria del yo lírico. Esta búsqueda en el pasado también permite un desdoblamiento hacia el futuro, en el que sólo encontraría desesperanza. Lo anterior se expresa contundentemente en la enumeración que acumula elementos de crudeza: "maldición que alcanza", "muerte que tarda", "llanto inconsolable", “desdén del cielo", "error de la ventura".

Así como en toda la poética de Aldana, la vida como movimiento se expresa mediante el camino vital de un sujeto poético que tiene una conciencia de su presente, desde donde enuncia, y fundamentalmente de su pasado y en consecuencia, de la desesperanza de su futuro. Este camino de la existencia apunta a una reflexión sobre la condición humana, insalvable, como se comprende en el "desdén del cielo", en el que ni siquiera Dios puede responder a los dolores del hombre. Sánchez Mairal sugiere la influencia del Libro de Job. La actitud del sujeto se asemeja a la de Job:

Desesperado por su sufrimiento, maldice el día en que nació y se pregunta por qué Dios da vida al hombre para que viva en un mundo desdichado y miserable: 3:20 ¿Por qué se da a luz al que sufre, y vida a los de ánimo amargado 3:21 Que esperan la muerte, y ella no llega aunque la buscan más que tesoros; 3:22 Que se alegran sobremanera y se gozan cuando hallan el sepulcro? 3:23 ¿Por qué se da vida al hombre que no sabe por dónde ha de ir, y a quien Dios ha encerrado? (10)

Este soneto es quizá de los más desoladores en la producción poética del autor, pues ni siquiera la liberación del yo atrapado en la existencia puede tener lugar en la "muerte que tarda". La crítica señala la importancia de esa sensación de movimiento interior: la búsqueda angustiosa del alma. Rivers en su estudio Francisco de Aldana, el divino capitán, comenta que "el concepto central es lo suelto del pensamiento: la voluntad no tiene en qué fijarse. En vez de meta segura, no halla más que maldición, muerte, llanto, etcétera” (605). Por lo demás, los verbos que aparecen en los cuartetos como "callar", "romper", "mover" son de 
movimiento y conflicto, específicamente del alma, razón por la cual ocurre al interior del yo que permanece en silencio incapaz de expresar al exterior su dolor, y de manera análoga, lo inerte de la voluntad. Desde este punto de vista, la sensación de movimiento y la tensión que expresa negatividad se construye desde el comienzo con la oposición entre el callar y el querer gritar, el moverse y el paralizarse.

Ahora bien, el soneto LVI también reflexiona sobre la condición humana, pero ahora con una salida más allá de la vida carnal.
¡Ay, que considerar el bajo punto
del estado mortal al alma hiere!, mas de tal peso alienta y la requiere alta contemplación de su trasunto;
pero con esto el gran rector conjunto aquel tributo contrapuesto infiere do, no con celo, tanto el bien se quiere cuanto a la humana parte el mal va junto.

No sé si, al sostener la fatigosa vida, fuera mejor falto juicio, con que el dolor se engaña y no se siente,

o si sentir en todo toda cosa, con tal daño del alma y perjuicio, es más alivio a la pasión doliente.

El yo ya no se autofigura a partir de un debate y sufrimiento interno, sino a partir de una contradicción que atañe al mundo exterior: el alma aspira desde su estado terrenal, a retornar a un mundo espiritual; no obstante esto resulta imposible en la vida ya que el alma se encuentra atrapada en la materia. El yo se plantea si es menester sufrir el alma velada por el 
cuerpo y vivir con la esperanza, inalcanzable en la vida, de aspirar a Dios, o bien ignorar dicho "estado mortal". De cualquier manera la condición humana sigue respondiendo al "bajo punto del estado mortal" y a la "fatigosa vida" de lo terrenal.

En el soneto LV no se mencionaba la causa concreta de la crisis del yo. En éste, por el contrario, es el mundo exterior el que ocasiona el dolor, y por tanto, se convierte en un estado transitorio y temporal que supone una esperanza para el alma de salir, al fin, del cuerpo, no sin producir sufrimiento. Otra cuestión importante sería la contraposición de "tanto el bien se quiere / cuanto a la humana parte el mal va junto", es decir, el bien está unido al mal de la humana parte. Aún no estamos en la producción poética que se resguarda en esta última esperanza y ansía una vida retirada, pero ya existe la reflexión sobre la angustia del hombre y sobre las causas que mueven al alma hacia Dios. Por el momento, en los tercetos se puede estimar lo que mueve al yo a su cuestionamiento y reflexión, que se construye a partir de contrapuntos que expresan la contradicción de la vida terrena.

La autofiguración del sujeto lírico desde la reflexión sobre su condición humana sigue su desarrollo el soneto LVII.

El ímpetu crüel de mi destino, ¡cómo me arroja miserablemente de tierra en tierra, de una en otra gente, cerrando a mi quietud siempre el camino!

$¡ O h$, si tras tanto mal grave y contino, roto su velo mísero y doliente, el alma, con un vuelo diligente, volviese a la región de donde vino!;

iríame por el cielo en compañía del alma de algún caro y dulce amigo, 
con quien hice común acá mi suerte;

¡oh qué montón de cosas le diría, cuáles y cuántas, sin temer castigo de fortuna, de amor, de tiempo y muerte!

Miguel Ángel García, en "Sin que la muerte al ojo estorbo sea”. Nueva lectura..., argumenta que en este soneto ya se perfilan de forma nítida las claves que conducen a la “Carta para Arias Montano": el retiro, la amistad y el amor divino, aunque todavía no se llega a la búsqueda de la contemplación de Dios (561-564). En el poema se observa la continuidad del soneto anterior en cuanto a un proceso de crisis y búsqueda de esperanza que, como es propio al neoplatonismo, sólo ocurre tras la muerte. De manera análoga al soneto LVI, el yo se presenta en el mundo terrenal incapaz de ascender a lo divino; no obstante la mirada de este sujeto ya no versa sobre el mundo terrenal exterior, sino sobre la contemplación de una vida después de la muerte.

Aquí el yo empieza a rechazar "la fatigosa vida", impulsado por el "ímpetu cruel de [su] destino" que nuevamente expresa un movimiento angustioso: se nos presenta intranquilo y en este momento anhela una quietud inalcanzable. Ahora bien, el destino es el motor del movimiento, agente causante de que el sujeto esté siendo arrojado miserablemente "de tierra en tierra, de una en otra gente". El yo experimenta el desasosiego de esta agitada realidad, y lo conducen a desear navegar por el espacio del cielo.

El eje de este soneto es el contrapunto entre movimiento y quietud: el yo transita por la Tierra (que también es la actividad bélica vista en el capítulo anterior) pero ya no existe su voluntad inerte como el soneto LV, sino que el destino es responsable de "arrojarlo" violentamente en contra de su voluntad. Son muy palpables las quejas del yo sobre la fatiga 
humana, consecuencia de que la condición humana obedece a la existencia como una peregrinación en un plano horizontal (de tierra en tierra). El eje que cohesiona este soneto es precisamente la contraposición entre el fatigoso plano horizontal de la existencia caracterizado por "tanto mal grave y contino", frente al plano vertical de ascensión al cielo, "la región de donde [el alma] vino". Esto último se aúna a la metáfora de un velo corporal que el alma debe romper.

A diferencia del soneto LV y LVI, en los tercetos se alcanza a vislumbrar una esperanza para esta alma liberada del movimiento angustioso y caótico de la vida mundana, hacia su contraparte, la quietud celeste, un mejor mundo en donde almas gemelas puedan reencontrarse. No debe pasar desapercibido que la pretensión de un reencuentro también pone en funcionamiento la memoria y proyección hacia el pasado del yo, quien necesariamente recuerda un estado de felicidad y libertad que podría repetirse "en compañía / del alma de algún caro y dulce amigo" tras haber hecho “común acá mi suerte”. Y, finalmente, compartir lejos de las contingencias del mundo: "sin temer castigo / de fortuna, de amor, de tiempo y muerte". En los tres sonetos LV, LVI y LVII el sujeto se autofigura con una relación temporal constante. El tiempo se vuelve un elemento de reflexión en sí mismo pues es responsable de la fugacidad del paso por la vida terrestre; asimismo la muerte tiene una dimensión temporal en tanto es el fin de ese camino y la ruptura con el mundo material. A diferencia de los sonetos LV y LVI, aunque en los cuartetos se plantea una condición negativa del yo, en los tercetos se resuelve de manera positiva. Para Carlos Ruiz Silva:

[...] la idealización, el platonismo que respiran los tercetos, no menos la sensación de pureza y limpio gozo que desprenden, no sólo compensan la desesperanza y la angustia de los cuartetos sino que representan el triunfo final de la amistad sobre el dolor y la muerte. (216) 
Si bien el sujeto de la enunciación no se encuentra fuera de su presente en la vida terrenal, es fundamental el movimiento de ascensión que promueve la esperanza y el consuelo fuera de esta vida.

En adelante, el soneto LXI ha sido agrupado por la crítica junto a los tres sonetos anteriores por la relación con los sentimientos de crisis y desengaño. Lara Garrido, por su parte, lo separa de los anteriores en su edición (1985), como advertimos en la numeración; lo mismo hace Miguel Ángel García en su estudio "Hacia la quietud celeste: los sonetos existenciales de Francisco de Aldana".

En fin, en fin, tras tanto andar muriendo, tras tanto variar vida y destino, tras tanto, de uno en otro desatino, pensar todo apretar, nada cogiendo,

tras tanto acá y allá, yendo y viniendo cual sin aliento inútil peregrino, ¡oh, Dios!, tras tanto error del buen camino, yo mismo de mi mal ministro siendo,

hallo, en fin, que morir en la memoria del mundo es lo mejor que de él se asconde, pues es la paga dél muerte y olvido,

y en un rincón vivir con la vitoria de sí, puesto el querer tan sólo adonde es premio el mismo Dios de lo servido.

Así también lo hace Rivers y considera en Francisco de Aldana, el Divino Capitán lo siguiente:

[...] Los tres primeros responden a un determinado estado de ánimo proveniente de un conflicto interior de muy hondas raíces [...] Hay datos biográficos que pueden constituir 
fuentes probables de las que se derivara este conflicto: para Aldana, cuya juventud discurrió en el ambiente neoplatónico y medio pagano de la intelectualidad florentina y constituyó una vida idílica, sensual y filosófica a la vez, el ejercicio de la profesión militar en los Países Bajos fue un cambio brusco y nada agradable [...] podemos imaginarnos en Aldana el conflicto subconsciente entre, de un lado, los ideales italianos de cultura y refinamiento neoplatónicos, y, de otro, los españoles de Dios, Iglesia e Imperio; entre la gloria mundana y la humildad cristiana. Este último soneto, por su parte, llega a la resolución moderadamente ascética de este conflicto y a la dedicación de su espíritu a la contemplación de Dios. Así, parece marcar el principio de una nueva etapa en la vida del poeta, la etapa que produjo aquella Carta para Arias Montano. (518-520)

Al partir del análisis de Rivers, en este soneto se disponen las claves con las que el yo aparecerá en la Carta para Arias Montano. El eje de este soneto tiene su origen en el desengaño del sujeto y en el conflicto entre realidad y deseo; en contraposición, aquí sí se consigue cierto reposo de la vida fatigosa. Independientemente de la agrupación de la crítica, se advierte la resolución de la crisis a través del desengaño del mundo y la contemplación de Dios, y se supera el sufrimiento del alma encadenada al cuerpo.

Lara Garrido considera que este soneto "contrapone el infernal movimiento al deseado retorno celeste, la quietud negada a la paz eterna” (“Introducción”, 391). Más aún, este movimiento se expresa desde la anáfora de las locuciones adverbiales "En fin, en fin" con las que comienza el soneto: el yo llega a este momento de la enunciación tras una crisis interior que se expone, en seguida, en los dos cuartetos. La estructura del soneto imprime la contundencia de la conclusión en el primer terceto: "Hallo, en fin, que morir en la memoria" (énfasis mío).

En los cuartetos, el yo lírico reflexiona sobre su experiencia vital, concebida como camino en tránsito hacia la muerte en ese "andar muriendo". Al igual que en los sonetos LV, LVI y LVII, el movimiento del mundo exterior e interior se vuelve fundamental para el yo, 
quien se ciñe a su situación vital: su existencia es un "andar muriendo", un "variar [de] vida y destino", un “acá y allá yendo y viniendo". De manera similar al soneto LVII, el yo atraviesa la existencia de "tierra en tierra". La sensación de movimiento se intensifica por los verbos variar, andar, ir y venir, pero en este caso el camino lo elige el sujeto, no el destino ni la voluntad inerte, pues reconoce que ha sido el "mal ministro" de sí mismo y ha errado del “buen camino". No obstante, de nuevo el yo se presenta como peregrino.

Una diferencia medular de los conceptos trabajados en los sonetos LV, LVI y LVII frente al soneto LXI es que hay una posibilidad, antes de la muerte, para retirarse de la vida mundana: "morir en la memoria / del mundo" [...] "y en un rincón vivir con la vitoria / de sí”. Es una muerte simbólica que difiere del "andar muriendo" perpetuo del sujeto lírico en los sonetos anteriores. Por otro lado, específicamente difiere del soneto LVII en la medida en que ya no es el destino agente el que arroja al yo sino es éste mismo responsable de errar en su camino que, siguiendo el proceso de escritura como se expuso desde el capítulo anterior, podría bien corresponder a la vida cortesana y militar, aunque el soneto únicamente refiera a renunciar los bienes terrenales.

Sánchez Mairal argumenta que:

Se expone, pues, el beatus ille a lo divino, poniendo el énfasis no tanto en el retiro del mundo y el alivio espiritual que supone como en la idea de acercarse a Dios mediante la contemplación y la dirección del afecto hacia Él. Encontramos un marcado componente estoico (inherente, por otra parte, a la conformación renacentista del beatus ille) en la idea de la «victoria de sí», es decir, el sobreponerse a las aspiraciones y los deseos propios (conectados con el mundo terrenal) para anhelar tan sólo la vida retirada, donde las buenas acciones (o la ausencia de malas) y la contemplación de Dios aseguran el retorno al cielo tras la muerte. (19) 
Por otro lado, Lara Garrido interpreta que "este soneto representa el momento de la propia decisión, recogiendo en la cláusula conclusiva la experiencia pasada [...] para conducir el futuro al aquietamiento recompensado por Dios con su presencia" (Poesías castellanas completas, 429). Para este trabajo, no consideramos que es un punto de inflexión en la poética de Aldana, sino un punto de llegada en el que el yo abandona el mundo exterior y desemboca en la necesidad de llevar una vida retirada.

Miguel Ángel García explica que:

[...] la imagen de la vida como peregrinación inútil, por no haber sido hecha con vistas a Dios, permite interpretar esas acciones tantas veces experimentadas (andar muriendo, ir y venir) fuera del contexto de la milicia, de una forma mucho más general y desnuda, propia de quien se confiesa a sí mismo y hace examen de conciencia. En este sentido cualquier acción humana/mundana, y no sólo la militar, habría supuesto extraviarse del ‘buen camino' que ha de seguir el alma, habría repercutido en que el yo se administrase mal a sí mismo. De igual manera, la muerte y el olvido como paga del mundo no tienen por qué reducirse a la muerte en la guerra y al olvido como desplazamiento o sustituto final de la gloria del soldado. Es que el desequilibrio existente entre la vida según Dios o la vida según la vanidad del mundo sólo puede deparar que este pague, a quien a él se entrega, con muerte y con olvido. (648)

El yo lírico define su existencia misma como un "andar muriendo". En cualquier caso, la crítica coincide en advertir en este soneto la resolución del conflicto interior del sujeto en la aspiración a la vida retirada y el rechazo de las cosas mundanas, que culmina su desarrollo en la "Carta para Arias Montano" en la que se hará referencia explícita a la vida de soldado.

\subsection{El desengaño del mundo}

La preocupación por el hombre se advierte en toda la poesía del Aldana, pero singularmente en ciertos poemas en los que se debate entre su ser individual y social. La 
autofiguración de este sujeto profundamente preocupado por su existencia en la Tierra es fundamental para comprender su inmersión en una realidad en la que se ve obligado a participar. Asimismo el yo lírico proyecta, al discurrir entre los versos, un viaje que termina siendo tormentoso e incierto, que siempre concluye con la muerte. Por lo demás, el yo se autofigura en relación a elementos espaciales: el espacio que el hombre habita en el desarrollo de su existencia humana se asimila a un lugar triste y desechable, y el yo anhela el paraíso terrenal (locus amoenus/ beatus ille) y el paraíso celestial.

Ciertos espacios de la naturaleza van a configurar a un sujeto desengañado del mundo. En el poema XLVI (Carta al Señor Don Bernardino de Mendoza), el yo lírico naufraga en un mar:

¡Oh venturoso tú, que allá tan alto, por do rompiendo va nuestro navío, tan lejos deste mar tempestuoso, habitas y por término y tan casto, tan fuera el corporal uso del hombre, buscas a Dios y en Dios todo lo cierto! (vv. 156-161)

Dolores González Martínez analiza que esta imagen es interesante en tanto asemeja el alma a un navío, y que ocurre a lo largo de otros poemas con un significado diferente (como en el poema L). En este caso, nos dice, "el alma que huye de la mar tempestuosa, del mundanal ruido, navega con rumbo fijo, como un navío que, tras superar infinitos obstáculos, se dirige a la búsqueda de la verdad en Dios" (53).

Muchas veces nos da la sensación de que el alma es el sujeto que discurre por este espacio, como una subjetividad ya escindida del cuerpo, pues es ésta la que huye y navega en el espacio marítimo. Es evidente que a través de esta autofiguración del sujeto enunciante en el espacio, se pueda localizar al yo lírico que naufraga, y esta imagen se relaciona 
directamente con el pensamiento del autor: un alma que debe escindirse de lo corporal, y que debe navegar hasta llegar a un allá "tan lejos deste mar tempestuoso". El camino del "aquí" es un mar agitado que se contrapone con un "más allá" del alma, en donde está Dios. El alma debe atravesar este camino espacial para buscar a Dios. En cuanto a otros elementos atmosféricos que inciden en la configuración del sujeto habría que considerar no sólo el mar, sino los arroyos o ríos, la montaña, el valle, la caverna, el desierto, el cielo. En el poema L (Carta a Galanio) también hay un mar con las fuertes olas, que se asemejan a cumbres, y se aúnan al dolor del yo.

El hombre que se configura en la poesía de Aldana se acerca a lo humano, a lo temporal, a lo concreto, y su huida de la realidad a menudo responde a la fuerza con la que enfrenta su humanidad. En el poema LXV (Carta para Arias Montano):

Mas ¡ay de mí!, que voy hacia el profundo

do no se entiende suelo ni ribera, y si no vuelvo atrás, me anego y hundo.

No más allá; si puedo, aunque lo quiera.

Do la vista alcanzó, llegó la mano; ya se les cierra a entrambos la carrera. (vv. 277-282)

En esta misma carta, el yo lírico se lanza a la búsqueda de lo absoluto en un espacio indeterminado y relacionado con la infinidad, hacia una orilla en la que busca asirse: "Más pues, Montano, va mi navecilla / corriendo este gran mar con suelta vela, / hacia la infinidad buscando orilla (vv. 124-126).

La reflexión del yo por el tiempo a través de su discurrir nostálgico en el poema LXIII, claramente identifica al pasado con el espacio de la primavera; por otro lado, el espacio que 
configura el presente del sujeto (que es el mismo que se puede rastrear en el poema LXV) es el invierno.

Eterno Sol ya la encendida lumbre

do esté mi alegre abril florido y tierno

muere, y ver pienso al más nevado invierno

más verde la raíz de su costumbre (vv. 5-8)

Retomando el poema LVII se puede observar que el hombre se mueve dinámicamente y recibe los golpes del destino. Aquí, el destino es un sujeto agente que arroja al hombre en un espacio de abyección:

El ímpetu cruel de mi destino,

¡cómo me arroja miserablemente

de tierra en tierra, de una en otra gente,

cerrando a mi quietud siempre el camino! (vv. 1-4)

El espacio de la Tierra se constituye como un espacio horizontal, un camino que no asciende ni desciende, y que únicamente mantiene al yo alejado de la verdadera paz y quietud.

En este soneto, tras el deíctico mi se asume el yo lírico arrojado de tierra en tierra como parte de su destino. Su transitar por el espacio es miserable y doloroso, pues se ve obligado a peregrinar y pasar de gente en gente sin poder llegar a la ansiada quietud. Es un espacio bélico, de una guerra inacabable que no permite alcanzar el sosiego. En el segundo cuarteto se introduce un contraste respecto al primero: el yo aparece tras un "si" condicional que expresa un mal que permanece y es continuo, y que cubre al alma. El "mal grave y contino" se materializa y ejerce un "velo mísero" sobre el alma, que es exhortada a volver a la región de donde vino. De tal manera, se expresa un anhelo de huida de corte platónico, hacia el origen del alma. Este vuelo comprende una escisión del plano horizontal del camino al que se ve condenado el yo. En el primer terceto hay una nostalgia marcada por la 
invocación del "caro y dulce amigo" para emprender el viaje por el terreno celeste. El cielo se convierte en un espacio que restaurará el destierro de su alma en compañía del amigo que en tierra compartió su suerte.

El espacio celestial, un espacio abierto y opuesto a la monstruosidad terrenal en la que el sujeto lírico se presenta en soledad, peregrinando de tierra en tierra, se convierte en el espacio de la esperanza para unirse en compañía de otro. Se pregunta por las cosas que le diría y termina con un tono ascendente: "de fortuna, de amor, de tiempo y muerte", que encarnan las heridas del poeta en su peregrinación por la tierra.

En contraste, también se configura un espacio vertical que es el espacio de la divinidad. Si bien sus propiedades son ser infinito e inmenso, para expresar esto en una imagen, Aldana recurre al espacio fuera de los linderos de la Tierra: la esfera del Sol es comparada con Dios. En realidad es un símil, mediante el cual la divinidad adquiere las virtudes y propiedades del Sol: ilumina la tierra, da calor, quita la oscuridad, etc. Por otro lado, también sus cualidades de bondad se equiparan a un espacio: un abismo sin suelo. En el poema XLIII (Parto de la virgen) ${ }^{15}$ :

[...] En quien hace unidad todo lo bueno del bien particular de cada uno, no como bien por sí de bienes lleno como de todo humor vaso es Neptuno, mas como bien que es centro, abismo y seno él de sí mismo, solo, único y uno, de quien toda bondad sale influyendo en Dios, cuanto él es Dios, Dios mismo siendo. (vv. 649-656)

\footnotetext{
${ }^{15}$ Únicamente se conservan 26 octavas.
} 
Nuevamente el yo se siente expatriado de este lugar, que es su verdadera ciudad de origen. El sujeto de la enunciación se encadena a la imagen del espacio celeste, que termina siendo un espacio metafísico. El alma que le pertenece al yo también es, en realidad, ciudadana de este espacio intangible, como se observa asimismo en el poema XLIII: "Favoreced mi lira y contrapunto, / almas del cielo impírio ciudadanas" (vv. 17-18). No obstante, este cielo tiene un contrapunto de tristeza y dolor: "sembrando esterilísima simiente / en este de dolor lloroso valle (vv. 43-44).

El tratamiento del alma del yo en este canto corresponde a su aparición en dos espacios. El primero, inmaterial y vertical; el segundo, el valle, termina siento un espacio horizontal en la Tierra, que se contrapone al primero en la medida en que prevalece la desesperanza y el dolor. De manera análoga, en muchos momentos del proyecto poético de Aldana, el yo lírico debe desprenderse de todo lo corpóreo y de todo aquello que lo encadena al naufragio de la vida terrestre.

En el poema LXV (la carta para Montano) y XXXI (Sobre el bien de la vida retirada) existe una esperanza para el yo en el espacio de la naturaleza, ahora como un lugar de refugio. Según Cosme, este poema aún lo escribe en Florencia, antes de marchar a la guerra en Flandes. Como ejemplo:

Aquí me estoy en libertad, gozando, con dos amigos y un conforme hermano, aquella dulce paz que deseando está naturalmente el pecho humano; un ángel nuestras almas concertando va con juicio alto y soberano, y mezcla en tal quietud tan alto modo que en nosotros la parte es parte y todo. 
Goza de este edificio alto y pomposo que va subiendo a la región del fuego, viste de aljófar claro y muy precioso; muy lleno de ambición, perdido y ciego, de infinidad de mundos codicioso, turba la paz, mueve la guerra, y luego señala tu poder en toda parte, dañando con industria, engaños y arte. (vv. 25-40)

Por lo demás, hay una caracterización espacial constante, en la que se evoca a Esparta y a Roma (vv. 17), hay en la segunda estrofa una alusión al feudo antes del Siglo de Oro, la configuración del Paraíso del que emana la Verdad en la tercera estrofa, el edificio alto y pomposo, el aljófar; y más adelante:

Fundo mi habitación en valle amena, Sobre alta piedra en un cimiento firme, Huyo la cumbre y la movible arena, Do el rayo celestial pueda herirme; (vv. 57-60)

Este paisaje, tan anhelado por el yo, está caracterizado por el monte, el páramo, el desierto, la cumbre, la caverna, como se observa en el poema XLVI citado con anterioridad:

Vanse los tales, hecho el fuerte golpe, lejos del trato del común trafago, y lejos de ésta al fin

[...]

$\mathrm{Y}$, desdeñando pensamientos viles, indinos de su ser, buscan el bosque, buscan el monte, páramo y desierto, buscan cumbre al cielo más vecina, en cuyos cavernosos escondrijos, entre los cerriones de mil años, vive el silencio con helada lengua. 
Aquí reciben la desnuda tierra

y el estéril sarmiento por reposo,

aquí quieren pasar las breves horas

deste del alma temporal destierro. (vv. 120-134)

Este tipo de paisaje, por lo demás, no busca el deleite de los sentidos, sino que es un lugar para retirarse y precisamente, despojar al alma del cuerpo.

Regresando al poema XXXI se puede ver que este lugar se expresa mediante marcas espaciales que sitúan al yo en las orillas del mar:

[...] la mar profunda aquí enfrenada veo,

obediente al señor del firmamento

do un aire fresco y dulce a maravilla

las ondas va encrespando por la orilla. (vv. 85-88)

También en el poema LXV (Carta para Arias Montano) se describe de manera más precisa el monte Urgull y la playa de la ciudad de San Sebastián. El mar, por tanto, ya adquiere una carga semántica muy importante. En este mismo poema hay una introspección del yo que igualmente tiene una caracterización espacial: es un continente perdido y desconocido, en la profundidad del hombre. Esta comparación se puede trazar también con el continente del Nuevo Mundo, como si éste existiera de manera análoga en su interior.

Por otro lado, se puede decir que toda la poesía de Aldana está en búsqueda de un lugar que sea, al fin, adecuado para la existencia. Por ello, el yo transita por los espacios de la corte y de la ciudad, e incluso de la vida retirada, y los desestima porque ninguno es adecuado para la realización del hombre. Como se puede ver de nuevo en el poema XLVI (Carta al señor Don Bernardino de Mendoza)

Aquí reciben la desnuda tierra y el estéril sarmiento por reposo, 
aquí quieren pasar las breves horas

deste del alma temporal destierro, (vv. 31-34)

En los poemas de madurez como LV, LVI, LXI, esta existencia terrenal es desdeñada. Por el contrario, en el poema LXII, el espacio del cielo sí es caracterizado como un espacio de luminosidad y esperanza, y el único que puede sacar al yo lírico de su existencia mezquina. Además se describe como una superficie lisa y como un techo que cubre el espacio "más acá" de la Tierra.

En el soneto LXII (Al cielo) se resalta la luminosidad del "patrio cielo", en donde el cuerpo glorioso está lejos del mortal caduco velo. El alma peregrina, encerrada en su cárcel, le llora a la patria amada. Esta contraposición de dos lugares se advierte mediante la localización del sujeto, a través de adverbios de lugar que funcionan como deícticos: aquí, acá, allí, allá, lejos, cerca, etc. El acá siempre es la tempestad, el suelo, y el cuerpo, y el allá no sólo es el cielo, sino la ciudad de la infancia (Florencia), o el espacio terrenal del poema LXV.

De la misma manera, estas marcas deícticas contraponen el allá interno, la profundidad de los cimientos del alma, con el acá de la vida presente del hombre. Esta contraposición se puede ver en el soneto V frente al soneto XVIII. En el soneto V (Es tanto el bien que derramó mi seno):

Más paréceme ver que el mortal velo, no consintiendo al mal nuevo aposento, lo guarda allá en su centro el más profundo;

sea, pues, así: que el cuerpo acá en el suelo posea su mal, y al postrimero aliento gócelo el alma y pase a nuevo mundo. (vv. 9-14) 
En el XVIII (Cuál es la causa mi Damón...):

«Amor, mi Filis bella, que allá dentro

nuestras almas juntó, quiere en su fragua

Los cuerpos ajuntar también, tan fuerte

Que no pudiendo, como esponja el agua,

Pasar del alma al dulce amado entro,

Llora el velo mortal su avara suerte〉. (vv. 9-14)

Por otro lado, en el poema XXXV, el deíctico "aquí" refiere a un lugar específico: a Flandes, y se opone al “allá” de Florencia. Claramente el “aquí” del poeta está cargado de un sentido de pesadez y nostalgia. Lo que es interesante es que coexisten referencias tanto a espacios indeterminados, que pueden incluso volverse trascendentes (como el mar y el cielo), y espacios locativos determinados. La importancia de esta coexistencia radica en el anclaje histórico de la poesía de Aldana.

En el soneto LV, el yo se coloca alienado del espacio celestial, al que no puede aspirar porque la muerte aún tarda en llegar: “Cuanto en mí hallo es maldición que alcanza, / muerte que tarda, llanto inconsolable, / desdén del cielo, error de la ventura" (vv. 12-14).

O en el soneto LVI, igualmente se coloca en referencia al "bajo punto" y su cuerpo, asido a la existencia terrenal debe sostener una vida fatigosa:

¡Ay, que considerar el bajo punto

Del estado mortal al alma hiere!,

Mas del tal peso alienta y la requiere

Alta contemplación de su trasunto

$[\ldots]$

No sé si, al sostener la fatigosa

Vida, fuera mejor falto juicio,

Con que el dolor se engaña y no se siente, (vv. 1-11) 
Por lo demás, el soneto LV puede detallar la mirada subjetiva del yo que enuncia desde el espacio que habita. Quizá este soneto sea de tanta fuerza estética debido a la fuerza contrastiva entre los verbos "callar", "romper", “mover", "yacer", "hallar". Como se mencionó en el anterior apartado, estos verbos refieren a una instancia de movimiento del sujeto, de lucha y de viaje, pero en constante conflicto. Esa búsqueda de lo no hallado termina aniquilando al yo, que se condena como un “desdén del cielo”. La escisión que sufre el sujeto y que se aúna a los lugares terrenales por los que transita, tiene como consecuencia una violencia que marca cualquier forma de su existencia.

No halla la memoria o la esperanza rastro de imagen dulce y deleitable con que la voluntad viva segura.

Cuanto en mí hallo es maldición que alcanza, muerte que tarda, llanto inconsolable desdén del cielo, error de la ventura. (vv. 9-14)

El yo intenta transmitir algo que trasciende a la palabra y a los sonidos, pues es una crisis vital que no alcanza a ser representada ni por el lenguaje ni por nada que se encuentre dentro de la existencia terrenal. Ahí surge el espacio intersticial del silencio, que es alegóricamente el espacio entre la vida y la muerte. Este poema evoca un espacio metafísico que desvela una crisis espiritual: cada verso traza una línea entre la materialidad y entre la mortalidad, a partir del silencio que se dispone desde el verbo "callar" del primer verso. El lugar del silencio y de la quietud corresponde, por tanto, a la muerte que despojaría al sujeto de la enunciación de todo lo material, incluso del lenguaje que no alcanza a trascender en el espacio metafísico. 
La unión accidental entre alma y pensamiento desvela una división entre lo sensible, que tiene que ver con el espacio lunar, y lo que atañe al conocimiento, simbólicamente solar. Por ello, en el primer cuarteto se describe el impulso sensible a partir de la intención del yo lírico de "romper el cielo a gritos". Romper un espacio mediante la palabra, que es la palabra misma del poema que calla porque se impone un silencio. La proyección vertical, de ascenso contra el cielo, dispone esta primera imagen negativa; no obstante, en esa misma estrofa "por dar voz y movimiento" se opone a ese afán destructor y más bien nos arroja a una imagen ordenadora.

El yo se disuelve en el "romper el cielo a gritos", mientras que "tentar a mover la lengua" funciona como el descenso a lo tangible, a lo corpóreo de la escritura y de la persona. Quizá también en el “mil veces callo” la palabra se convierte en una agonía para escapar de la forma, para diluirse en el espacio, y finalmente implica la disolución de la identidad del hablante.

En el segundo cuarteto, el pensamiento implica una suerte de descenso pero a un espacio interior: es un viaje que se hunde en las entrañas, y se puede identificar con el descenso al Infierno. Este espacio se proyecta mediante la imaginación mítica: es el mito de Orfeo que desencadena el viaje simbólico y el fracaso trágico.

Anda cual velocísimo correo, por dentro el alma, el suelto pensamiento, con alto y de dolor lloroso acento, casi en sombra de muerte un nuevo Orfeo. (vv. 5-8)

La autofiguración ocurre tras los despliegues anteriores y la proyección del mito. El primer verso arroja al sujeto a la sima de la altura, se eleva en un vuelo vertiginoso; posteriormente, ante la imposibilidad de gritar, desciende súbitamente y termina en la muerte 
de la palabra. El contraste entre "romper deseo / el cielo a gritos" (vv. 1-2) y "en mortal silencio yacer la veo" (v. 4), funciona como una imagen de la crisis vital del sujeto poético.

El soneto LXI revisado en el apartado anterior, cargado de potencia épica y de sonoridad expresada mediante las anáforas "tras tanto", comienza una vez más con una imposibilidad. La locución "en fin" supone en la escritura la conclusión de algo previo, de una vida desdichada que más adelante se explica: un movimiento sin meta a partir de verbos como "andar muriendo", "variar vida y destino". Por lo demás, "andar muriendo" es una consecuencia del terrible y continuado proceso de "andar" que parce no tener fin. Ahora bien, ese andar se localiza en una vida "acá y allá / yendo y viniendo" que son marcas deícticas de un viaje por el mundo en busca de una trascendencia. En el segundo cuarteto hay un reconocimiento de la culpa en esa mirada al exterior que traza el sujeto poético. Posteriormente, en la cuarta estrofa aparece el espacio del "rincón", que es un pequeño espacio interior en el que el yo se refugia en busca de paz. La mirada del sujeto oscila entre el movimiento y la quietud, entre un espacio externo, abierto y vertiginoso, y un espacio cerrado, pequeño y solo.

En fin, en fin, tras tanto andar muriendo, tras tanto variar vida y destino, tras tanto, de uno en otro desatino, pensar todo apretar, nada cogiendo,

tras tanto acá y allá, yendo y viniendo cual sin aliento inútil peregrino, ¡oh, Dios!, tras tanto error del buen camino, yo mismo de mi mal ministro siendo, hallo, en fin, que morir en la memoria del mundo es lo mejor que de él se asconde, 
pues es la paga dél muerte y olvido,

y en un rincón vivir con la vitoria

de sí, puesto el querer tan sólo adonde

es premio el mismo Dios de lo servido.

Los dos primeros cuartetos arrastran la mirada hacia un pasado desordenado mediante un movimiento caótico, y un retorno al presente de la enunciación del sujeto lírico, ya insatisfecho. Este poema encadena el espacio con el tiempo mediante el deslizamiento que permiten las locuciones "en fin" y "tras tanto", que ofrecen un desplazamiento del espacio en el tiempo. El discurrir se articula mediante la mirada que se erige sobre tres claves espaciotemporales: "memoria", “esconder” y "rincón”. En este soneto, de manera contundente, tras una serie de aliteraciones, se rechaza la existencia mundana: "yo mismo de mi mal ministro siendo [...] hallo, en fin, que morir en la memoria del mundo es lo mejor que en él se asconde, pues es la paga dél muerte y olvido”.

Nuevamente, el soneto LVI expresa desde un principio una marcada disposición de búsqueda que parte de una queja del yo poético y una exhortación a considerar el "bajo punto / del estado mortal". Se localiza el estado mortal en un espacio inferior, desde el cual se despliega una experiencia vital y una reflexión sobre la escritura, que están íntimamente relacionadas.

La vida amorosa y militar constituyen el juego retórico del poema. Estructuralmente el primer cuarteto comienza con una sombra que se extiende por el resto del poema. Es una sombra trágica que implica la sujeción del alma al cuerpo mortal, y el cuerpo-microcosmos se erige como un espacio de cárcel. A continuación hay una oración adversativa que despliega no una acción en el mundo material, sino una acción intelectiva, de reflexión. Para llegar a 
este punto tuvo que haber existido una experiencia material y una espiritual, que se desarrolla a manera de dicotomía y que pareciera ocasionar un estado de profundo dolor en el sujeto poético. Los tercetos conforman una antítesis entre un estado de ignorancia y de sabiduría, que respectivamente generan ausencia de dolor o condenación para el sujeto poético.

En contraste, el poema LVII se erige sobre una estética de la violencia que termina por oprimir al yo. Pareciera que no es este sujeto quien se mueve, sino el espacio que se dirige hacia él y lo envuelve. En la primera estrofa se dispone todo un movimiento caótico, para alzar el vuelo hacia la sima del paraíso, en la unión del alma con el cuerpo. La violencia del espacio exterior, ese "ímpetu cruel" tiene su correlato en la ruptura del "velo mísero y doliente".

La violencia del primer cuarteto se representa por aquellos elementos de la Tierra, y que se sustituyen por una nueva tierra, el cielo. En éste aparece un amigo. Ambos espacios caracterizan a personas que se relacionan con la experiencia vital del yo. Si en el soneto LV el sujeto poético participaba de un topos en conflicto, nos encontramos ahora con un espacio de paz y sosiego debido a que hay una esperanza en el tiempo futuro. El espacio que abre este horizonte viene dado por la aparición de otro, de un amigo que aparece tras el naufragio de la vida. Ya nos encontramos con una mirada en la que el alma del yo rompe su velo y cárcel, y la voluntad poética, liberada del "estado mortal”, alcanza la plenitud mediante la expansión de su cuerpo material y temporal en el espacio celeste, un espacio metafísico.

Si en el primer cuarteto el sujeto poético está alienado y se siente maltratado por una circunstancia que lo desborda en el "ser arrojado", el segundo cuarteto logra que el alma se disuelva en el espacio divino "tras tanto mal, grave y contino", que es el espacio de un hogar. Así, la dialéctica entre tierra / cielo y cuerpo / alma recuperan un equilibrio tras un proceso 
de ascenso en el espacio (ese "vuelo diligente"). Finalmente en los tercetos se establece un espacio paradisiaco, alejado del "tiempo y de la muerte".

Además, se puede deducir que una de las fuentes importantes para la construcción del espacio y su ordenamiento son los astros; específicamente el sol y la luna. Los astros semantizan a los sujetos del poema, así como dotan de dinamismo o estatismo los cuadros presentados en los mismos, como se vio inicialmente en el poema LXV y XLIII. El astro se convierte en un centro organizador del espacio de la Tierra y del Universo, y comunica al hombre con Dios, como en el poema LXV (Carta a Arias Montano).

Puede del sol pequeña fuerza ardiente

Desde la tierra alzar graves vapores

A la región del aire allá eminente,

¡y tantos celestiales protectores,

Para subir a Dios alma sencilla,

Vernán a ejercitar fuerzas menores? (vv. 18-23)

Cuando el yo atraviesa los espacios logra expresar estéticamente la profunda preocupación por la vida del hombre, su existencia en la Tierra, sus decisiones morales, y su impostergable inmersión en una realidad presente efímera, pero también superficial.

En el poema XXXVIII (Pocos tercetos a una amigo) visto en el capítulo anterior, los deícticos marcan estos contrastes de manera similar. "Allá” denota el ámbito de la corte, de manera negativa (llena de vicios y placeres), mientras que "acá” designa el campo de batalla (lugar de austeridad y sacrificio).

Mientras estáis allá con tierno celo,

De oro, de seda y púrpura cubriendo

El de vuestra alma vil terrestre velo, 
Sayo de hierro acá yo estoy vistiendo,

Cota de acero, arnés, yelmo luciente,

Que un claro espejo al sol voy pareciendo.

Mientras andáis allá lascivamente,

Con flores de azahar, con agua clara,

Los pulsos refrescando, ojos y frente,

Yo de honroso sudor cubro mi cara,

Y de sangre enemiga el brazo tiño

Cuando con más furor muerte dispara. (vv. 1-12)

En general, el acá siempre se refiere a lo inmediato de la vida mundana, y el allá a lo trascendental. Estos marcadores también relacionan el acá con lo exterior y corporal del hombre, y el allá para el abismo y el continente perdido del alma. Finalmente, esos marcadores localizan al yo cuando atraviesa la batalla (y se contrapone al espacio de la corte), así como cuando se encuentra en un lugar de asilamiento, y se refiere al allá como el mundo material.

Por último, el término patria aparece cuando el alma se refiere a que ésta es el cielo. Es decir, hay una extracción semántica de este campo. Asimismo el cielo mantiene la estructura de las instituciones políticas y sociales. En este campo semántico hay sustantivos como rey, monarca, trono, palacio, corte, etc. Otros espacios que permiten la caracterización del yo son la cárcel, la prisión, o el destierro, atalaya, alcázar, etc.

\subsection{La contemplación de Dios}

Si bien ya se abordó la cuestión epistolar en el capítulo tres, con las aportaciones de Rosa Navarro Durán, es necesario retomar que la crítica adscribe la "Carta para Arias Montano" a la epístola horaciana, al igual que la epístola "Sobre el bien de la vida retirada" 
y la "Carta a don Bernardino de Mendoza". No se trata de composiciones homogéneas, sino que contienen referencias y matices diversos, dándole más importancia al estado retirado inscrito en el tópico del beatus ille. La "Carta para Arias Montano”, considerada por la crítica la obra maestra de Aldana y la culminación de su proceso poético, desarrolla también a su manera la idea de la vida retirada, poniendo el énfasis en la contemplación de Dios y en el sentimiento de experiencia compartida en la amistad en contraste con el sufrimiento en el que el yo lírico se había posicionado en su pasado, inmerso en la vida terrenal.

La carta ha tenido un gran peso en el estudio de la obra de Aldana. Vossler, en La poesía de la soledad en España, considera que "el guerrero, el humanista y el anacoreta se asocian de modo maravilloso en el espíritu de Francisco de Aldana (177). Más adelante considera la que es la mejor expresión de su deseo de soledad (y retiro acompañado de Arias Montano en esa vida apartada), no sólo como paraíso en la Tierra o Edad de Oro de carácter humanista, sino también como refugio espiritual y garantía religiosa de la pureza y la verdad en Dios (191).

Luis Cernuda, en "Tres poetas metafísicos”, parte de esta epístola para considerar a Aldana un poeta que entronca con los poetas metafísicos (109). Para Rivers es la obra maestra de Aldana en el género de la epístola horaciana:

en cuya tradición predomina la filosofía suavemente estoica de Horacio. Se trata de una tradición humanista: mientras se desdeñan algunos aspectos del mundo, los adquisitivos y ambiciosos, se estiman los moderados placeres de la vida campesina y de la amistad humana. Así, expone una filosofía personal en que se rechaza el mundo de la lucha externa y se propone como ideal una vida sosegada, llevada en retiro con el amigo a quien se dirige la carta. Pero además va más allá de lo humanista, procurando alcanzar la unión mística: es, por ende, una epístola horaciana a lo divino. (618-619) 
Para el hispanista, el poema representa una muestra del espíritu del siglo XVI español, al igual que Fray Luis de León, en cuya obra se fundieron perfectamente el humanismo del Renacimiento y el cristianismo de los místicos españoles (Rivers 622). Asimismo, la crítica señala una y otra vez la presencia de elementos autobiográficos en este poema, ya que se trata de una carta dirigida por Aldana a un destinatario real.

Para Lara Garrido, aunque rechaza gran parte de la interpretación de Cernuda quien ve en este poema la totalidad de la experiencia vital y espiritual del poeta, en la epístola convergen las líneas de su trayectoria poética (14-16). Para efectos de la autofiguración del $y$, es la "honradez" con la que expresa el sufrimiento interior en su circunstancia vital lo que interesa primordialmente. La instancia de la vida del yo que se autofigura poéticamente, en la que el autor cifra su edad al momento de la escritura, queda manifiesta en los siguientes versos: "Basta decir que cuatro veces ciento / y dos cuarenta vueltas dadas miro / del planeta seteno al firmamento" (vv. 34-36).

El sentimiento de rechazo del mundo se perfila desde los sonetos analizados en el primer apartado del capítulo, en el que el mundo terrenal es el origen del sufrimiento y del movimiento caótico de un yo desesperanzado que progresivamente, del soneto LV, en el que incluso la muerte era inalcanzable, pasa a la voluntad de rechazar la vida mundana en el soneto LXI. Cuando el yo reconoce la alternativa a la vanidad del mundo terrenal antes de la muerte, halla la quietud momentánea retirándose a la contemplación de Dios.

La epístola a Montano desarrolla esta voluntad espiritual del yo, y expone la idea de compartir dicho retiro con algún "caro y dulce" amigo. De tal manera, tras la dedicatoria inicial a Montano, el yo contempla sus experiencias de crisis y dolor:

Yo soy un hombre desvalido y solo, expuesto al duro hado cual marchita 
hoja al rigor del descortés Eolo;

mi vida temporal anda precita

dentro el infierno del común trafago

que siempre añade un mal y un bien nos quita.

Oficio militar profeso y hago,

baja condenación de mi ventura

que al alma dos infiernos da por pago.

Los huesos y la sangre que natura

me dio para vivir, no poca parte

dellos y della he dado a la locura,

mientras el pecho al desenvuelto Marte

tan libre di que sin mi daño puede,

hablando la verdad, ser muda el arte.

Y el rico galardón que se concede

a mi (llámola así), ciega porfía

es que por ciego y porfiado quede. (vv. 7-24)

Miguel Ángel García sugiere que:

[...] tras exaltar las armas desde el humanismo militar y luego desde la lógica poética de la sacralización de la política imperial en las Octavas a Juan de Austria y Felipe II, encontramos aquí una condena de las armas que se produce porque entonces la vida militar o la guerra son un perjuicio para el alma que ha emprendido la estrecha carrera de la contemplación divina. (602)

En el primer terceto, el yo lírico aparece como un "hombre desvalido y solo" expuesto al "duro hado", de manera semejante al planteamiento del soneto LVII. Además, Lara Garrido apunta que "la imagen del sujeto poético como hoja movida por el viento proviene de la reflexión agustiniana sobre cómo todos nosotros somos hoja en Las meditaciones" (Poesías castellanas completas, 438). 
Más adelante, este sujeto aparece dentro del ámbito de la guerra que se conecta con el "Diálogo entre cabeza y pie", y nuevamente se manifiesta lo carnal y visceral (vv. 16-18). No se rechazan únicamente los horrores físicos de la guerra que destruye al cuerpo, sino que se rechaza el oficio que "al alma dos infiernos da por pago". Uno de estos infiernos es el de la batalla que se describió en el poema XLV y el segundo es la condenación del alma más allá de la muerte.

Rivers concluye que "aunque primero el poeta habla de sí mismo como de una hoja al viento y parece echar la culpa a su ventura, poco a poco se va culpando más a sí mismo" (Francisco de Aldana, el divino capitán, 619).

Basta decir que cuatro veces ciento y dos cuarenta vueltas dadas miro del planeta seteno al firmamento

que en el aire común vivo y respiro, sin haber hecho más que andar haciendo yo mismo a mí, cruel, doblado tiro

y con un trasgo a brazos debatiendo que al cabo, al cabo, ¡ay Dios!, de tan gran rato mi costoso sudor queda riendo. (vv. 34-42)

El yo lírico está consciente de que la vida que ha llevado es la causa de su sufrimiento, el mismo de su "mal ministro siendo" como había expresado en el soneto LXI. En éste, el sujeto también planteó vivir en un rincón, con la victoria de sí. En la carta:

Mas ya, ¡merced del cielo!, me desato, ya rompo la esperanza lisonjera el lazo en que me asió con doble trato.

Pienso torcer de la común carrera 
que sigue el vulgo y caminar derecho

jornada de mi patria verdadera;

entrarme en el secreto de mi pecho

y platicar en él mi interior hombre,

do va, do está, si vive o qué se ha hecho.

Y porque vano error más no me asombre,

en algún alto y solitario nido

pienso enterrar mi ser, mi vida y nombre

y, como si no hubiera acá nacido,

estarme allá, cual Eco, replicando

al dulce son de Dios del alma oído. (vv. 43-57)

Este yo piensa corregir su discurrir por la existencia y "caminar derecho" para buscar su "interior hombre". Para Rivers este concepto supera el horacianismo y queda reflejado en la expresión "interior hombre" que proviene del "hombre interior" de la Epístola a los Romanos de San Pablo que entró a la literatura occidental con las Confesiones de San Agustín (Francisco de Aldana, el divino capitán 620).

El yo lírico entierra: "mi ser, mi vida y nombre" en un "alto y solitario nido", mediante lo cual quedará liberado del sufrimiento que provoca la vida mundana y se reducirá a mero "eco" del "dulce son de Dios". Esta idea queda plasmada mediante la alusión al mito de la ninfa Eco en las Metamorfosis de Ovidio. En la epístola, el yo desea ser transformado en eco de Dios, el "sobrecelestial Narciso amante" (v. 63). Se desarrolla entonces extensamente una exposición de este proceso, que conducirá al alma del yo al estado contemplativo como "eco resonante / a la eterna beldad que está llamando" (vv. 59-60). 
Por otro lado, el sujeto se imagina ese retiro del mundo en soledad compartida con Arias Montano, amigo cuyo ejemplo inspira virtud. Así, el yo lírico ansía que "juntamente contigo estar pudiese / lejos del error, de engaño y sobresalto, / como si el mundo en sí no me incluyese" (vv. 300-303). Ruiz Silva señala que:

la vida apartada, casi eremítica, la lejanía del ruido mundano, se desea, pero con la presencia del amigo, reverenciada y admirada [...] tal vez sea esta parte de la epístola la más horaciana, la que conserva una mayor relación con las epístolas, más o menos inspiradas en la mentalidad del gran poeta latino, de la literatura española, desde Garcilaso, Mendoza y Boscán hasta la “Epístola moral a Fabio". (235)

Como se ha visto, el tiempo erosiona, desgasta físicamente al hombre y sobre todo devasta su espíritu. Como se aprecia en el poema XXXI, las imágenes parten de una reflexión filosófica; en los poemas posteriores, específicamente la "Carta para Arias Montano" se reflexiona sobre la imagen de la existencia temporal de manera mucho más espontánea, atendiendo a la vanidad del mundo desde la propia experiencia. El yo afligido y abrumado ahora medita sobre la creación en general y le pide al alma que emerja para buscar a Dios. A partir de la meditación se contemplan las criaturas que son obra de Dios. Por último, el alma del sujeto reconoce que la experiencia mística es una espera y "una vez llegado a la suma natura de Dios, lugar por Él habitado, se dispone a esperar su presencia [...] se dispondrá a gozar de ella. Como si de un recipiente se tratase, el alma se verá colmada de tanta increíble belleza (González 66). El alma del yo navega a la deriva en un mar, sin rumbo fijo, dejándose llevar por la corriente que es Dios, y hasta entonces se entusiasma con lo que experimenta. Finalmente reclama la presencia del destinatario de la carta, Montano, el verdadero maestro que conoce los requisitos de la contemplación. 


\section{Conclusión}

Esta investigación reconstruye dos ejes temáticos centrales a la poética de Francisco de Aldana a partir de la reflexión en torno a la autofiguración del yo poético. En tanto herramienta teórica y analítica permitió hacer una lectura detenida de los sujetos, planos y lugares que se configuran en su poesía; ésta discurre entre las letras y las armas, entre el amor y la metafísica, e incluye poemas políticos, espirituales, religiosos y de circunstancias. El análisis de los lugares en los que se desdobla el yo permite ver el desarrollo de las imágenes líricas que codifican valores culturales y simbólicos así como rastrear las operaciones intelectuales y espirituales del sujeto de enunciación. El yo siempre es un centro desde el que se enuncian realidades terrenales o metafísicas, o desde el que se personifica la naturaleza en relación al sujeto.

El planteamiento es que los poemas del corpus contribuyen a figurar a un Aldana no como escritor empírico sino como autor textual, así como entender las condiciones de producción y recepción de su poesía. El análisis permitió reconocer una serie de elementos fundamentales para el trazado de la enunciación y así, visualizar la construcción que se brinda de la función autorial; a saber, los poemas contribuyen a la autofiguración de Aldana como escritor que complejiza la relación entre el yo empírico y el yo lírico, y oscila entre la ficción y el referente histórico.

Su originalidad radica no sólo en las condiciones materiales de su vida, sino en las formas y contenidos perfectamente adecuados, que expresan de manera contundente, en contrapunto, los espacios bélicos frente a la cortesanía renacentista, y los horrores de la guerra y de la acción militar frente al mundo retirado. Por lo demás, su poética gira alrededor 
de un eje ideológico pues recoge, en efecto, dos tradiciones: neoplatónica y petrarquista, y el legado de la escuela de Salamanca, en torno a Fray Luis de León y Benito Arias Montano.

La interpretación en conjunto de la obra de Aldana como expresión de esta subjetividad dinámica permite abundar en la poética del autor y finalmente racionalizar su proyecto poético con la distancia histórica de la presente lectura. La poesía de Aldana, en general, es fruto del deseo de resolver su problemática vital valiéndose de la palabra poética, y de ahí que ésta gire en torno a la reflexión sobre el hombre y sobre Dios, sin olvidar el aspecto afectivo y sensitivo de aquel. En definitiva, el poeta trata de explicar su naturaleza y las relaciones que mantiene con el alma con el cuerpo y con la Divinidad, así como el devenir del hombre en la Tierra. 


\section{Bibliografía}

\section{Ediciones de las obras de Francisco de Aldana (en orden cronológico)}

Primera parte de las obras que agora se han podido hallar del Capitán Francisco de Aldana, Alcayde de San Sebastian, el qual murioó peleando en la jornada de Africa... Milán, 1589.

Segunda parte de las obras, que se han podido hallar del Capitan Francisco de Aldana, Alcayde de San Sebastian, que fue Maestre de Campo General del Rey de Portugal, en la jornada de África, adonde murió peleando... Madrid, 1591.

Todas las obras que hasta agora se han podido hallar del Capitan Francisco de Aldana, Alcayde de San Sebastan, que fue Maestro de Campo General del Rey de Portugal en la jornada de Africa, a do murió peleando... Madrid, 1593.

Obras completas. 2 vols. Ed. Manuel Moragón Mestre. Madrid: Consejo Superior de Investigaciones Científicas, 1953.

Poesías. Ed. Elías Rivers. Madrid: Clásicos Castellanos, 1957.

Epistolario poético completo. Ed. Antonio Rodríguez-Moñino. Madrid: Turner, 1978.

Carta para Arias Montano, Sobre la contemplación de Dios y los requisitos della. Ed. José Lara Garrido. Málaga: Librería Rayuela, 1984.

Sonetos. Ed. Raúl Ruiz, Madrid, Hiperión, 1984.

Poesías castellanas completas. Ed. José Lara Garrido. Madrid: Cátedra, 1985.

Poesías. Ed. Rosa Navarro Duran. Barcelona: Editorial Planeta, 1994.

\section{Estudios sobre Francisco de Aldana}

Alcalá, Ángel. Epílogo. Epístola a Arias Montano. Por Ben Rekers. Madrid: Taurus, 1973.

Barbolani di Montauto, Cristina. "Las octavas de un verso español y otro toscano de Francisco de Aldana”. Paisaje, juego y multilingüismo. X simposio de la sociedad española de literatura general y comparada. (Santiago de Compostela, 18-21 de octubre de 1994). Vol. II. Universidad de Santiago de Compostela, 1996. 305-314.

Bergamín, José. "Hombre adentro” y "Las indias de Dios”. Beltenebros y otros ensayos sobre literatura española. Barcelona: Noguer, 1973. 
Blecua, Alberto, Manual de crítica textual. Literatura y Sociedad 33. Madrid: Castalia, 1983.

Blecua, José Manuel. Historia de la Literatura Española. Vol. I. Zaragoza: Librería General, 1944. Biblioteca Virtual Miguel de Cervantes. Alicante, 2011. Web

Bunes Ibarra, Miguel Ángel de y Abraham Madroñal. "Una carta jocosa inédita de Francisco de Aldana y nuevos datos para su biografía”. Revista de Filología Española 90.1 (2010): 9-46. Researchgate. Web

Byrne, Susan. El Corpus Hermeticum y tres poetas españoles: Francisco de Aldana, Fray Luis de León y San Juan de la Cruz. Conexiones léxica y semánticas entre la filosofía hermética y la poesía española del siglo XVI. Tesis doctoral. City University of New York, 2004.

Cerrón Puga, María Luisa. "Francisco de Aldana traductor de Lucrecio (sonetos XVIII y XXIX)”. Ogni onda si rinnova. Studi di ispanistica offerti a Giovanni Caravaggi. Vol. 1. Ed. Andrea Baldissera, Giuseppe Mazzochi y Paolo Pintacuda. Ibis, 2011. Cernuda, Luis. “Tres poetas metafísicos”. Bulletin of Spanish Studies 25.98 (1948): 109-118. Cervantes, Miguel de. La Galatea. Ed. Rodolfo Schevill y Adolfo Bonilla. Madrid: Imprenta de Bernardo Rodríguez, 1914. Biblioteca Virtual Miguel de Cervantes. Alicante, 2001. Web

---. Viaje del Parnaso y poesías sueltas. Ed. José Montero Reguera, Fernando Romo Feito y Macarena Cuiñas Gómez. Madrid-Barcelona: Real Academia Española: Galaxia Gutenberg, 2016.

Clocchiatti, Emilio. "Francisco de Aldana también tradujo el poema de Sannazaro". El Sannazaro español de Herrera Maldonado. Madrid: Ínsula, 1963.

Cossío, José María de. Fábulas mitológicas en España. Pról. Dámaso Alonso. Madrid: Espasa-Calpe, 1952.

Crawford, James Pyle Wickersham. "Francisco de Aldana: A Neglected Poet of the Golden Age in Spain”. Hispanic Review 7 (1939): 48-61.

Cuadrado, Jesús Hernando. El ciclo amoroso en Francisco de Aldana. Madrid: Francisco Arellano, 1981.

Cuevas, Cristóbal. "Francisco de Aldana". Fray Luis de León y la Escuela Salamantina. Madrid: Taurus, 1982. 
Ferraté, J. "Siete sonetos de Francisco de Aldana". Teoría del poema. Barcelona: Seix Barral, 1957.

Fosalba, Eugenia. "Francisco de Aldana, poeta de la presencia amorosa". Glosa: Anuario del Departamento de Filología Española y sus Didácticas 3 (1992): 179-197.

Fox, Dian. "Frente a frente: Francisco de Aldana and Sublimations of Desire". Caliope 11 (2005): 65-85

Fucilla, J.G. "Franciso y Cosme de Aldana" en Estudios sobre el petrarquismo en España. Madrid: CSIC, 1960.

Gallego Morell, Antonio. El mito de Faetón en la Literatura Española. Madrid: Consejo Superior de Investigaciones Científicas, 1961

Gamba Corradine, Jimena. "Límites entre filosofía y literatura: del tratado amoroso a la literatura bucólica". Cahiers d'études hispaniques médiévales 1.38 (2015): 117-130. Cairn.info Matières à reflexión. Web

García Aguilar, Ignacio. “Cosme edita a Francisco de Aldana: problemas de la edición póstuma”. Cánones críticos en la poesía de los Siglos de Oro. Coord. Pedro Ruiz Pérez. Vigo: Academia del Hispanismo, 2008.

García, Miguel Ángel. "Sin que la muerte al ojo estorbo sea". Nueva lectura crítica de Francisco de Aldana. Mérida: Editora Regional de Extremadura, 2010.

---. "Hacia la quietud celeste: los sonetos existenciales de Francisco de Aldana". Voz y Letra. Revista de Literatura 21.1 (2010): 3-22.

---. “'Oficio militar profeso y hago: los 'Pocos tercetos escritos a un amigo', de Francisco de Aldana". Bulletin of Hispanic Studies 89.6 (2012): 599-614.

Gil Polo, Gaspar. Primera parte de Diana enamorada. Valencia, 1564. Biblioteca Virtual Miguel de Cervantes. Alicante, 2005. Web

Gómez Canseco, Luis. Poesía y contemplación. Las «Divinas Nupcias» de Benito Arias Montano y su entorno literario. Huelva: Servicio de Publicaciones Universidad de Huelva, 2007.

González Martínez, María Dolores. "Fonosimbolismo y aliteración: Francisco de Aldana frente a la palabra poética". Scriptura 6- (1991): 41-50.

---. “La 'Carta para Arias Montano'. Génesis y análisis de la última actitud estética de Francisco de Aldana”. Estudios Hispánicos 16 (2008): 11-32. 
--- "La metamorfosis del paisaje renacentista en la poesía de Francisco de Aldana". Scriptura, IV, 1988. Pp. 9-20.

---. La poesía de Francisco de Aldana (1537-1578). Introducción al estudio de la Imagen. Edicions de la Universitat de Lleida, 1995.

---. Orfeo y Eurídice: la imagen en la poesía de Francisco de Aldana, Barcelona: Universidad Autónoma de Barcelona, 1992.

González-Molina, Oscar Javier. “El discurso amoroso en la 'Carta a Galanio’ de Francisco de Aldana”. Etiópicas. Revista de Letras Renacentistas 9 (2013): 55-74.

Green, Otis Howard. “A wedding Introito by Francisco de Aldana (1537-1578)”. Hispanic Review 31.1 (1963): 8-21. Jstor. Web

---."España y la tradición occidental”. Actas del Primer Congreso de la Asociación Internacional de Hispanistas celebrado en Oxford del 6 al 11 de septiembre de 1962. Oxford: The Dolphin Book, 1964. Biblioteca Virtual Miguel de Cervantes. Alicante, 2016. Web

---. "On Francisco de Aldana: Observations on Dr. Rivers study of El Divino Capitán". Hispanic Review 26 (1958): 117-135.

Lara Garrido, José. "Introducción”. Poesías castellanas completas. Madrid: Cátedra, 1985.

---. "Las ediciones de Francisco de Aldana: hipótesis sobre un problema bibliográfico". Revista de Estudios Extremeños 42 (1986): 541-584.

---. "Visión, alegoría y discurso en las Octavas a Felipe II de Francisco de Aldana". Nueva Revisa de Filología Hispánica 36 (1988): 277-302.

Lefebvre, Alfredo. La poesía del capitán Aldana (1537-1568). Concepción: Universidad de la Concepción, 1953.

Lennon, Paul Joseph. "Beyond Neoplatonism: Love in the Poetry of Francisco de Aldana". Tesis doctoral. University of Cambridge, 2013.

---. “'Las partes donde Amor el cetro tiene'. Uncanonical Love in Francisco de Aldana's Medoro y Angelica”. Bulletin of Spanish Studies 92.4 (2015): 507-525. Researchgate. Web

López Anglada, Luis. "Literatura y milicia. Francisco de Aldana 'El Divino"”. Revista de las Armas y Servicios. 40.479 (1979): 89-95.

Lorenzo, Pedro de. "Geografía imperial de Francisco de Aldana". Revista de 
Espiritualidad 7 (1948): 204-224

---. “La razón del Capitán Aldana". Revista Nacional de Educación 8.82 (1948): 46-50.

Luján García, Celso. "Hermenéutica de la obra de Francisco de Aldana”. La Torre del Virrey. Revista de Estudios Culturales 8 (2010): 105-109.

Martínez Góngora, Mar. "Francisco de Aldana y el rapto de Europa: entre la hibridez cultural y el triunfo sobre el Islam”. Hispanófila 173 (2015): 21-36.

Martínez López, María Josefa. "La primera redacción de las Octabas dirigidas a Felipe II De Francisco de Aldana y su inédita dedicatoria en prosa". Criticón 70 (1997): 3170.

Mateos Paramio, Alfredo. "Francisco de Aldana: Un neoplatónico del amor humano?". Estado actual de los estudios sobre el Siglo de Oro. Actas del II Congreso Internacional de Hispanistas del Siglo de Oro. Vol. II. Coord. Manuel García Martin. Salamanca: Universidad de Salamanca, Ediciones Universidad de Salamanca, 1993. 657-662.

Mazzocchi, Giuseppe. "Lo burlesco Religioso: la Canción a Cristo crucificado, de Francisco de Aldana". Tiempo de burlas. En torno a la literatura burlesca del siglo de oro. Eds. Javier Huerta Calvo, Emilio Peral Vega y Jesús Ponce Cárdenas. Madrid, 2001.

Menéndez Pelayo, Marcelino. Estudios y discursos de crítica histórica y literaria.

Humanistas, lírica, teatro anterior a Lope. Ed. Enrique Sánchez Reyes. Madrid: Consejo Superior de Investigaciones Científicas, 1942. Biblioteca Virtual Miguel de Cervantes. Alicante, 2008. Web

---. Historia de las ideas estéticas en España. Siglos XVI y XVII. Ed. Enrique Sánchez Reyes. ". Madrid: Consejo Superior de Investigaciones Científicas, 1940. Biblioteca Virtual Miguel de Cervantes. Alicante, 2008. Web

---.Horacio en España. Tomo II. $2^{\text {a }}$ ed. Madrid, 1885. UANL. Web

Miguel, Álvaro Alonso. “Las 'Octavas sobre la creación del mundo' de Francisco de Aldana". Rumbos del hispanismo en el umbral del cincuentenario de la AIH. Coord. y ed. Patrizia Botta. Vol. III. Roma: Bagatto Libri, 2012. Centro Virtual Cervantes. Web

Navarro Duran, Rosa. “Introducción”. Francisco de Aldana. Poesías. Barcelona: Editorial Planeta, 1994.

---. "Las epístolas de Francisco de Aldana: diversificaciones del canon". La epístola. 
Sevilla: Universidad de Sevilla, 2000.

Nievas Rojas, Adalid. "La amistad en la poesía de Francisco de Aldana”. Studia

Aurea. Revista de Literatura Española y Teoría Literaria del Renacimiento y Siglo de Oro 10 (2016): 411-443.

Pintacuda, Paolo. "Dos ejemplares desconocidos de las últimas ediciones sine notis de las 'Obras' de Francisco de Aldana”. Analecta Malacitana 28.2 (2005): 483-502.

Prieto de Paula, Ángel L. "Filología y razón dialogística en los sonetos amorosos de Aldana". Parnaso de dos mundos: de literatura española e hispanoamericana en el Siglo de Oro. Ed. José María Ferri Coll y José Carlos Rovira. Madrid: Iberoamericana, 2010.

Rivers, Elías Lynch. "A New Manuscript of a Poem hitherto attributed to Fray Luis de León”. Hispanic Review 20 (1952): 153-158.

--. Francisco de Aldana, el divino capitán. Badajoz: Diputación Provincial de Badajoz, 1955.

---. "Introducción”. Poesías. Francisco de Aldana. Ed. Elías L. Rivers. Madrid: Espasa Calpe (Clásicos Castellanos), 1957.

---. "New Biographical Data on Francisco de Aldana”. Romanic Review 14 (1953): 166184.

Rodríguez Moñino, Antonio. "Noticia preliminar”. Epistolario completo. Francisco de Aldana. Badajoz: Diputación Provincial de Badajoz, 1946.

Rojas Loa Salazar, Valentina. "Presencia y análisis de los elementos filosóficos Renacentistas en la poesía de Francisco de Aldana". Tesis de licenciatura dirigida por Aurelio González Pérez. UNAM, 2012.

Ruiz Silva, Carlos. Estudios sobre Francisco de Aldana. Valladolid: Universidad de Valladolid, 1981.

Salstad, M. Louise. "Francisco de Aldana's Metamorphoses of the Circle". The Modern Language Review 74 (1979): 599-606.

Sánchez Mairal, Claudia. "La crisis del sujeto poético en Francisco de Aldana: desengaño del mundo y contemplación de Dios”. Tesis. Universidad de Zaragoza, 2014.

Sebold, Russell P. "Francisco de Aldana: su lucha existencial ante 'la risa de su llanto"”, 
Salina: revista de Lletres 20 (2006): 81-90. Biblioteca Virtual Miguel de Cervantes.

Suárez Diez, José Ma. "El otoño del Renacimiento: poética de madurez en cuatro sonetos de Francisco de Aldana”. Lemir 13 (2009): 177-190.

Torres Salinas, Ginés, La luz en la poesía española del siglo XVI (Garcilaso, fray Luis, Aldana y Herrera). Tesis doctoral. Universidad de Granada, 2013.

Vilanova, Antonio. "Preceptistas españoles de los siglos XVI y XVII". Historia general de las literatura hispánica. Tomo III. Ed. E. Díaz-Plaja. Barcelona: Editorial Barna, 1953.

Vossler, Karl. La poesía de la soledad en España. Buenos Aires: Losada, 1946.

Walters, David Gareth. The poetry of Francisco de Aldana. Londres: Tamesis Books, 1988.

\section{Estudios sobre autofiguración}

Agamben, Giorgio. “The Author as Gesture.” Profanations. New York: Zone, 2007.

Barthes, Roland. "La muerte del autor". El susurro del lenguaje. Más allá de la palabra y la escritura. Barcelona: Paidós, 1987.

Benveniste, Emile. Problemas de lingüística general. Vol I. Buenos Aires: Siglo XXI, 2007.

Blanchot, Maurice. El espacio literario. Barcelona: Paidós, 2004.

Eakin, Paul. How our Lives Become Stories. Making selves. Ithaca: Cornell UP, 1999.

Espinoza Elías, Diana Alejandra. "El sujeto enunciador lírico: aproximaciones a su problemática”. Escritos. Revista del Centro de Ciencias del Lenguaje 33.1 (2006): 65-77.

Filinich, María Isabel. Enunciación. Buenos Aires: EUDEBA, Instituto de Lingüística, 1999.

Foucault, Michel. "What is an author?” Trad. Donald Bouchard y Sherry Simon. Ed. Seán Burke. Authorship. From Plato to the Postmodern. Edinburgh: Edinburgh UP, 1995.

Gasparini, Philippe. Autofiction: une aventure du langage. París: Seuil, 2008.

Gusdorf, Georges. "Conditions and Limits of Autobiography”. Autobiography. Essays Theoretical and Critical. Ed. James Olney. Princeton: Princeton UP, 1980. 
Maccioni, Franca. “'Soy literatura'. Tensiones entre biografía y biografema, en Roland Barthes según él mismo". Boletín GEC 16. (2012): 229-233. UNCU. Web

Pimentel, Luz Aurora. El relato en perspectiva. Estudio de teoría narrativa. $4^{\mathrm{a}}$ ed. México: Siglo XXI editores, 2008.

Pozuelo Yvancos, José María. “Enunciación lírica?”. Teoría del poema: la enunciación lírica. Amsterdam: Rodopi, 1998.

Ricoeur, Paul. "La enunciación y el sujeto hablante”. Sí mismo como otro. Trad. Agustín Neira Calvo. España: Siglo XXI, 1996.

Robin, Regine. "La autoficción. El sujeto siempre en falta". Identidades, sujetos y subjetividades. Ed. Leonor Arfuch. Buenos Aires: Prometeo, 2002.

Rosa, Nicolás. El arte del olvido. Rosario: Beatriz Viterbo Editora, 2004.

\section{Estudios sobre el espacio en la literatura}

Aínsa, Fernando. "Aproximaciones al espacio literario desde la topofilia y la geopoéticas". Topografías literarias. El espacio en la literatura hispánica de la Edad Media al siglo XXI. Madrid: Editorial Biblioteca Nueva, 2017

Aristóteles, Física. Buenos Aires: Espasa Calpe, 1949.

Bachelard, Gaston. La poética del espacio. México: Fondo de Cultura Económica, 1965.

Bollnow, Otto Friedrich. Hombre y espacio. Barcelona: Editorial Labor, 1969.

Capel, Horacio. Dibujar el mundo. Borges, la ciudad y la geografía del Siglo XXI. Barcelona: Serbal, 2001.

Kant, Emmanuel. Crítica de la facultad de juzgar. Trad. Pablo Oyarzún. Venezuela: Monte Ávila, 1992.

Lotman, Yuri M. Estructura del Texto Artístico. $2^{\mathrm{a}}$ ed. Madrid: Istmo, 1982.

Merleau-Ponty, Maurice. Fenomenología de la percepción. México: Fondo de Cultura Económica, 1957. 


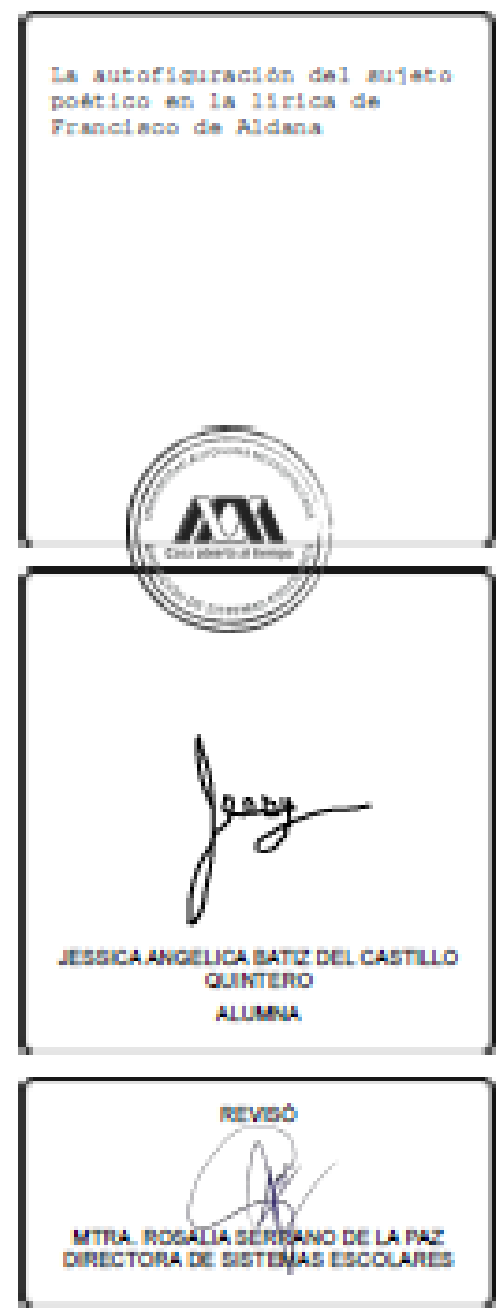

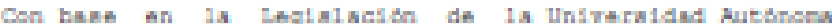
Metropolitana, an 1. Cludad de Maxieo an prasantaron a laA $17: 00$ horas del d5. 17 del mat de marzo del sto 2021 pOR

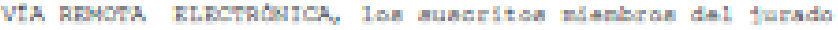
Sanignedo por is Consalón dal pongrado

DR, MARCGETO GRRAFTH GCWZAIRZ GARCTA

DR. JOREF nave cagkg GaY

MraA. hisa zartcta Masta coszatza

Ra1o 1. Pranidenas. dal prinaro $y$ eon carkctar da secretaria 1a ditima, we reventeron para proceder al Rxanon de Grado cuya denoninacion aparece al mareen, para la abtanes don dal grado of

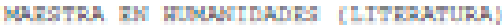

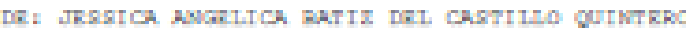

$y$ de meundo can al artieulo 70 fracessen III dal

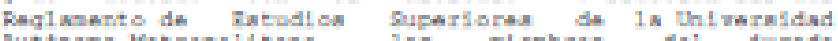

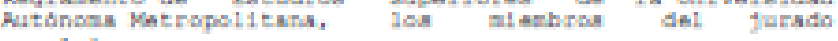
rasolvingen:

\section{APROBAR}

Reto continus, o1 prasidente del furado comunied a IA

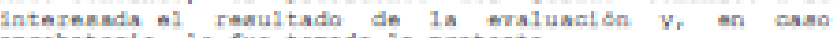
aprobatorio, Io fue tonada ia protenta.

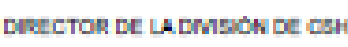

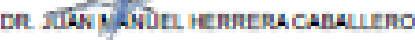
WOCAL

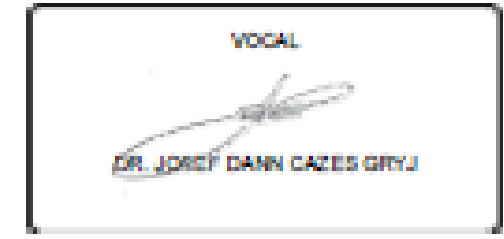

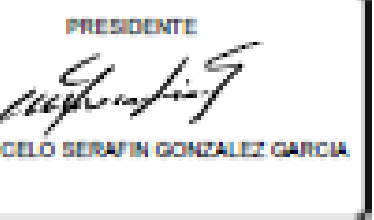

on Manctio strearis concrairz cancla

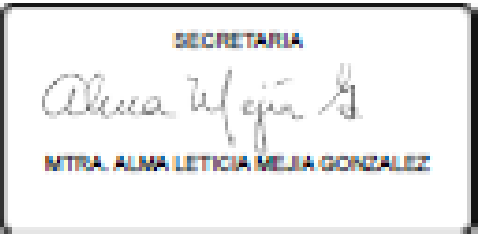

